International United Academy of Sciences

\title{
Scientific achievements of the third millennium
}

\author{
Collection of scientific papers \\ on materials \\ IX International Scientific Conference \\ 31.05.2019 г.
}

Part 4

\section{IJOURNAL.RU}

Washington 2019 
Scientific achievements of the third millennium. Collection of scientific papers, on materials of the IX international scientific-practical conference 31.05.2019 Pub. SPC "LJournal", 2019. - 104 p.

\section{SPLN 001-000001-0467-SA}

DOI 10.18411/scienceconf-05-2019-4

IDSP scienceconf-05-2019-4

The collection of scientific papers of the materials collected from different areas of scientific knowledge. This publication contains all the materials that were sent to the IX International scientific conference "Scientific achievements of the third millennium"

The collection is intended for researchers, teachers and students

All materials contained in the book, published in the author's version. The editors do not make adjustments in scientific articles. Responsibility for the information published in the materials on display, are the authors.

Information about the published articles will be transferred in the ELIBRARY.RU

The electronic version of the collection is available online scientific publishing center «Science Conf" Site center: science-conf.com

UDC 001.1

LBC 60 


\section{Соgержанше}

РАЗДЕЛ ХІІ. ЮРИСПРУДЕНЦИЯ 5

Клюшина А.А., Липская О.Н. Ювенальная юстиция как судебно - правовая система. 5

Kostenko D.S. Comparative analysis of genesis and evolution of jury trial in Russia and England....

РАЗДЕЛ ХІІІ. ПОЛИТОЛОГИЯ

Романов Ю.А. Российский федерализм: история и современность

РАЗДЕЛ ХІV. ЭКОНОМИКА

Абдуханова Н.Г., Войтович В.М. Формирование механизма финансирования реконструкции сложившейся застройки

Возиянова Н.Ю.,Доронина И.Е. Маркетинговая среда учреждения среднего профессионального образования и ее внешняя информационная составляющая. 23

Горский М.А. Параметрическая модель и результаты ее адаптации в деятельности российского коммерческого банка 28

Тесленко И.Б., Соловьева О.В. Новые тенденции в подборе и отборе персонала в условиях цифровизации.....

Третьяков О.В. Методика комплексной оценки корпоративной социальной ответственности российской компании

Усанова К.Д., Мищенко Е.А. Социально-экономическое устройство древнерусского государства

Хачемизов A.P. Бережливое производство как инструментарная подсистема контроллинга на предприятии . .56

Шаланина Н.А., Гординский Д.В. Унификация правил таможенного контроля в условиях цифровизации таможенного администрирования: зарубежный опыт ..... .59

Chernyh V.V., Nizova L.M., Suvorova A.P. Administrative barriers as a phenomenon of regulation of the market environment at the meso-economic level 62

РАЗДЕЛ ХV. МЕНЕДЖМЕНТ

Блинов С.В. Совершенствование системы управления персоналом в негосударственном учреждении здравоохранения 
Баранникова Т.Б., Казиахмедова С.X. Компаративные фразеологические единицы как средство формирования межкультурной компетенции в условиях полиэтнической среды.. 74

Гузанов Б.Н., Федулова К.А. Формирование критического отношения к информации при компьютерной подготовке студентов профессионально-педагогического вуза .......78

Кирюшина О.Н. Развитие и эффективное использование научной информации как основа интеграции научного и образовательного пространства. .81

Ланкин С.В., Иванюк Ю.О. Метапредметный подход в обучении астрономии .85

Belaya N.A., Rechitskaya E.G. Model of conditions for the formation of speech communication children with hearing impairment 88

Kozlova N.G. Sociocultural environment and its modeling in a secondary school 92

РАЗДЕЛ ХУІІ. ПСИХОЛОГИЯ

Магомедова А.Н., Бутаев Р.P. Изучение своеобразия эмоциональной сферы детей с интеллектуальной недостаточностью

Торебаев Б.П., Бектурсунова А.К., Ботабаев Н.Е., Ханазарова К.О. Функциональное значение цвета 99 


\section{РАЗДЕЛ ХІІ. ЮРИСПРУДЕНЦИЯ}

\section{Клюшина А.А., Липская О.Н. \\ Ювенальная юстиция как судебно - правовая система}

Международный юридический института

Одинцовский филиал

(Россия, Одинцово)

doi: 10.18411/scienceconf-05-2019-41

idsp: scienceconf-05-2019-41

\section{Аннотация}

Статья посвящена рассмотрению проблем, с которыми сталкиваются и могут столкнуться российские семьи при внедрении механизмов ювенальной юстиции.

Ключевые слова: дети, ювенальная юстиция, защита семьи, Семейный кодекс РФ.

\section{Abstract}

The article is devoted to the consideration of the problems that Russian families face and may encounter when introducing mechanisms of juvenile justice.

Keywords: children, juvenile justice, family protection, Family Code of the Russian Federation.

Обеспечение соблюдения прав и свобод несовершеннолетних является одним из приоритетных направлений государственной социальной политики.

Это предполагает признание за несовершеннолетними всей полноты социальноэкономических, политических, личных прав и свобод, закрепленных в Конституции Российской Федерации, международных договорах и иных нормативных правовых актах.

Специфическая деятельность федеральных, региональных и муниципальных органов, направленная на поддержание оптимального жизнеобеспечения семьи, детей и молодежи, являясь частью государственной политики, представляет собой ювенальную юстицию.

В России ювенальная юстиция - это судебно-правовая система, направленная на защиту несовершеннолетних.

Системой запланировано участие в делах несовершеннолетних граждан двух сторон: государственных органов и негосударственных учреждений, которые должны проводить проверку, реабилитацию и действия по исправлению поведения юных преступников. К непосредственным задачам органов ювенальной юстиции в России входит профилактика детской преступности, а также ряд социальных мер по защите детей в семьях.

Изначально ювенальная юстиция была задумана как система, органы которой будут работать для поддержки и защиты детей из неблагополучных семей.

Известный факт, что подрастающему поколению приходится нелегко получить хорошее воспитание в такой семье и стать полноценным членом общества в будущем.

Бороться и предотвращать действия родителей, направленных на угрозу жизни и здоровью ребенка - прямая обязанность органов ювенальной юстиции.

Перед общественностью стоит вопрос - выполняет ли система свое истинное предназначение в зарубежных странах, где она давно развита, и в России, где она в большей степени только зарождается.

Есть ряд негативных высказываний по отношению к действиям этой системы, потому что статистикой подтверждены данные, гласящие о росте количества самоубийств и разорений семей там, где ювенальная юстиция вмешивалась, имея целью спасти и защитить ребенка.

Поэтому остановить в нашей стране ювенальную юстицию, возможно лишь силами самих родителей. В том числе, с целью использования накопленного практического опыта борьбы с беззаконием на российском рынке детей. 
На сегодняшний день, понятие ювенальная юстиция трактуется как система организаций, мероприятий и всяческих реабилитационных программ, которые преследуют цель защиты прав и свобод несовершеннолетних.

Распространено 3 типа ювенальной системы:

- англо-американская. Основная цель - профилактика детской преступности. Содержит ряд мер, которые оказывают воздействие на ребенка, зависят меры от возраста ребенка и того, какое преступление он совершил;

- континентальная. Основная роль по исправлению возложена на судью, который выполняет роль не только непосредственно судьи, но также и соцработника, который помогает восстановиться пострадавшему;

- скандинавская. Включает работу с трудными подростками, ведущая роль в исправлении подростка возложена на соцработников. Случаи, когда нарушитель порядка лишается свободы, до совершеннолетия, редки.

По инициативе детского фонда ООН, международными специалистами было подготовлено специальное руководство для определения оценки показателей в области правосудия по отношению к малолетним.

Рамки правосудия в отношении детей характеризуются следующими показателями:

1. дети в заключении;

2. дети в предварительном заключении;

3. лишения свободы и санкции, связанные с этим;

4. специальная система правосудия по делам несовершеннолетних.

Ювенальная юстиция в России представляет собой судебно-правовую систему, деятельность которой заключается в защите прав несовершеннолетних.

Существует в России уже долгое время и является частью большей системы, включающей работу органов опеки и попечительства, комиссии по делам несовершеннолетних, работа по исправлению малолетних и т.д.

Регулируется деятельность уголовно-исполнительным кодексом, описывающим виды уголовной ответственности и способы отбывания наказания виновниками.

С 2000-х годов ведется ряд работ по внедрению ювенальной юстиции в Россию, но в упорядоченном виде.

Основанием для всех действий системы будет общая законодательная база.

Планируется организация деятельности следующих органов:

- правоохранительных;

- судебных;

- попечительских и сочиальных;

- учреждений, ведущих просветительскую деятельность;

- реабилитационных учреждений.

Так, первый ювенальный суд в России был создан в 2004 году. Цель рассматривать дела по правонарушениям детей (до наступления совершеннолетия).

Несмотря на то, что первоочередные мероприятия - это оказание психологической помощи и реабилитационные действия, они не проводились.

Данные, представленные на 2018 год, свидетельствуют о том, что в России 11 составов судей, занимающихся только правонарушениями несовершеннолетних. Представлены в различных регионах РФ.

Среди причин злоупотреблений правоприменителей, являющихся системными, а не случайными, можно отметить следующие:

1. Созданный в России «рынок» детей и высокий спрос на детей, который порождает корыстную заинтересованность в «передаче детей в семью» или в постановке семьи на обслуживание;

2. Заинтересованность в наполнении организаций для детей-сирот и детей, оставшихся без попечения родителей (различных некоммерческих организаций (НКО): реабилитационных центров, Центров содействия устройству детей и др.), имеющих подушевое финансирование;

3. Непродуманные показатели работы социальных служб: 
- заинтересованность (доплата) в объеме выявления неблагополучия приводят к излишнему рвению;

- объединение противоположных функций в единое ведомство приводят к конфликту интересов.

4. Незнание законов:

a) подмена законов сложившимися обычаями;

б) неразличение видов неблагополучия и их правовых режимов:

- «антисанитария»;

- «ненадлежащее выполнение обязанностей»;

- «невыполнение обязанностей»;

- «социально опасное положение»;

- «непосредственная угроза жизни и здоровью» при игнорировании слова «непосредственная»;

в) игнорирование родительского права (ст. 63, ст. 68 Семейного кодекса РФ) в пользу перестраховки.

5. Профессиональная деформация - неправильные психологические установки в отношении к семьям:

- установка на защиту детей вместо защиты семьи в целом;

- установка, что нужно найти ребенку родителей «получше».

6. Новые технологии социальной работы, созданные на гранты ювенальных фондов, не соответствующие законодательству.

Эти технологии аморальны и приносят страдания людям.

Виды злоупотреблений

1. Процесс выявления семейного неблагополучия

Сотрудники опеки чаще всего (по неграмотности или не считая нужным соблюдать закон) не различают виды неблагополучия и виды его выявления выявление социально опасного положения (ст. 13 Федерального закона от 24.06.1999 N 120-Ф3 «Об основах системы профилактики безнадзорности и правонарушений несовершеннолетних») и выявление детей, оставшихся без попечения родителей (ст. 122 ч. 1 Семейного кодекса РФ).

В силу этого органы опеки участвуют в первом виде выявления, который не входит в их полномочия.

2. Процесс захвата детей:

А. Органами полищии по Федеральному закону от 24.06 .1999 N 120-ФЗ «Об основах системы профилактики безнадзорности и правонарушений несовершеннолетних»:

1). Сотрудники Подразделения по делам несовершеннолетних органов внутренних дел (ПДН) забирают с улицы не только безнадзорных (ст. 1 Федерального закона от 24.06.1999 N 120-ФЗ «Об основах системы профилактики безнадзорности и правонарушений несовершеннолетних», где указано - «контроль за поведением которого отсутствует», «вследствие ненадлежащего исполнения обязанностей»).

Иногда очевидно, что сотрудники неправильно понимают, что значит «безнадзорный».

Например, распространено объяснение «находился без законного представителя» (в том числе под это определение подпадают гуляющие на улице дети или даже подростки по дороге из театра).

2). Забирают из дома, когда безнадзорность ни при чем, то есть в присутствии членов семьи, при отсутствии доказательств ненадлежащего исполнения родителями своих обязанностей, нередко фальсифицируя документы:

a) по признакам социально опасного положения, хотя это только основание для индивидуально-профилактической работы, а не для отобрания детей;

б) по субъективному ощущению неблагополучия, когда нет даже признаков социально опасного положения: например, если в доме беспорядок, родители выпившие, и т.П., то есть, когда нет оснований говорить о непосредственной угрозе жизни и здоровью ребенка; 
в) по основаниям, отсутствующим в законодательстве, но взятым из методичек, несущих собственную, не узаконенную идеологию (и это нарушает требование ст. 8 Федерального закона от 24.06.1999 N 120-Ф3 «Об основах системы профилактики безнадзорности и правонарушений несовершеннолетних» о необходимости соблюдения Конвенции о правах ребенка; служащие отделов ПДН словно не знают, что согласно ст. 21 ч. 1 п. 1 Федерального закона от 24.06.1999 N 120-Ф3 «Об основах системы профилактики безнадзорности и правонарушений несовершеннолетних», неисполнение родителями обязанностей требует от сотрудников проведения с ними профилактической работы, а не изъятия детей);

г) проникают в дом, не глядя на несогласие жильцов, без должных оснований, без судебного постановления, в нарушение ст. 165 ч. 5 Уголовно-процессуального кодекса РФ, со взломом дверей (в таких случаях усматриваются признаки преступления, предусмотренного частью 3 ст. 139 Уголовного кодекса РФ «Нарушение неприкосновенности жилища, совершенные лицом с использованием своего служебного положения»; однако уголовные дела следственными органами не возбуждаются);

д) с применением физической силы к родственникам и опекунам;

ж) без разъяснения законным представителям несовершеннолетних их прав, предусмотренных Кодексом об административных правонарушениях РФ;

3) с применением психологического воздействия на родителей - вторжение в квартиру с автоматчиками, удержание на руках вытащенного из постели ребенка до тех пор, пока родитель не подпишет требуемые документы.

Б. Опекой по ст. 77 Семейного кодекса РФ:

1) забирают не по постановлению главы администрации;

2) не оставляют Акта изъятия;

3) причина отобрания - не «непосредственная угроза», а просто неблагополучие, которое должно влечь или социальную помощь, или рассмотрение в Комиссии по делам несовершеннолетних и защите их прав (КДНиЗП) по ст. 5.35 Кодекса об административных правонарушениях РФ;

4) неправильно оформляют документы при проведении плановых и внеплановых осмотров мест проживания несовершеннолетних;

5) нередко фальсифицируют документы, отражая в актах обстоятельства, не соответствующие действительности, применяя оценочные определения, не регламентированные законами и подзаконными актами, такие как: «кошмарное состояние жилого помещения», «ужасная грязь в квартире, беспорядок», без расшифровки отмеченного, при этом «антисанитария» не подтверждается заключениями «санэпиднадзора» и чаще всего означает отсутствие ремонта в жилом помещении;

6) расширительно толкуют понятие «угроза жизни и здоровью» несовершеннолетнего», позволяющее изымать детей по надуманным основаниям.

3. Заключение детей в медицинское учреждение:

1). Согласно ст. 18 Федерального закона от 24.06.1999 N 120-Ф3 «Об основах системы профилактики безнадзорности и правонарушений несовершеннолетних», больницы должны принимать заблудившихся, подкинутых, оставшихся без попечения. На практике же больницы принимают всех, кого привезет полиция, даже если за ними идет плачущая мать, то есть в ситуации, когда статус «оставшийся без попечения» ребенку еще не мог быть присвоен.

2). Как правило, это инфекционная больница, в которой запрещают посещения, ссылаясь на режим, не разрешают родителям и законным представителям оставаться в медицинском учреждении вместе с несовершеннолетними, нуждающимися в постоянном уходе, вопреки Федерального закона от 21.11.2011 № 323 «Об основах охраны здоровья граждан в Российской Федерации».

3) Администрация медицинских организаций не отдает детей родителям по их требованию даже по окончании «лечения» или в случае отсутствия необходимости в стационарном лечении (ст. 68 Семейного кодекса РФ), отсылая в опеку.

4. Непередача детей под предварительную опеку родственникам

При изъятии детей обычно даже не рассматривается вопрос о целесообразности временного назначения опекуна или попечителя (тем более из числа родственников) 
вместо помещения ребенка в организацию для детей-сирот (ст. 12 Федерального закона от 24.04.2008 N 48-Ф3 «Об опеке и попечительстве»).

5. Невозвращение опекой детей родителям по их требованию (ст. 63, 68 Семейного кодекса РФ):

1). После отобрания ребенка, статьи 63 и 68 Семейного кодекса РФ на практике не работают.

Органы опеки родителям выдвигают незаконные требования: собрать документы для возврата детей - «справки о благополучии», то есть об условиях проживания и уровне достатка, прописке, «белой» зарплате и пр. На основании справок сама опека дает или не дает заключение о целесообразности соблюдения закона.

2). В случае подачи опекой заявления в суд на лишение родительских прав отказываются вернуть детей родителям до суда, хотя фактически родители являются законными представителями своих детей, не лишенными по решению суда родительских прав.

6. Отсутствие реабилитационной работы с семьей:

Для лишения прав, согласно постановлению Верховного суда РФ от 27.05.1998 № 10 «О применении судами законодательства при разрешении споров, связанных с воспитанием детей», необходимо, чтобы были исчерпаны все меры для реабилитации семьи.

Чаще всего опека никаких мер не предпринимает или формально направляет родителей в какую-нибудь НКО для проведения с ними непонятно, какой работы.

7. Поспешное присвоение статуса «оставшийся без попечения»:

1). Устройство ребенка в приемную семью происходит без вынесения постановления органа опеки о признании ребенка оставшимся без попечения и до лишения родителей родительских прав.

2). При присвоении статуса оперируют тем, что мать ребенка «не забрала из учреждения», тогда как закон требует, чтобы она «отказалась забрать из учреждения». При этом мать бывает вполне доступна и даже хочет вернуть ребенка себе.

Фактически эта процедура является внесудебным лишением родительских прав, так как ею опека присваивает себе право устраивать ребенка по своему усмотрению.

8. Передача под опеку (в т.ч. в приемную семью) ребенка, чьи родители не лишены прав:

1) передаются дети, чьи родители не лишены судом родительских прав и хотят воспитывать ребенка;

2) не отрабатываются родственные связи;

3) не отрабатывается приоритет усыновления перед опекой (ст. 124 ч. 1 Семейного кодекса РФ).

9. Выходы «на адрес» по доносам:

Родители обвиняются в уголовном преступлении (жестоком обращении) не в уголовно-процессуальном порядке, а на основе методичек, несущих неузаконенную в РФ идеологию и терминологию («эмоциональное насилие», «психологическое насилие»).

10. Со стороны сотрудников детских учреждений, системы профилактики безнадзорности правонарушений и преступлений, таких как детские дома и приюты, отмечены следующие нарушения:

1) запрещение свиданий с родителями, не лишенными родительских прав, другими близкими родственниками;

2) помещение анкеты ребенка, родители которого не лишены родительских прав, в федеральную базу со статусом «возможно усыновление»;

3) оформление документов для иностранного усыновления при наличии кровных родственников, проживающих на территории Российской Федерации;

4) удержание подростков в стенах приютов, несмотря на их желание покинуть приют и вернуться в семью;

5) отсутствие своевременных проверок семей опекунов.

11. Со стороны опекунов (не из числа родственников) установлено злоупотребление своими правами:

1) использование детского труда;

2) вовлечение в преступную деятельность. 
Таким образом, подводя итог вышеизложенному, можно сделать вывод, что работникам опеки выгоднее отбирать детей, чем разбираться в их проблемах

Школьные учителя скоро будут ставить оценки не только детям, но и взрослым.

Так, например, в Пермском крае, комиссия по делам несовершеннолетних выступила с инициативой введения балльной оценки неблагополучности семей.

А раздавать штрафные баллы должны будут школьные учителя.

Впрочем, Пермский край тут вовсе не исключение: ювенальщики уже давно превратились в ночной кошмар родителей по всей стране.

В настоящее время нет чёткой формулировки самого термина неблагополучности семей. Признаки неблагополучия фиксируются при посещении семьи в акте обследования жилищно-бытовых условий. При этом акт составляется без участия самих родителей.

Парадокс, но сегодня те, кто вообще-то должен защищать детей и помогать семьям в трудной жизненной ситуации, напротив, превратились в их главных врагов.

В конце 2016 года в Новосибирске прогремела история многодетной семьи, которую буквально терроризировали органы опеки, угрожая забрать детей.

Оказалось, что «кошмарить» семью стали из-за того, что у главы семейства возникли разногласия в бизнесе с одним из бывших сотрудников полиции. Старые связи полицейского сделали своё дело.

Ситуация развивалась по классическому сценарию: ювенальщики явились в дом, начали составлять акт обследования жилищных условий и угрожать тем, что дети будут перемещены в распределительный центр.

Подобных историй по стране сегодня великое множество.

В Санкт-Петербурге второклассника почти месяц содержали в специализированном учреждении только потому, что мальчик, придя домой из школы, не застал родителей дома и гулял на улице. Вечером органы опеки явились к ребёнку домой и забрали его на глазах у родителей. Прошло несколько недель, прежде чем мать наконец-то смогла убедить «ювеналов» в том, что никаких признаков неблагополучия в семье нет.

Другой случай произошёл в Московской области, где органы опеки забрали шестилетнюю девочку прямо из детского сада.

Приёмную мать при этом даже не поставили в известность. «Ювеналы» сработали «по наводке» заведующей детсадом, которая сообщила, что девочка ведёт себя слишком пассивно и что у неё на руке синяк. В итоге девочка была разлучена с матерью почти на два месяца. При этом родителям даже не позволяли видеться с ней.

Кстати, по статистике новосибирских общественников, до $30 \%$ обращений в органы опеки - это «доносы» сознательных граждан, соседей, учителей и т.п.

На сегодняшний день, сама система сегодня выстроена таким образом, что органы опеки фактически заточены на то, чтобы как можно чаще изымать детей из семей.

Так что все «доносы» проверяют с особым пристрастием.

Распределительные центры, куда перемещают детей, - это бывшие детдома. А у них подушевое финансирование. Если детей нет, то их разгоняют.

Кроме того, сегодня в России процветает бизнес на приёмных семьях.

Нередки случаи, когда приёмные родители специально чуть ли не по всей стране собирают детей, с тем чтобы потом поселиться в регионе, где на детей выплачивается хорошее пособие, а родителям полагаются «богатые» социальные льготы.

Так, например, в Кемеровской области сейчас есть большой спрос на детейинвалидов. Потому что за них полагаются хорошие выплаты. Между тем уже известны случаи, когда приёмные дети умирали и эти факты скрывались.

Возникает ощущение, что работникам опеки легче «принять меры» и изъять ребёнка из семьи, чем разбираться в ситуации и помогать семье восстановить нормальную атмосферу.

Сложившаяся система отношений: орган опеки - образовательное учреждение семья (родители и дети) настроена только на то, чтобы не допустить тяжких последствий для детей.

Поэтому, как только возникают подозрения в неблагополучии семьи, вместо того чтобы заняться мониторингом семейных отношений, сначала изымают детей из 
семьи, а уже затем проводят проверку, результаты которой нередко выглядят необъективными.

В таком случае, это уже не политика защиты детей - это уже бизнес.

И если мир делится на черное и белое, а бизнес на чистый и грязный - можно поспорить на что угодно: «ювенальный бизнес» быть чистым не может.

Когда на одной чаше весов ребенок, а на другой деньги - родная семья оказывается «третьей лишней».

Что может быть страшней в стране, которую мы все еще называем демократической?

$$
* * *
$$

1. Конвенция о правах ребенка (одобрена Генеральной Ассамблеей ООН 20.11.1989) (вступила в силу для СССР 15.09.1990).

2. Конституция Российской Федерации (принята всенародным голосованием 12.12.1993) (с учетом поправок, внесенных Законами РФ о поправках к Конституции РФ от 30.12.2008 N 6-ФКЗ, от 30.12.2008 N 7-ФКЗ, от 05.02.2014 N 2-ФКЗ, от 21.07.2014 N 11-ФКЗ).

3. Кодекс Российской Федерации об административных правонарушениях от 30.12.2001 N 195-Ф3 (ред. от 18.03.2019) (с изм. и доп., вступ. в силу с 29.03.2019).

4. Семейный кодекс Российской Федерации от 29.12.1995 N 223-Ф3 (ред. от 18.03.2019).

5. Уголовный кодекс Российской Федерации от 13.06.1996 N 63-ФЗ (ред. от 27.12.2018) (с изм. и доп., вступ. в силу с 08.01.2019).

6. Уголовно-процессуальный кодекс Российской Федерации от 18.12.2001 N 174-Ф3 (ред. от 06.03.2019).

7. Федеральный закон от 24.06.1999 N 120-Ф3 (ред. от 27.06.2018) «Об основах системы профилактики безнадзорности и правонарушений несовершеннолетних».

8. Федеральный закон от 24.04.2008 N 48-Ф3 (ред. от 03.08.2018) «Об опеке и попечительстве».

9. Федеральный закон от 21.11.2011 N 323-Ф3 (ред. от 06.03.2019) «Об основах охраны здоровья граждан в Российской Федерации».

10. Постановление Пленума Верховного Суда РФ от 27.05.1998 N 10 (ред. от 26.12.2017) «О применении судами законодательства при разрешении споров, связанных с воспитанием детей».

\section{Kostenko D.S. \\ Comparative analysis of genesis and evolution of jury trial in Russia and England} Law School of Siberian Federal University (Russia, Krasnoyarsk)

doi: 10.18411/scienceconf-05-2019-42

idsp: scienceconf-05-2019-42

\section{Abstract}

The foundation of the institution of trial by jury was not laid in any act of the legislature, but it arose silently and gradually out of the usages of a state and society. There are various and conflicting opinions expressed by historians and writers as to the origin of this institution. Jury procedure permitted much of the work in judication deciding contest cases to ordinary citizens persons untrained in the law. In England the challenges of operating a jury based procedures system have exercised a shaping influence on match of the legal system. Across the centuries jury trial underwent incessant change and was adopted in different legal systems across the world, particularly in Russia.

Key words: history, jury trial, judicial system, jury board, justice.

The jury system was develop In XII-XIII centuries of history of England. It refers to the period, when the Crown took the steps that committed the common law to jury based procedure. Juries in this period were called self-informing. Jurors were drawn from the closest vicinity of the events in dispute in the expectation that at least some of them would already know something about the facts or at least be well positioned to find out. They are also described as "a man chosen as being likely to be already informed" [1]. They were expected to form their verdict and more often come to court to speak, then to listen.

Most people lived in largely self-sufficient villages that were engage in a particular substance of agriculture. Working on the open field system, the villagers pulled their labor, they 
worked collectively on each other's land, presumed to a communally administrative program of plowing, planting, harvesting. The policing function in these communities was also communal, because the able body males of the village were organized in the policing groups for responding to attacks on personal property. This form of social organization led to a very high levels of social interaction.

The power implication of early jury system is impressive. On the one hand being a juror was not a welcome experience - the crown had coursed you to take on an unpleasant morally troublesome work of setting the judgment on the life and affairs of your neighbors. On the other hand jury procedure entailed a significant component of power sharing, because the system placed the power of the judication in the hands of these citizens groups.

The roots of the failure of the government in organizing the effective system of evidence gathering is to be found in the early conception of jurors as bearers of the knowledge needed to resolve disputes. By assuming that the jurors had already knew the facts, the jury system defaulted on the central task of the system. Moreover, jury system was not organized to probe witness testimony which is in modern understanding a sort of evidence that is essential for rational judication.

The self-informant jury system was declined in XIV-XV centuries, so the different conception of jury trial came to prevail. Jury trial system changed function and became primarily in occasion of educating the jurors about the facts. This phase may be called as instructional trial.

In a much elaborating form, this conception of a jury trial endeavors to modern day. The emergence of instructional trial supposes that the work of gathering and presenting evidence would be assumed by the persons other than the jurors.

The Black Death, which struck in 1349 , led to the huge population losses. This lead to new tendency of labor mobility that left old style agrarian villages no longer viable. Because of this, jurors start to be drawn from the county wide pool who's members were far less likely able to collect knowledge's about the dispute.

In criminal cases the shift to jury ignorant of the facts, posed a significant investigative challenge. In the era before professional police forces or prosecutorial corpse who would gather and present criminal evidence to the jurors, the initial response was to place heavy reliance on the victim who also called victim-prosecutor. By the middle of the XVI century the Crown took the steps to have a public officer assist the victim in pre-trial and trial procedure. But the investigation regime came with the investigation defect on its own - a one sidedness that would generate accusing evidence only.

To the XVIII century the shift from the self-informing jury to the instructional trial affected the change of power balance, what have been near the monopoly of knowledge about the facts of the case. The judge found himself learning the evidence of the case at least as well as the jurors. That development enabled the judge to exercise greater influence over the jury. The functional reality was that the judicial comment allowed the judge to influence the jury's verdict.

By the XIX century "Jurors in general follow the advice of the judge and therefore the substance of the verdict is found by the judges direction. Closely connected to judicial comment on the evidence was the extensive power that the judge is developed to instruct jurors or what the judge chose to characterize as issues of law. Instructions of this sort commonly dealt with what inferences jurors should draw from particular fact pattern. This technique of recasting fact issues as questions of law, subject to judicial instruction, resulted in a stain narrowing in the jurors sphere of responsibility for fact finding process.

Rule of hearsay or the confession rule provided trial judges with still further power to decide what sorts of evidence the jurors would be allowed to study. The jurors were expected by the trial judge to disclose the thinking lead them to the verdict that supposed to render. Having learned the basis for the verdict the trial judge could refuse to accept it, instruct the jurors further and send them back to deliberate it again.

Jurors power was nominally respected by granting the party who loss the trial with the right to have the case retried to another jury. In this way a new trial downplayed the question of the initial verdict. If the judge who tried the cause declare himself satisfied with the verdict it have been usual not have grand a new trial. On the other hand if the judge declares dissatisfied with the verdict it is pretty much the cause of a new trial. Another words, jury control weakened the jury authority [2]. 
The development of civil justice seriously affected on the trial proceedings in a whole. In XIX century jury trial was inseparable, there was no such thing as non-jury trial in a common law civil case.

The transformative development in criminal justice of XIX-XX centuries has been an emergence of professional policing and prosecution emergence of vast expansion. This development finally succeeded in overcoming the investigation deficit that has humbled jury based criminal justice across the prior centuries. The prosecutor that was expected to propel the criminal trial in former times has today become simply a witness in a state run prosecution based on police generated evidence. Professional policing and prosecution brought improvements in quality and quantity of criminal evidence. Professionalization of the work of criminal investigation led to professionalization of charging function that is formulating the official criminal charge.

The ancient grand jury historic route of the jury tradition became obsoleted and was abolished by legislation in 1933. Since the late XVIII century legislation expanded range of summary offences, the early XIX century movement to ameliorate this criminal law resulted in extensive statutory classification and downgrading capital crimes trialed by jury (such as arson), which became triable by the magistrates. Thereafter, new offences, in economics for example, have increased the role of summary jurisdiction.

Criminal jury trial has changed character in many ways since the days of self-informing jury, but one great constant is that now as then jury trial defuses the judicative power away from officialdom. There always be cases in which from the nature of events or the persons involved officialdom seems compromised appear compromised and that is why criminal jury trial although greatly diminished continues to survive at least for now.

The concept of the system of jury trial was spread among the world, so the legal systems of different countries adopted it in accordance to the specific national features. It is crucial to mention, that the fundamental elements of the jury trial were established in the Russian legislation long before the complete system of Russian jury trial was adopted. Thereby, the legal code of Kievan Rus' (Russkaya Pravda) mentioned that a person accused of larceny, but who have been denying his/her guilt, should appear before 12 man, who are able to decide the question of guilt.

To the end of XVIII century the idea of adaptation of jury trial in Russia become very topical, especially in contrast to the progressive judicial standards of Western Europe.

With the judicial reform of 1864 jury trial was completely set as an independent legal institute in Russia. The main goal of the reform was to provide trust in decision of the judge, so that trust will provide stability of the state and steadiness of the court's decision [3].

Russian jury trial has unique and comprehensive way of its evolution, which is significantly differs from the foreign countries and England in particular. This contradiction mainly caused by the turning points of Russian political history, consequently, there are more formation periods to describe.

After the above mentioned period of great reforms of 1864, in which jury system was created, the reverse process of counter reforms was initiated. It started in 1870 and was concluded in decreasing the amount of rights of the jurors and their jurisdiction in criminal procedure.

However, despite of this by the beginning of the XIX century the jury system was stabilized and decisively adopted as a part of the justice mechanism. Jury trial even passed the verdicts in the period of World War I, although the military situation often limits the activities of democratic institutions [4].

The period of 1917-1950 marked by the adoption of the decree "On Court" which banned the institution of jury trial. The absence of jury was until the $1980 \mathrm{~m}$ when the Soviet Government adopted the law "On approval of the Fundamentals of Legislation on the Judicial System of the USSR and Autonomous Republics". This law set the rule of consideration of all cases in the court of first instance with the representatives of general public alongside with the professional judge.

In modern Russia, the right of citizens "in the administration of justice" is enshrined in part 5 of article 32 of the Constitution of the Russian Federation. Jury trials are carried out on the basis of the Criminal Procedure Code and the federal law "On jury assessors of federal courts of general jurisdiction in the Russian Federation" dated August 20, 2004. Criminal cases involving jurors are considered in the Supreme Court of the Russian Federation, the supreme courts of the 
republics, regional, regional, district courts, courts of cities of federal significance, and district (naval) military courts. Moreover, from June 1, 2018, the jury institute is introduced in district courts and garrison military courts.

Despite the differences political history and differences in judicial system there are common parts in the process of the formation of jury trial in Russia and England. Although Russian jury trial was adopted much later than in England, the essence of administration the justice by people unqualified in law had a positive impact on the judicial system and society. Both countries faced a problem of reducing the jury competence, at the same time paying tribute to the division of powers of the judiciary and the development of democratic institutions.

$* * *$

1. James Bradley, A preliminary treatise on evidence at the common law pp. 47-84. 1898.

2. John Langbein (2015) The four epochs of jury trial in England [audio lecture] // https://soundcloud.com/britishacademy/the-four-epochs-of-jury-trial-in-england/s-VAI6Z.

3. Зарудин, С.И. Общие соображения о составе суда: Материалы. Т. 17. СПб., 1879.

4. Ифланд П.А. Присяжные заседатели и война // ЖМЮ. 1917. №5. С.214. 


\title{
РАЗДЕЛ ХІІІ. ПОЛИТОЛОГИЯ
}

\author{
Романов Ю.А. \\ Российский федерализм: история и современность \\ Восточно-Сибирский государственный университет технологий и управления
} (Россия, Улан-Удэ)

doi: 10.18411/scienceconf-05-2019-43

idsp: scienceconf-05-2019-43

\section{Аннотация}

Статья рассматривает проблемы федерализма, в ретроспективном описание от прошлого к настоящему. Проблематика рассматривается посредством примеров о том, что Россия, является государством, в котором уживаются по сути диаметрально противоположные признаки, такие как унитарность государства, так и федерализм. Описываются примеры соотнесения национального вопроса с жесткой унитарной системой построения государства. Особенно ярко, это просматривается на уровнях как культурного, так и иного развития всех тех, территорий, что входили и входят в состав России, что в свою, очередь приводят к росту конфликтности сохранения национальных, культурных и иных ценностей. Федерализм в его практической реализации на примере России, способствовал сохранению единства и территориальной целостности, несмотря на пагубность примера развала СССР в 1991 году.

Ключевые слова: федерализм, идеи о самоуправлении, многонациональное государство, национально-культурной автономии, национальный вопрос, федеративных отношениях, взаимоотношения между федеральным центром и регионами, федеративным устройством.

\section{Abstract}

The article considers the problems of federalism, in retrospective description from the past to the present. The problem is considered by means of examples that Russia is a state in which diametrically opposed features, such as the unitarity of the state, and federalism coexist. Examples of the correlation of the national issue with the rigid unitary system of building a state are described. Particularly vividly, this is seen at the levels of both cultural and other development of all those territories that were and are part of Russia, which in turn, leads to an increase in the conflict of preserving national, cultural and other values. Federalism in its practical implementation on the example of Russia, contributed to the preservation of unity and territorial integrity, despite the pernicious example of the collapse of the USSR in 1991.

Keywords: federalism, ideas about self-government, multinational state, nationalcultural autonomy, national question, federal relations, relations between the federal center and regions, federal structure.

Федерализм и его практическое осуществление в современной России находится на стадии своего становления и по сути взросления. Это обусловлено, прежде всего, тем, что у России как государства, построенного на принципах федерации нет собственного опыта подлинных федеративных отношений: большую часть своей истории Россия «деюре» (до 1918 г.) или «де-факто» (в советский период) была унитарным, централизованным государством. Тем не менее, элементы федерализма в России были.

Идеи об самоуправлении закреплялись еще в «Русской Правде» (X - XI веков), Новгородской и Псковской судных грамотах (XII - XIII веков), Судебниках 1497 и 1550 гг., Соборном уложении 1649 г., актах Петра I и т. п. В процессе расширения Российской империи входящие в состав России народы и территории (княжества, ханства, царства, губернии и пр.) сохраняли возможность самоуправления и достаточно широкую степень автономии. 
В проектах конституции декабристов (XIX век) уже содержались вполне оформленные идеи и концепции федерации («республика многонациональной федерации славянских и некоторых соседних государств Центральной и Южной Европы», «конституционная монархия, состоящая из федеративных территорий» и т. п.), а по сути, повторения пути Швейцарской Конфедерации.

Как обустроить многонациональную Россию?»- этот вопрос на протяжении всей истории нашей страны неоднократно поднимался. Кроме того, за последние три столетия существует устойчивая тенденция постоянного процесса реорганизации Российского государства. Одна из первых попыток решения национального вопроса относится, очевидно, ко времени работы уложенной комиссии Екатерины II в 1762 - 1763 годах. Тогда представители Украины, поддержанные Ливонскими и Эстляндскими депутатами, обратились к императрице с просьбой более подробно рассмотреть во время работы комиссии национальные особенности различных регионов России. На, что она ответила им отказом, пояснив, что лучшим средством для достижения «общего блага» подданных должна стать их русификация. Правительство считало своей важнейшей задачей поддержание национального единства, поэтому любые претензии к национальной обособленности было воспринято как прямая угроза территориальной целостности [1]. Аналогичные процессы происходили и в истории других стран.

Россия как государственное объединение изначально было построено как многонациональное государство, в котором вместе живут разные народы. В отличие от других империй, Россия, присоединив территории, не подвергала население дискриминации, ни один, даже самый малый народ в стране не исчезли как этнос, как общность людей, имеющих свой язык, свою культуру, свои религиозные воззрения.

Так в Российской империи отсутствовало перманентное государственное регулирование общественной жизни. Однако это не свидетельствует, что в ней России не были национальные проблемы. Постепенно увеличивая тенденцию к централизации и унификации, были отобраны права на автономных территориях с особым статусом. Тем не менее, до второй половины XIX века национальные движения в России были слабы или же находились в состоянии своего возникновения. Первоначально они были ориентированы только на защиту национальной культуры и языка (как реакция на проведение в этот период насильственной русификации). На рубеже XIX - XX веков появляются требования о национально-культурной автономии, и только в начале XX века возник лозунг «права Наций на самоопределение» [2], который был подхвачен пришедшими к власти в 1917 году большевиками. После прихода их к власти, произошло, решительное отмежевание, а по сути отказ от политики царского правительства в решении национального вопроса. Они были убеждены, что уничтожение частной собственности постепенно приведет и к отмене национальных различий. Эти взгляды были приняты ими из марксистской доктрины. Национальный характер, писал Энгельс, «смешаем и так исчезнет, как только исчезнут всякие сословные и классовые различия» [3].

При создании в 1922 году, территориально-провинциальная Советская Россия, РСФСР была заменена системой Федерального государства. Несмотря на это, СССР был формальным федеративным государством с элементами Конфедерации, так как было провозглашено «право Наций на самоопределение вплоть до отделения». На деле же, государство было унитарным с твердой, по сути жесткой направляющей ролью Коммунистической партии. Этот федерализм был своеобразной политической технологией, о чем свидетельствует тот факт, что большинство автономных регионов Российской Федерации (как и в ряде республик СССР), в которых коренная нация составляла большинство населения - республики Средней Азии, Закавказья, Прибалтики, Украина, были в более привилегированном положении по кадровой, промышленной, культурной политике. Среди особенностей Союза ССР следует выделить, следующее можно было обойтись без национальной государственности русского народа. Попытки 
исправить эту ситуацию, предпринятые в 1923, 1925, 1927, 1949 года, ни к чему не привели из-за отсутствия государственной политики решения данного вопроса. Система «Pseudophedrine» СССР позволило центру свободно доминировать.

В результате, русский народ за годы Советской власти оказался по сути приватизирован в большей степени, чем многие другие народы страны. Он был опорой государства и, сохраняя внешние атрибуты величия и доминирования - наименование «большой брат», доступ к власти и управления в центре и на местах, больше возможностей для языкового развития, заплатил за это страшную цену. Двойной статус - с одной стороны, он являлся ядром системы, с другой стороны, был ее главной жертвой. Его статус не совсем ясен и по сей день: то ли это все-таки «большой брат» или он будет служить своего рода «цементирующим элементом» по укреплению новой исторической надэтнической общности - российский народ.

На протяжении всей истории понятия «Россия», «Российская империя», «СССР», это действительно означает то же самое. И, так, после распада СССР в 1991 году начался сложный и болезненный процесс становления российской государственности в новых территориальных границах (границах 1600 - х годов), в других геополитических, экономических и прочих условиях. Данный процесс был, обременен ростом национального самосознания народов, создание суверенных республик в составе России. В некоторых автономных образованиях активизировались националистические, сепаратистские настроения, что по сути угрожали единству Российского государства.

После распада СССР в 1991 г. стал вполне реальным и распад Российской Федерации на составные части по национальному и административному признаку.

В значительной степени данный исход был предотвращен заключенным 30 апреля 1992 года Федеративным договором. Данный договор, представлял собой фактический синтез трех договоров о разграничении предметов ведения и полномочий между федеральным центром и группами субъектов федерации: во-первых, республиками; вовторых, краями, областями, городами федерального значения; в-третьих, автономной областью и автономными округами. Однако он не мог разрешить все негативные тенденции в российских внутри федеративных отношениях, прежде всего потому, что закреплял неравноправие различных субъектов федерации, а это не могло удовлетворить представителей большей части субъектов - краев и областей. Договор подписали не все регионы, в частности, Татарстан, Чеченская Республика, многие субъекты РФ подписали его с оговорками.

Дальнейший ход развития федеративных отношений в России решается на основе действующей Конституции РФ 1993 г. и системы взаимоотношений, выстраиваемых и выстраивающихся на взаимовыгодных отношениях между федеральным центром и регионами с учетом, как исторических традиций страны, так и опыта стран мира с федеративным устройством.

\section{***}

1. Барсенков А.С. Русский вопрос в зеркале истории // Русская нация: историческое прошлое и проблемы возрождения. М., 1995.

2. Смирнов А.Ф. О социальной основе национальных движений в России в ХІХ в. М., 1969.

3. Маркс К., Энгельс Ф. Соч. 2-е изд. Т.42. С.360. 


\section{РАЗДЕЛ ХІV. ЭКОНОМИКА}

\section{Абдуханова Н.Г., Войтович В.М. \\ Формирование механизма финансирования реконструкции сложившейся застройки}

Казанский Архитектурно-строительный Университет (Россия, Казань)

doi: $10.18411 /$ scienceconf-05-2019-44

idsp: scienceconf-05-2019-44

Актуальность исследования обусловлена практической значимостью реновации в жилищной сфере в виде основы формирования качественной и благоустроенной жилой среды для населения.

Целью исследования является теоретическое обоснование и расчет методического подхода к формированию механизма финансирован капитального ремонта на примере Ямало-Ненецкого автономного округа. Для достижения этой цели необходимо решить следующие задачи: изучение практики проведения капитального ремонта в ЯНАО для выявления основных проблем, анализ жилого фонда, анализ предложенных мероприятий с использованием статистических данных на примере программы капитального ремонта многоквартирных домов ЯНАО.

России в качестве одного из наиболее важнейших направлений социальноэкономического преобразования выступает развитие жилищной среды, которая создает все необходимые условия для человека. В качестве основы в данной сфере выступает жилищное строительство и жилищное хозяйство, обеспечивающее воспроизводство и содержание фонда, доведение жилищно-коммунальных услуг до потребителя.

В нашей стране жилищно-коммунальное хозяйство является одной из наиболее актуальных социально-экономических проблем, поскольку задачи, которые должна выполнять данная сфера далеко не всегда выполняются, что в свою очередь влияет на качество жизни населения.

В государственной политике приоритетной задачей стоит повышение уровня благосостояния населения, одним из решений выступает обеспечение доступности жилья и жилищных услуг для каждого гражданина.

В качестве основных жилищных проблем выступает:

- Устаревание жилищного фонда;

- Износ основных коммуникаций;

- Низкий рост нового жилого строительства;

- Дефицит инвестиционных ресурсов, следовательно, низкий уровень инвестиционной активности.

Согласно статистике, количество введенных в действие жилых домов в расчете на 1000 чел. в РФ на 2018 г составляет 500 кв.м., по сравнению с 2017 г, данный показатель упал (рис. 1) [7].

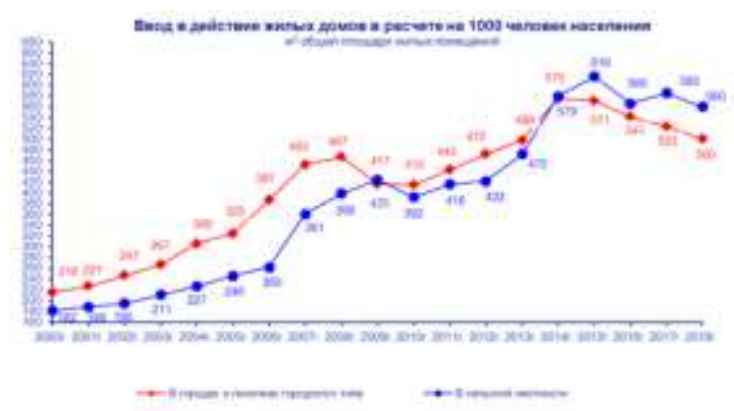

Рис. 1 Ввод в действие жильх домов в расчете на 1000 человек населения 
Данные показатели часто варьируются, т.к. большое количество жилищного фонда является необследованным и многие жилые дома, находящиеся в непригодном для жилья состоянии, до сих пор не входят в проекты по благоустройству и реконструкции. При этом учет технического состояния жилищного фонда не ведется. В результате этого определить сроки проведения, сметную стоимость ремонтно-строительных работ капитального и текущего ремонта такого фонда в целом не представляется возможности.

В Ямало-ненецком автономном округе проведением капитального ремонта регулируется Фондом капитального ремонта многоквартирных домов в ЯНАО Региональный оператор, который существует с 2016 года. Основной целью деятельности является обеспечение своевременного проведения капитального ремонта общего имущества в многоквартирных домах, расположенных на территории Ямало-Ненецкого автономного округа [4].

Основными функциями данного фонда выступают:

- Финансирование расходов на капитальный ремонт общего имущества в многоквартирных домах, собственники помещений в которых формируют фонды капитального ремонта на счете, счетах Регионального оператора, в пределах средств этих фондов капитального ремонта с привлечением при необходимости средств, полученных из иных источников, в т.ч. из бюджета Ямало-Ненецкого автономного округа и (или) бюджетов муниципальных образований Ямало-Ненецкого автономного округа.

- Формирование и актуализация региональной программы капитального ремонта общего имущества многоквартирных домов, расположенных на территории Ямало-Ненецкого автономного округа.

Согласно главе 17 Жилищного кодекса Российской Федерации, в качестве главного источника финансирования капитального ремонта выступают средства, сформированные на специальных счетах и счете Регионального оператора, средства бюджетов муниципальных образований и областного бюджета [1].

Согласно Постановление Правительства Ямало-Ненецкого автономного округа от 14 марта 2018 г. N 264-П «О внесении изменения в размер предельной стоимости услуг и (или) работ по капитальному ремонту общего имущества в многоквартирном доме, которая может оплачиваться региональным оператором за счет средств фонда капитального ремонта, сформированного исходя из минимального размера взноса на капитальный ремонт, на 2017 - 2019 годы», стоимость работ по капитальному ремонту общего имущества в многоквартирных домах, расположенных на территории ЯмалоНенецкого автономного округа, используемая для расчета софинансирования капитального ремонта за счет государственной поддержки капитального ремонта, выделяемой из бюджета Ямало-Ненецкого автономного округа, не должна превышать предельной стоимости проведения капитального ремонта [2].

Таблий 1

Размер предельной стоимости услуг и (или) работ по капитальному ремонту общего

имущества в многоквартирном доме, которая может оплачиваться региональным оператором за счёт средств фонда капитального ремонта, сформированного исходя из минимального размера взноса на капитальныий ремонт, на 2019 год [2]

\begin{tabular}{|c|c|c|c|}
\hline & & $\begin{array}{c}\text { Размер предельной стоимости в расчете на } \\
\text { один квадратный метр общей площади } \\
\text { помещений в многоквартирных домах, за } \\
\text { п/п }\end{array}$ & $\begin{array}{c}\text { Мсключением мест общего пользования } \\
\text { (тыс. руб.) }\end{array}$ \\
\cline { 2 - 4 } & & $\begin{array}{c}\text { дома капитального } \\
\text { исполнения }\end{array}$ & $\begin{array}{c}\text { дома деревянного } \\
\text { исполнения }\end{array}$ \\
\hline 1 & 2 & 3 & 4 \\
\hline 1 & Город Салехард & 10,50 & 14,50 \\
\hline 2 & Город Лабытнанги & 10,50 & 14,50 \\
\hline 3 & Надымский район & & \\
\hline
\end{tabular}




\begin{tabular}{|c|c|c|c|}
\hline 3.1 & Город Надым & 10,50 & 14,50 \\
\hline 3.2 & Иные поселения в составе района & 11,80 & 16,50 \\
\hline 4 & Город Новый Уренгой & 10,50 & 14,50 \\
\hline 5 & Город Ноябрьск & 10,50 & 14,50 \\
\hline 6 & Город Муравленко & 10,50 & 14,50 \\
\hline 7 & Город Губкинский & 10,50 & 16,50 \\
\hline 8 & Шурышкарский район & 11,85 & 16,20 \\
\hline 9 & Приуральский район & 11,60 & 18,20 \\
\hline 10 & Ямальский район & 13,00 & 17,40 \\
\hline 11 & Тазовский район & 12,50 & 17,00 \\
\hline 12 & Пуровский район & 12,20 & 18,60 \\
\hline 13 & Красноселькупский район & 13,30 & \\
\hline
\end{tabular}

Следует отметить, что собственники жилья перед принятием решения о финансировании какого-либо вида работ по капитальному ремонту должны удостовериться в возможности его оплаты за счет средств фонда капитального ремонта, сформированного с учетом минимального размера взноса на капитальный ремонт.

Согласно последним тенденциям современного города и особенностей капитального ремонта, можно сделать вывод о том, что увеличение качества жилого фонда актуальна и в России, и за рубежом. Проведя анализ возможных решений данной проблемы, на мой взгляд методика В.В. Киевлева показалась наиболее актуальной и осуществимой. Он предлагает на региональном уровне создание Резервного фонда капитального ремонта, где главным источником финансирования будет выступать налог на имущество, т.к. налоговой базой для значительной части взимаемого налога являются многоквартирные дома. Для этого предлагается ежегодно на федеральном уровне утверждать размер ставки отчислений в Резервный фонд. На данный момент целесообразно установить его в размере $30 \%$ от общей суммы налога на имущество, собираемого в конкретном регионе. В таком случае появится возможность повысить долю расходов на жилищный фонд по отношению к ВВП. В таблице 2 представлен расчет средств Фонда по ЯНАО.

Таблий 2

Расчет формирования средств Резервного фонда капитального ремонта ЯНАО (рассчитано по данным [3])

\begin{tabular}{|c|c|}
\hline Налог & Сумма, руб \\
\hline $\begin{array}{c}\text { Налог на имущество физических лиц, взимаемый по ставкам, применяемым к } \\
\text { объектам налогообложения, расположенным в границах городских округов }\end{array}$ & 14278176,21 \\
\hline $\begin{array}{c}\text { Налог на имущество физических лиц, взимаемый по ставкам, применяемым к } \\
\text { объектам налогообложения, расположенным в границах сельских поселений }\end{array}$ & 1163402,63 \\
\hline $\begin{array}{c}\text { Налог на имущество физических лиц, взимаемый по ставкам, применяемым к } \\
\text { объектам налогообложения, расположенным в границах городских поселений }\end{array}$ & 3763912,49 \\
\hline Итого & 19205491,33 \\
\hline Ставка отчислений в резервный фонд & $30 \%$ \\
\hline Средства Фонда & 5761647,40 \\
\hline
\end{tabular}

Проведя анализ представленных выше данных, можно сказать о том, что на капитальный ремонт ЖФ ЯНАО можно дополнительно получить 5 761 647,40 руб. Если взять во внимание тот факт, что ежегодно на протяжении пяти лет сумма налога будет увеличиваться, то будут расти и средства Фонда, далее накапливаться финансовые ресурсы и, соответственно, больше квадратных метров жилья будет отремонтировано.

При существующем расчете на капитальный ремонт в 2019 г. рассчитывается исходя из тарифа в 10.5 руб. за квадратный метр жилья [3]. По мнению автора, необходимо увеличить его с учетом индекса потребительских цен на 30,79\%. Расчет представлен в таблице 3. 
Таблицуа 3

Индексы потребительских ичен на товары и услуги, проиент, Ямало-Ненеикий автономный округ, Базовый индекс потребительских иеен, в \% к предыдущцему месяиу [5]

\begin{tabular}{|c|c|c|c|c|c|c|}
\hline & 2014 & 2015 & 2016 & 2017 & 2018 & 2019 \\
\hline январь & 106,88 & 110,32 & 108,63 & 104,76 & 101,24 & 102,13 \\
\hline февраль & 106,7 & 110,48 & 108,23 & 104,46 & 102,47 & 101,07 \\
\hline март & 106,88 & 111,5 & 108,29 & 102,98 & 102,48 & 101,13 \\
\hline апрель & 106,37 & 111,92 & 107,75 & 102,77 & 102,41 & 101,12 \\
\hline май & 107,54 & 110,87 & 107,65 & 102,58 & 102,22 & 100,49 \\
\hline июнь & 107,83 & 110,45 & 107,55 & 102,43 & 102,25 & 100,34 \\
\hline июль & 107,87 & 110,01 & 107,91 & 102,1 & 102,49 & 100,47 \\
\hline август & 108,41 & 110,03 & 107,28 & 101,94 & 102,63 & 100,16 \\
\hline сентябрь & 108,17 & 111,18 & 105,86 & 101,82 & 102,77 & 99,91 \\
\hline октябрь & 108,24 & 111,31 & 105,59 & 101,51 & 102,82 & 99,70 \\
\hline ноябрь & 108,45 & 111,02 & 105,09 & 101,51 & 102,32 & 99,14 \\
\hline декабрь & 108,06 & 111,32 & 104,63 & 101,21 & 102,26 & 98,98 \\
\hline $\begin{array}{c}\text { Среднее } \\
\text { значение }\end{array}$ & 107,62 & 110,87 & 107,04 & 102,51 & 102,36 & $100,39 *$ \\
\hline
\end{tabular}

*Даннье за 2019 год (апрель-декабрь) спрогнозировань

Таблица 4

Расчет прочента повышения тарифа на капитальный ремонт к уровню цен предыдущего года, \%

\begin{tabular}{|c|c|c|c|c|c|c|c|}
\hline Года & 2014 & 2015 & 2016 & 2017 & 2018 & 2019 & Итого \\
\hline $\begin{array}{c}\text { Индекс } \\
\text { потребительских } \\
\text { цен }\end{array}$ & 107,62 & 110,87 & 107,04 & 102,51 & 102,36 & 100,39 & 30,79 \\
\hline
\end{tabular}

Расчет процента повышения индекса потребительских цен:

$$
\frac{\text { Текущий тариф за кв.м.жилья }}{100 x \text { Процент повышения тарифа }}=\frac{10,5}{100 \times 30,79}=3,23 \%
$$

Расчет нового тарифа взноса на капитальный ремонт:

Процент повышения ИПЦ + Текущий тари $\phi=3,23+10,5=13,37 \frac{\text { руб }}{\text { кв. м. }}$

Для расчета финансирования капитального ремонта необходим объем жилого фонда, представленный в таблице

Таблий 5

Сводная статистика по годам постройки, площади и количеству зарегистрированных жителей в жилом фонде* [6]

\begin{tabular}{|c|c|c|c|c|}
\hline № & Года & Кол-во домов & Площадь м2 & $\begin{array}{c}\text { Кол-во } \\
\text { зарегистрированных }\end{array}$ \\
\hline 1 & $1970-1979$ & 44 & 5898.80 & 133 \\
\hline 2 & $1980-1989$ & 645 & 994962.74 & 47864 \\
\hline 3 & $1990-1999$ & 166 & 519704.95 & 23857 \\
\hline 4 & $2000-2009$ & 27 & 110947.50 & 4592 \\
\hline
\end{tabular}

*Возьмем данные за с 2010-2019 год - 116 719,2 кв.м.

Расчет финансирования капитального ремонта, исходя из повышенного тарифа, представлен в таблице 6.

Таблицุа 6

Расчет финансирования капитального ремонта

\begin{tabular}{|c|c|c|c|c|}
\hline $\begin{array}{c}\text { Объем } \\
\begin{array}{c}\text { фонда, } \\
\text { тыс,кв.м. }\end{array}\end{array}$ & $\begin{array}{c}\text { Новый тариф } \\
\text { взноса на } \\
\text { капитальный } \\
\text { ремонт, руб. }\end{array}$ & $\begin{array}{c}\text { Старый тариф взноса } \\
\text { на капитальный } \\
\text { ремонт, руб. }\end{array}$ & $\begin{array}{c}\text { Разница, } \\
\text { тыс.руб. }\end{array}$ & $\begin{array}{c}\text { Итого за месяц, } \\
\text { тыс.руб. }\end{array}$ \\
\hline 116719,2 & 13,73 & 10,50 & 377003,02 & 1602554,62 \\
\hline
\end{tabular}


Всего по области - 116 719,2 кв.м. жилого фонда, следовательно, за месяц будет собираться 1602 554,62 тыс.руб.

$116719,2 \times 13,79 \times 12=19314639,22$

Таким образом, будут получены дополнительные средства, источники финансирования представлены на рисунке 2.

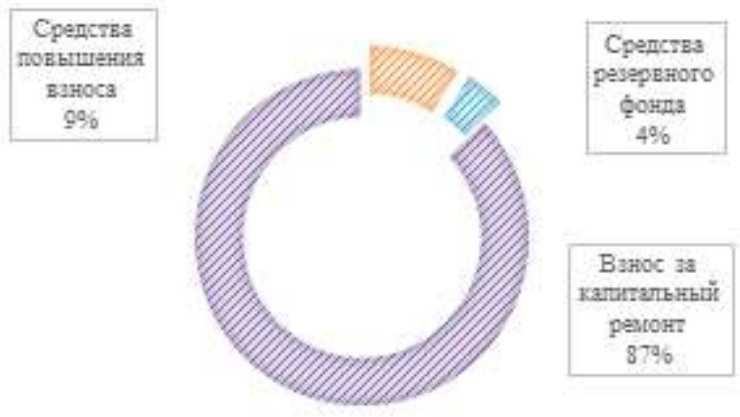

Рис. 2 Источники финансирования

Если ввести предлагаемый нами механизм финансирования, то это позволит ежегодно значительно увеличить объемы жилищного фонда и уменьшать объемы жилых помещений, которые подлежат капитальному ремонту.

Исходя из вышеизложенного, можно сделать вывод о том, что сегодня в ЯмалоНенецком автономном округе и в России ситуация в сфере организации капитального ремонта складывается крайне негативными моментами: отсутствие законодательной регламентации механизмов финансирования реновационных мероприятий, отсутствие мотивации собственников жилья на проведение капитального ремонта, дефицит источников финансирования.

В статье предложены мероприятия по созданию Резервного фонда и повышению износа на капитальный ремонт, что позволит, в свою очередь, увеличить объемы реконструируемых ежегодно домов. Введенный метод позволит провести комплексный капитальный ремонт общего имущества многоквартирных домов и обеспечит возможность для собственников проживать в жилых домах, удовлетворяющих всем социальным нормам по комфорту, безопасности и благоустройству.

$$
* * *
$$

1. Жилищный кодекс Российской Федерации" от 29.12.2004 N 188-Ф3 (ред. от 15.04.2019) (с изм. и доп., вступ. в силу с 26.04.2019) // Консультант плюс [официальный сайт]. Условия доступа: http://www.consultant.ru/document/cons_doc_LAW_51057/

2. Постановление Правительства Ямало-Ненецкого автономного округа от 14 марта 2018 г. N 264-П «О внесении изменения в размер пре-дельной стоимости услуг и (или) работ по капитальному ремонту общего имущества в многоквартирном доме, которая может оплачиваться регио-нальным оператором за счет средств фонда капитального ремонта, сформированного исходя из минимального размера взноса на капитальный ремонт, на 2017 - 2019 годы» // Фонд капитального ремонта многоквартирных домов Ямало-Ненецкого автономного округа [официальный сайт]. Условия доступа: http://fondkr89.ru/?page_id=531

3. Консолидированный отчёт о кассовых поступлениях и выбытиях (ф.0503152) на 01.10.2018 // УФК по Ямало-ненецкому автономному округу [официальный сайт]. Условия доступа: http://yamalonenetskiy.roskazna.ru/novosti-i-soobshheniya/novosti/1334209/

4. Постановление правительства ЯНАО от 13.12.18 г №1273-П. Условия доступа: http://docs.cntd.ru/document/550285023

5. Территориальный орган Федеральной службы государственной статистики по ЯНАО. Индексы потребительских цен и цен производителей (в процентах). Условия доступа: http://www.gks.ru/dbscripts/cbsd/dbinet.cgi?pl\%3D1902001

6. Жилой фонд и многоквартирные дома Ямало-Ненецкого АО // ГОС ЖКХ [официальный сайт]. Условия доступа: http://gosjkh.ru/houses/yanao

7. Жилой фонд в населенном пункте Ноябрьск // ДОМ.МИНЖКХ [официальный сайт]. Условия доступа: http://dom.mingkh.ru/tyumenskaya-oblast/noyabrsk 
Возиянова Н.Ю.,Доронина И.Е.

Маркетинговая среда учреждения среднего профессионального образования и ее внешняя информационная составляющая

ГО ВПО «Донеикий нацииональный университет экономики и торговли имени Михаила Туган-Барановского»

(ДНР, Донеик)

doi: 10.18411/scienceconf-05-2019-45

idsp: scienceconf-05-2019-45

\section{Аннотация}

Предложен ряд классификаций сообщений, которые составляют внешнюю информационную среду учреждения среднего профессионального образования. Рассмотрены их основные характеристики, выделены свойства и особенности, влияющие на качество принимаемых решений. Перечислены виды маркетинговой деятельности по созданию информационно-аналитических продуктов, применяемые в продвижении образовательных услуг.

Ключевые слова: маркетинговая деятельность; маркетинговая среда; внешняя информационная среда; среднее профессиональное образование; информационноаналитические ресурсы.

\section{Absrtact}

A number of classifications of messages that make up the external information environment of secondary vocational education institutions are proposed. Their main characteristics are considered, the properties and features influencing quality of the made decisions are allocated. The types of marketing activities for the creation of information and analytical products used in the promotion of educational services are listed.

Постановка проблемы. Ни один социальный институт не может существовать без обмена информацией с внешним миром. Необходимо охарактеризовать внешний компонент информационной части маркетинговой среды современного института среднего профессионального образования (СПО) в разрезе взаимодействия субъектов маркетинговой деятельности на рынке образовательных услуг: учреждение (колледж), как поставщик образовательных услуг - абитуриент, как потребитель таких услуг.

Анализ последних исследований и публикаций показал, что Шаршов И.А. и Макарова Л.Н. в рамках реализации госзадания Министерства образования и науки РФ вузам в 2012 г., проекты №№ 6.2082.2012, 6.4640.2011 и 6.4600 рассмотрели понятие внешней информационной среды и проанализировали ее основные характеристики [3]. Копытова Н.Е. в рамках ФЦП «Научные и научно-педагогические кадры инновационной России на 2009-2013 гг.», проект № 2010-1.2.1-102-116-141 показала влияние изменяющейся информационной среды на систему образования [2]. В своих исследованиях авторы опираются на идеи, высказанные Шрейдером Ю.А. [4,5] и развитые Еляковым А.Д. [1].

Цель статьи - сгруппировать и систематизировать характеристики внешней информационной среды института среднего профессионального образования как субъекта рынка образовательных услуг.

Изложение основного материала. Внешняя информационная среда - это информация, которая поступает в учреждение среднего профессионального образования (колледж) из внешней среды и уходит из учреждения во внешнюю среду. Рассмотрим то множество сообщений, которые составляют внешнюю информационную среду учреждения среднего профессионального образования, выделим их свойства и особенности, влияющие на качество принимаемых решений. Их можно классифицировать (рис. 1): 
1) по направленности;

2) по характеру воздействия на адресат;

3) по содержанию;

4) по источникам.

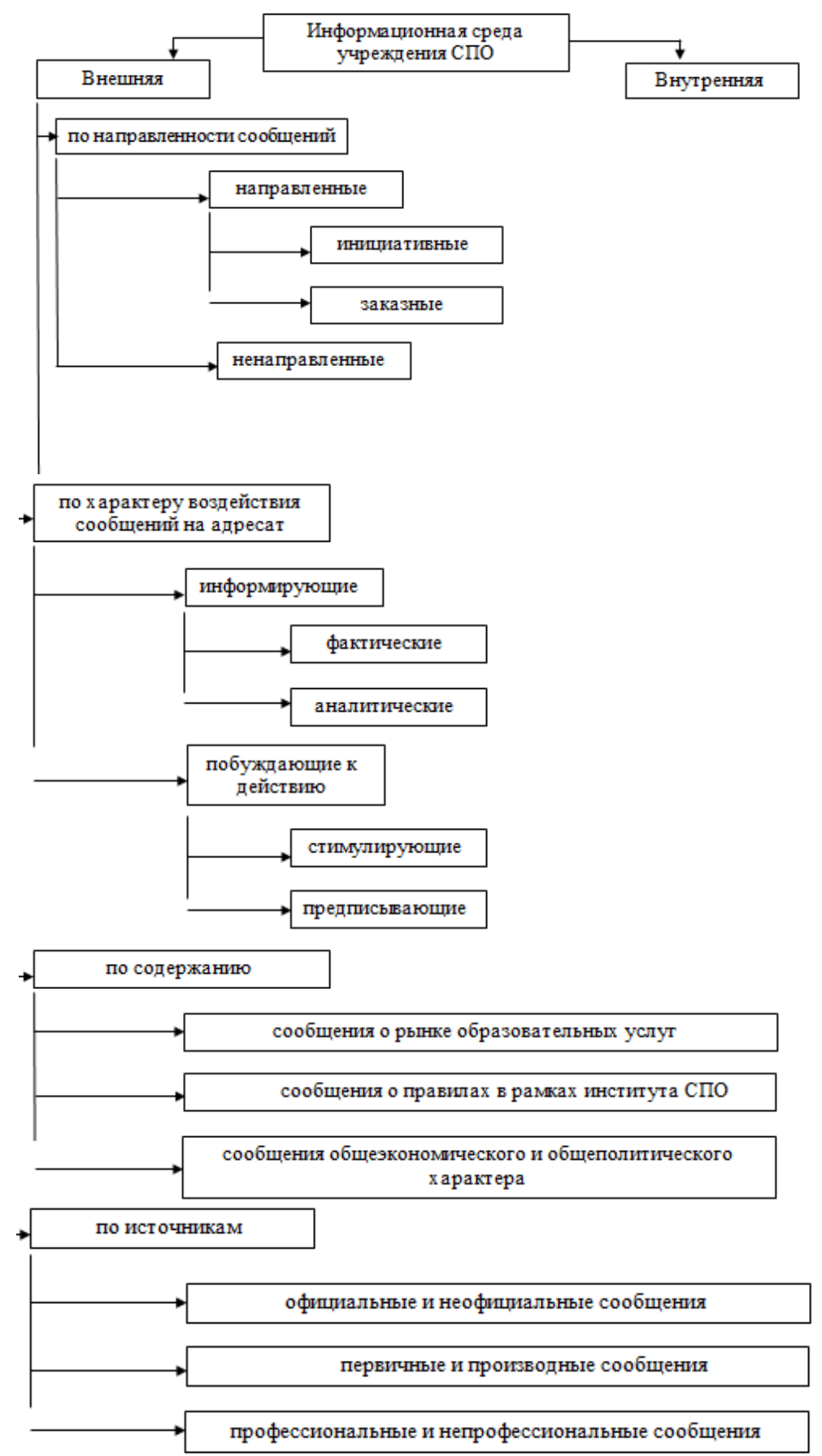

Рисунок 1. Информационная среда учреждения СПО и ее классификаџия

Следует заметить, что не все перечисленные классификации участвуют во взаимодействии учреждения среднего профессионального образования и потенциального абитуриента.

Целесообразно все сообщения, исходящие от учреждения СПО, разделить на направленные и ненаправленные.

Направленные сообщения генерируются и транслируются их авторами (источниками) непосредственно в адрес данного учреждения или наоборот, учреждение формирует и адресует некое сообщение конкретному пользователю - абитуриенту, учредителю, другому учреждению, организации или органу власти. Это могут быть 
письма, телефонные звонки, личные контакты. Направленные сообщения преследуют определенные цели отправителя - стремление к получению выгоды с помощью или за счет адресата. Следовательно, значимыми характеристиками направленных сообщений являются:

1) их истинность или ложность;

2) степень доверия адресата к источнику сообщения.

От этих характеристик направленных сообщений зависят такие трансакционные издержки адресата, как издержки поиска, приобретения и анализа информации и временные издержки. Предположим, что все направленные сообщения являются истинными, тогда затраты на их получение являются минимальными и сводятся к издержкам на поддержание в рабочем состоянии средств связи. Если полученное сообщение расценивается как возможно ложное, то затраты возрастают на величину издержек на проверку истинности сообщения. Вместе с тем обе характеристики находятся в обратно-пропорциональной зависимости друг от друга - издержки на проверку истинности сообщения тем ниже, чем выше уровень доверия к источнику данного сообщения. Следовательно, распределение внешних информационных потоков по уровню доверия к источникам поступающих направленных сообщений является одним из методов поиска оптимального решения, принимаемого потенциальным абитуриентом, с одной стороны, и снижения издержек управления колледжем с другой стороны.

В свою очередь направленные сообщения можно разделить на инициативные и заказные. Например, потенциальные абитуриенты и их родители инициативные сообщения получают пассивно, по воле и желанию колледжа. В то же время заказные направленные сообщения, инициируются их адресатом. Например, абитуриент обращается в колледж лично или с помощью телефона, электронной почты, формы обратной связи на официальном сайте и пр. с целью получения интересующих сведений о тех или иных процессах и событиях, которые представляются адресату важными для принятия решения.

Ненаправленные сообщения генерируются источником для целевой аудитории, а в идеале для всех, кто вероятно сможет получить данные сообщения. Например, реклама и публикации в средствах массовой информации размещаются учреждением среднего профессионального образования в расчете на отклик потенциального абитуриента. Также примером может служить публикация принятых локальных нормативно-правовых актов и размещение информации на официальном сайте конкретного учреждения.

Основной характеристикой ненаправленных сообщений является необходимость и для автора, и для адресата (в зависимости от поставленных целей) предпринять определенные действия, что влечет трансакционные издержки поискового и временного характера. Потенциальный абитуриент тратит время на обработку и классификацию по степени доверия ненаправленных сообщений, а колледж несет затраты по созданию и распространению информационного продукта.

Принято считать, что уровень доверия к ненаправленным сообщениям выше, чем к направленным по причине отсутствия прямой заинтересованности отправителя в выгоде от конкретного адресата. Но мы придерживаемся противоположной точки зрения. Учреждение формирует направленные сообщения с большей ответственностью, таким образом, в перспективе создавая перевес доверия именно к таким сообщениям.

Также сообщения можно разделить по характеру воздействия на адресат, ожидаемому инициатором сообщения: информирующие и побуждающие к действию. Следовательно, такая классификация связана в большей степени с намерениями автора (источника) сообщения. Независимо от разделения сообщений в данной классификации, их необходимо также охарактеризовать с точки зрения их истинности или ложности, с одной стороны, и уровня доверия к источнику сообщения, с другой.

Сообщения, побуждающие к действию, в свою очередь, предлагаем разделить на стимулирующие и предписывающие. Стимулирующие сообщения содержат сведения, 
открывающие для адресата новые возможности, или, более точно, сведения, говорящие о том, как и где можно получить такие возможности. Примером стимулирующего сообщения является рекламный текст или предложение о посещении мероприятий учреждения. При этом именно адресат - потребитель анализирует выгоды и издержки от реализации данного предложения и принимает решение о том, осуществить или не осуществить предлагаемые возможности.

Предписывающие сообщения в определенной мере ограничивают свободу выбора адресата, оставляя ему готовый набор вариантов. Примером могут служить Правила приема в колледж и т.п. Однако и здесь на практике у абитуриента есть возможность выбора - следовать данному предписанию либо нет. При таком выборе, как и в первом случае, происходит сравнение выгод и издержек от реализации соответствующего варианта.

Вернемся к информирующим сообщениям. Они не побуждают получателя непосредственно к каким-либо шагам, хотя в дальнейшем сказываются на принятии решений. Например, это могут быть сообщения об изменениях цен, предоставлении дополнительных услуг по профессиональному обучению, объявление об аккредитации направления и т.п.

Основной характеристикой информирующих сообщений является их фактичность или аналитичность. Фактические информирующие сообщения истинно или ложно сообщают об определенных событиях и процессах. Извлечение из этих данных существенной для абитуриента информации требует от него временных затрат. Аналитические сообщения уже содержат выводы из анализа, обобщения и сопоставления иных фактических сообщений. На их формирование источник также потратил время, но они являются и более ценными, чем фактические. Очевидно, что потребитель будет принимать решение, исходя из уровня доверия к автору сообщения, рассчитывая, что поставщик образовательных услуг вел исследования в соответствии с устремлениями потребителя. Таким образом, мы исключаем целенаправленную дезинформацию адресата, как имеющую высокие трансакционные издержки.

Классификация сообщений по содержанию возможна в группах:

- сообщения о рынке образовательных услуг;

- сообщения о правилах в рамках института среднего профессионального образования;

— сообщения общеэкономического и общеполитического характера.

Информация о рынке образовательных услуг характеризует непосредственно сами представленные услуги, цены, особенности получения и пр. Эти данные могут быть как актуальными, отражая текущую ситуацию, так и относиться к прошлым и будущим периодам времени. Также, они могут быть фактическими или аналитическими.

Сообщения о правилах в рамках института среднего профессионального образования включают две подгруппы:

1) официальные документы - законы, постановления, приказы, инструкции, принятые органами государственной власти, а также распорядительные и локальные нормативно-правовые акты учреждения или учредителя;

2) информация о неформальных правилах. Такая информация чаще всего имеет устный, направленный и конфиденциальный характер.

Информация общеэкономического и общеполитического характера также может быть как направленной, так и ненаправленной, официальной и неофициальной.

Последней рассматриваемой классификацией является распределение по характеру источника сообщений. Кратко опишем полученные группы сообщений в Таблице 1. 
Группы сообщений по источникам и их характеристика

\begin{tabular}{|l|l|}
\hline Группы сообщений & Характеристика \\
\hline $\begin{array}{l}\text { Официальные и неофициальные } \\
\text { сообщения }\end{array}$ & $\begin{array}{l}\text { Официальность сообщения будем трактовать как готовность } \\
\text { источника подтвердить достоверность сведений. Однако это не } \\
\text { означает истинность сообщения. }\end{array}$ \\
\hline $\begin{array}{l}\text { Первичные и производные } \\
\text { сообщения }\end{array}$ & $\begin{array}{l}\text { Первичные исходят непосредственно от тех организаций, } \\
\text { сведения о которых в них содержатся. Производные } \\
\text { представляют собой авторскую интерпретацию данных. }\end{array}$ \\
\hline $\begin{array}{l}\text { Профессиональные и } \\
\text { непрофессиональные сообщения }\end{array}$ & $\begin{array}{l}\text { Профессиональные исходят от организаций и лиц, } \\
\text { специализирующихся на производстве соответствующих } \\
\text { знаний. Непрофессиональные содержат суждения и оценки } \\
\text { неспециалистов. }\end{array}$ \\
\hline
\end{tabular}

Данная классификация важна для оценки точности и достоверности содержания сообщения.

Приведенные классификации сообщений, составляющих внешнюю информационную среду института среднего профессионального образования, являются относительно независимыми друг от друга. Следовательно, на основе их пересечения возможно дальнейшее построение других типологий. Например, пересечение группы аналитических сообщений с группой сообщений о рынке образовательных услуг позволяет получить классификацию таких видов деятельности:

— обзор динамики цен;

- рекламная деятельность, заключающаяся в ознакомлении потенциальных потребителей с достоинствами поставщика, в выработке у потребителей устойчивого положительного образа (имиджа) услуги или учреждения;

- консалтинговая деятельность;

- рейтинговая деятельность.

Выводы. Как показали проведенные нами исследования, в информационном поле наиболее действенным видом маркетинговой деятельности, применяемым в продвижении образовательных услуг, является создание таких информационно-аналитических продуктов, как интернет-сайты, группы в социальных сетях, справочно-информационные, аналитические и рейтинговые системы. Официальный сайт учреждения среднего профессионального образования охватывает наибольшую часть классифицируемой информации. Он генерирует ненаправленные, официальные, первичные, профессиональные сообщения всеобъемлющие по содержанию, как информирующие, так и побуждающие к действию, а также откликается на заказные направленные сообщения. Работа в социальных сетях предполагает акцент на направленные сообщения. Справочноинформационные и рейтинговые системы направлены на прямые предложения образовательных услуг. В дальнейшем предполагаем сосредоточиться на поиске решений по лучшему применению различных характеристик сообщений с целью увеличения объема реализации образовательных услуг.

$$
\text { *** }
$$

1. Еляков А.Д. Современная среда человечества в информационно-компьютерном измерении (опыт аналитической оценки) // НТИ. Сер. 1. 2009. № 5.

2. Копытова Н.Е. Высшее образование в изменяющейся информационной среде // Вестник Тамбовского университета. Серия Гуманитарные науки. Тамбов, 2011. Вып. 11 (130). С.130-136.

3. Шаршов И.А., Макарова Л.Н. Изменяющаяся внешняя информационная среда: анализ конструктивного и деструктивного потенциала/ И.А. Шаршов, Л.Н. Макарова// Социальноэкономические явления и процессы. - 2012. - № 4 (038). - С.170-176.

4. Шрейдер Ю.А. Проблемы развития инфосреды и интеллект специалиста // Интеллектуальная культура специалиста. Новосибирск, 1988. С. 110-136.

5. Шрейдер Ю.А. Информационные процессы и информационная среда // Научно-техническая информация. Сер. 2. 1976. № 1. 


\title{
Горский М.А. \\ Параметрическая модель и результаты ее адаптации в деятельности российского коммерческого банка
}

ГК Рест-Групn

(Россия, Москва)

doi: 10.18411/scienceconf-05-2019-46

idsp: scienceconf-05-2019-46

\begin{abstract}
Аннотация
В статье предложена концепция и оригинальная экономико-математическая модель параметрической оптимизации кредитно-инвестиционной деятельности коммерческого банка. В качестве параметров рассматриваются экзогенные и эндогенные факторы, определяющие макроэкономические условия и политику банка в сфере привлечения инвестиционных ресурсов и ограничения кредитно-инвестиционной деятельности с учетом требований регулятора - ЦБ по величине резервов, уровню ликвидности и кредитному риску портфеля. Использование параметрического подхода позволяет оперативно провести анализ влияния на структуру банковского портфеля, соотношение «доходность-риск» и другие показатели кредитно-инвестиционной деятельности изменения этих и других параметров.

В качестве важного приложения параметрической модели оптимизации банковского портфеля предложены оригинальный подход к обоснованию феномена финансовой устойчивости банка в условиях изменчивости экзогенных параметров его деятельности и метод оценки интервала устойчивости структуры оптимального портфеля.

Ключевые слова: коммерческий банк, портфель депозитов-ссуд, кредитноинвестиционная деятельность, математическое моделирование, модели банковской деятельности, кредитная стратегия банка.
\end{abstract}

Эффективное функционирование банковской системы России-основа роста ее экономики и социальной сферы. По этой причине рост эффективности банковского сектора является приоритетной задачей поступательного развития национальной экономики.

Банковский менеджер, принимающий решения по управлению банковским портфелем в условиях неполной и неточной информации о движениях финансовых рынков, вынужден учитывать сопутствующие риски, связанные с возможным снижением доходности и качества активов, и выстраивать кредитно-инвестиционную политику банка, исходя из приоритетов его рыночной стратегии, в ряду которых на современном этапе значимы сохранение устойчивости, рост надежности финансово-экономической основы и конкурентоспособности банка в основных направлениях деятельности $[9,11,23,33,34]$.

В свою очередь, эта проблема, формулируемая как задача выбора наилучшего из имеющихся альтернатив решения при управлении деятельностью сложных социальноэкономических систем, к которым относятся и коммерческие банки, в условиях неполноты информации и связанного с ней риска, - предмет изучения целого комплекса научных дисциплин, в том числе, экономических и математических, использующих методы системного анализа, исследования операций, оптимального управления и математического моделирования.

Методологические основы работы.

К настоящему времени математическая теория банков и банковской деятельности приобрела вполне законченный вид, а инструментарий моделей и методов управления банковским портфелем весьма разнообразен. В работе Дж. Синки [24] приведён подробный анализ развития математической теории банковской деятельности во второй половине 20-го века. Перечень цитируемых автором литературных источников включает 
значительное (более 60-ти) работ, в которых используются различные экономикоматематические модели банковского портфеля: оптимизационные, стохастические, балансовые, запасов, марковских процессов, теории игр и т.п.

Вопросы анализа эффективности и управления коммерческим банком в условиях изменчивых параметров товарных и финансовых рынков, в том числе, проблематика выбора критериев оптимальности и экономико-математического моделирования оптимального банковского портфеля достаточно полно отражены в трудах российских: Белоглазовой Г.Н. и Кроливецкой Л.П [4], Бородина А.В [6], Бурухановой Т.Д. [8], Егоровой Н.Е. и Смулова А. [11], Жуковой Е.Ф. и Эриашвили Н.Д. [12], Зайцевой М.В. [13], Киселевой И.А. [15], Когана В.И. [16], Криночкина Д.Л [17], Лаврушина О.И. [18], Панова Г.С. [21], Пуртикова В.А. [22], Уразаевой Т. [22], Халикова М.А. и Антиколь А.М. [30] и авторитетных западных: Бренда Р. [7], Роуза П. [23], Синки Дж. [24], Буша А. [31], Клини М. [32], Мэрфи Н. [34], Сили К. [35] ученых и специалистов-практиков.

Представленный в цитируемых выше работах инструментарий экономикоматематических моделей и методов оценки качества и оптимального управления кредитно-инвестиционным портфелем коммерческого банка можно условно разделить на группы «частных» и «полных» моделей «банковской фирмы».

Модели первой группы, в ряду которых особо отметим модели Зайцевой М. В. [13] и Уразаевой Т. А. [26], предназначены для решения отдельных задач планирования и управления банковскими портфелями ( в отмеченных работах-выбор процентных ставок по депозитам и кредитам, прогнозирование денежных потоков, моделирование кредитного, процентного рисков и др. параметров портфеля и отдельных его составляющих ).

Напротив, полные модели предназначены для выбора и обоснования комплексных стратегий банка в основных сферах банковской деятельности и оптимизации кредитноинвестиционного портфеля банка по расширенному набору критериев качества кредитного портфеля и эффективности кредитной деятельности. В перечне этих моделей выделим модели Буша А. [31], Мэрфи Н. [34], Сили К. [35] (в статичном варианте), Когана В.[16], Бурухановой Т. Д.[8], Горского М.А. и Халикова М. А.[9] (в динамическом варианте), ориентированные на выбор и оптимальное управление кредитным портфелем по критериям «доходность- риск» и учетом ограничений по нормативам ликвидности и риска.

Для условий макроэкономической нестабильности особое значение приобретают исследования, связанные с совершенствованием теоретических моделей и практических приемов кредитно-инвестиционной деятельности российских коммерческих банков в направлении уточнения критериев оптимальности, внешних и внутренних ограничений.

Например, рядом авторов $[9,22]$ в составе критериев оптимальности банковского портфеля наряду с доходностью и кредитным риском предложено учитывать ликвидность временной структуры совокупного портфеля активов-пассивов, что позволяет оптимизировать кредитную стратегию банка на очередном временном интервале с учетом коррекции объема и структуры кредитного портфеля по результатам мониторинга и оценки его качества на текущем временном интервале. В работе автора [9] показано, что учет ликвидности баланса активно-пассивных операций по объемам и срокам в критериях кредитной деятельности способствует решению ставшей «традиционной» для большинства российских коммерческих банков (включая и крупные) проблемы несоответствия «короткой» ресурсной базы (пассивов) и «длинных» рисковых активов основной причины снижения их ликвидности и финансовой устойчивости.

В цитируемой и других работах автора и его соавторов [3,30,33] отмечено, что деятельности в современных условиях повышение эффективности кредитноинвестиционной деятельности наиболее значимо для средних по объему собственного капитала универсальных коммерческих банков (занимающихся розничным, корпоративным кредитованием и проектным финансированием), для которых этот вид 
деятельность является основным источником доходов и которые находятся под внешним контролем регулятора и внутренним со стороны акционеров и вкладчиков.

\section{Основные результаты работы}

В продолжении исследований автора в направлении экономико-математического моделирования банковского портфеля в условиях неопределенности и риска в настоящей работе представлены результаты разработки и адаптации в практической деятельности исследуемого коммерческого банка моделей и методов оптимизации кредитноинвестиционного портфеля с расширенным набором критериев качества и учетом экзогенных и эндогенных параметров, определяющих альтернативные варианты банковской деятельности и приоритеты кредитно-инвестиционной стратегии коммерческого банка.

Необходимость разработки таких моделей нами связывается с решением актуальной для российской банковской системы, функционирующей в условиях отсутствия «дешевых» долгосрочных источников пополнения инвестиционного капитала, проблемы формирования оптимального банковского портфеля с учетом высокой изменчивости параметров внешней и внутренней сред.

Переходя к изложению результатов работы, отметим, что в основе большинства подходов к моделированию банковской деятельности лежит неоклассическая концепция коммерческого банка как агента рынка денег [4,7,12,18,23,31,32], оказывающего услуги посреднического типа по трансформации «свободных» денег держателей депозитов в ссудный капитал, предоставляемый заёмщикам на принципах срочности, возвратности и платности. Интерпретация банка как «банковской фирмы» позволяет успешно применять основные выводы неоклассической теории фирмы, включающие соотношения, связывающие эффективность деятельности на финансовом рынке с предельной отдачей собственного и заёмного капитала, соотношения ценообразования на депозиты и кредиты на уровне предельных затрат обслуживания соответствующих портфелей и др. результаты, относящиеся к моделированию динамики «выпуск - затраты» на основе двойственных оценок финансовых ресурсов, привлекаемых в пассивы банка [2].

Моделирование деятельности коммерческого банка на основе «производственного» подхода весьма перспективно в описаниях процедур принятия кредитного решения [6], выбора ставок по депозитам и кредитам [26], согласования объёмов активно-пассивных операций на основе балансовых моделей и прогнозирования финансовых потоков коммерческого банка [8,15,17,21,22]. Перечисленные оптимизационные и прогнозные модели с полным основанием относятся к отмеченным выше «частным» моделям «банковской фирмы», ориентированным на решение конкретных задач выбора и управления банковским портфелем.

Решение комплексной задачи оптимизации этого портфеля с учётом параметров внешних по отношению к банку финансовых рынков и рыночных регуляторов, внутренних нормативов и приоритетов кредитной политики банка в сфере ставок по кредитам и депозитам, как справедливо отмечал Н. Мэрфи [34], требует применения «полных» моделей, при построении которых ориентация только на неоклассическую концепцию банковской фирмы не позволяет адекватно отразить в критерии и ограничениях эти факторы, что и предполагает использование отличных от «производственной» концепций и моделей банковской деятельности.

Именно в рамках полных моделей «банковской» фирмы для задачи оптимизации банковской деятельности в условиях неполной и неточной информации о рынках депозитов и ссуд рассмотрим параметрическую модель выбора оптимального варианта кредитно-инвестиционной деятельности коммерческого банка.

Модель функционирования коммерческого банка (КБ) на внутреннем финансовом рынке страны в самом общем виде описывает процедуру формирования и трансформации денежных потоков инвестиций и прибыли от кредитно-инвестиционной, операционной и др. видов деятельности, осуществляемой банковской фирмой (Рис. 1). 
Приведем комментарии к эсементному составу отмеченных на Рис. 1 денежных потоков коммерческого банка:

$\mathrm{Rv}$ - поток средств сторонних инвесторов (государственные и корпоративные структуры, частные инвесторы, банки и инвестиционные компании);

Рp - возврат на привлекаемый на внешнем рынке инвестиционный капитал;

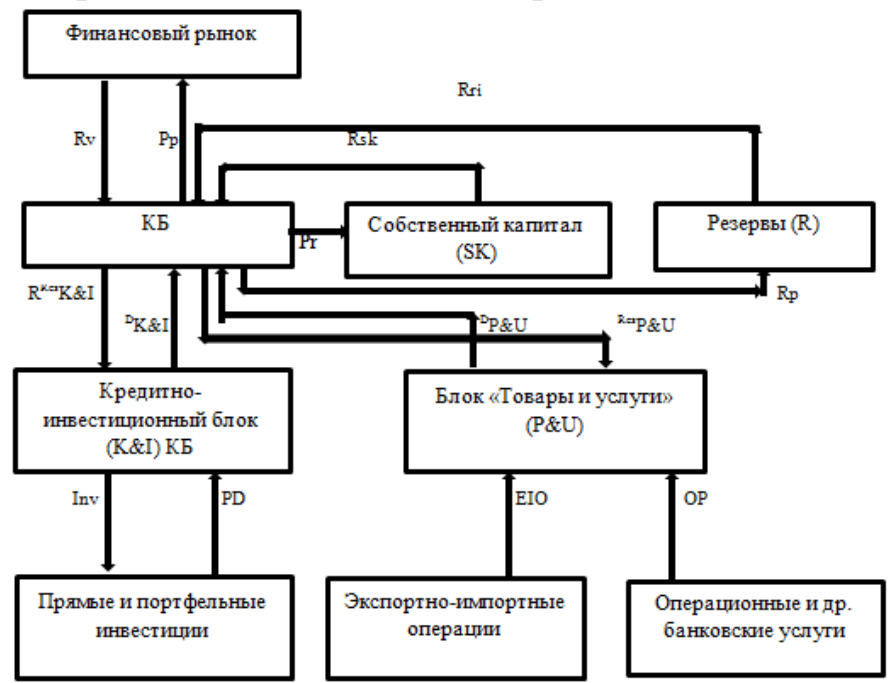

Рис. 1. Денежные потоки коммерческого банка, генерируемые в сферах кредитно-инвестиционной и операционной деятельности.

Rsk и $\operatorname{Pr}$ - потоки инвестиций соответственно из собственного капитала и резервов;

${ }^{R e s} \mathrm{~K} \& \mathrm{I},{ }^{\mathrm{Res}} \mathrm{P} \& \mathrm{U}, \mathrm{Rp}$ - денежные потоки, направляемые в инвестиции и затраты соответственно кредитно-инвестиционного блока, операционного блока и на пополнение банковских резервов;

${ }^{\mathrm{D}} \mathrm{K} \& \mathrm{I},{ }^{\mathrm{D}} \mathrm{K} \& \mathrm{U}$ - денежные потоки доходов, полученных соответственно в кредитноинвестиционном и оперативном блоках;

Inv - денежный поток инвестиций банка;

PD, EIO, OP - денежные потоки прибыли, полученной соответственно от: прямых и портфельных инвестиций, экспортно-импортных операций, операционных и др. банковских услуг;

$\operatorname{Pr}$ - денежный поток прибыли на увеличение собственного капитала.

Таким образом, источником инвестиций КБ, размещаемых кредитноинвестиционным блоком, является денежный поток, включающий средства, полученные на финансовом рынке, собственные средства и отчисления из резервов, не превышающие лимиты по ликвидности и риску. Объем этих источников, ограничивающий объем инвестиций банка, задается неравенствами:

$$
\begin{gathered}
\text { Inv } \leq{ }^{\text {Res }} \mathrm{K} \& \mathrm{I} ; \\
{ }^{\mathrm{Res}} \mathrm{K} \& \mathrm{I} \leq \mathrm{Rv}+\mathrm{Pr}+\mathrm{Rsk} ; \\
\mathrm{Rr} \leq(1-\alpha) \cdot \mathrm{R} \\
\mathrm{Rsk} \leq \beta \cdot \mathrm{SK},
\end{gathered}
$$

где: $\alpha$ - норматив обязательного резервирования, устанавливаемый с учетом требований регулятора (ЦБ) и кредитной политики КБ; $\beta$ - доля собственного капитала, направляемая в кредитно-инвестиционную деятельность (эндогенный (управляемый) параметр).

На величину денежного потока Rv внешних инвестиций решающее влияние оказывают емкость $\Omega$ финансового рынка страны, с учетом ставки рефинансирования $\gamma$ ограниченная величиной $\gamma \cdot \Omega$, и ставки по депозитам $T_{i}$, определяемые банком и дифференцированные по объемам с учетом срочности возврата:

$$
R v_{i}=R v_{i}\left(\gamma \Omega_{i}, \mathrm{~T}_{i}\right)
$$




$$
\mathrm{Rv}=\sum_{i=1}^{I} R v_{i}
$$

где: і - индекс группы инвесторов $(\mathrm{i}=\overline{1, I})$, обеспечивающих денежный поток инвестиций объемом $\Omega_{i} ; R v_{i}\left(\gamma \Omega_{i}, \mathrm{~T}_{i}\right)$ - нелинейная зависимость потока инвестиций от экзогенного параметра $\gamma$ и вектора эндогенных параметров с компонентами $\tau_{i}$ - ставок по депозитам.

С учетом ограничений кредитно-инвестиционной деятельности, задаваемых соотношениями (1) - (6), доступный КБ поток инвестиций определяется функционалом:

$$
\operatorname{Inv}=\operatorname{Inv}\left(\Omega_{i}^{T_{i}}(\mathrm{i}=1, \mathrm{I}) ; \mathrm{SK} ; \mathrm{R} ; \gamma, \alpha, \beta\right),
$$

где: $\gamma$ - экзогенный, а $\mathrm{T}_{i}, \alpha, \beta$ - эндогенные параметры, влияющие на величину потока.

Сформированный поток инвестиций распределяется по объектам кредитноинвестиционной деятельности КБ с учетом спроса на инвестиции и кредитных ставок:

$$
\begin{aligned}
& \max D_{K \& I} ; \\
& D_{K \& I}=\sum_{j=1}^{J} g_{j} x_{j} ; \\
& \sum_{j=1}^{J} x_{j} \leq \mathrm{Inv} ; \\
& 0 \leq x_{j} \leq X_{j}\left(k_{j}\right) ; \\
& g_{j}=g_{j}\left(k_{j}\right),
\end{aligned}
$$

где: $\mathrm{j}, k_{j}$ - соответственно номер и группа риска заемщика (кредитора, инвестиционного объекта); $g_{j}$ - кредитная ставка для заемщика (инвестиционного проекта) с номером $\mathrm{j}$; $X_{j}$ - максимальный объем кредита (инвестиций) для заемщика (инвестиционного проекта) с номером j.

Суммируя приведенное выше, можно констатировать, что параметрическая модель оптимального банковского портфеля может быть эффективно формализована на двух уровнях: на первом (соотношения (1) - (7)) определяется входной поток источников инвестиций, на втором (оптимизационная модель (8) - (12)) решается задача распределения сформированного потока по объектам приложения инвестиций с критерием на максимум процентного дохода кредитно-инвестиционной деятельности и ограничением на допустимую величину кредитного риска.

Численные алгоритмы решения задач первого и второго уровня включают и основываются на:

- методах и моделях аппроксимации нелинейных зависимостей $(5,11)$ спроса на депозиты, кредиты и инвестиции от объемов предложений и процентных ставок, представленных в работах [1,4,9,13,19,26,29,30];

- методах и моделях оценки свободных для размещения в инвестиции средств КБ, представленных в работе автора [9];

- моделях и методах нелинейной дискретной оптимизации, представленных в работе М.А. Халикова [29].

Модельные расчёты с использованием параметрической модели проводились автором для КБ XXX, являющегося средним по величине капитала универсальным банком. АКБ ХХX обладает значительной филиальной сетью. Каждый филиал имеет собственный корреспондентский счёт в ЦБ РФ.

Основные усилия банка направлены на проведение взвешенной политики в области управления рисками, развитие качественного комплексного банковского обслуживания клиентов и соблюдение их интересов, расширение спектра банковских услуг, повышение надежности и рыночной конкурентоспособности.

Оптимальный кредитный портфель банка XXX (таблица 1) рассчитывался для последовательных временных интервалов: 31.10, 30.11, 31.122017 г. Следует отметить, 
что портфель диверсифицирован, однако основная сумма приходится на кредиты, выданные негосударственным и коммерческим организациям (юридическим лицам) на сроки от 181 дня до 1 года и от 1 года до 3 лет.

Портфель депозитов банка (таблица 2) состоит из средств, полученных от физических лиц: резидентов и нерезидентов. Основную долю вкладчиков составляют физические лица- резиденты, а с позиции временной структуры преобладают депозиты сроком от 181 дня до 1 года и от 1 года до 3 лет.

Таблийа 1

Структура кредитного портфеля банка ХХХ (тыс. руб.)

\begin{tabular}{|c|c|c|c|c|c|c|c|c|c|c|}
\hline \multirow{2}{*}{ Счёт } & \multirow{2}{*}{ Группа счетов } & \multirow{2}{*}{ Название счета } & \multicolumn{4}{|c|}{ Основная сумма долга } & \multicolumn{4}{|c|}{$\begin{array}{l}\text { Просроченная } \\
\text { задолженность }\end{array}$} \\
\hline & & & 30.09 & 31.10 & 30.11 & 31.12 & 30.09 & 31.10 & 30.11 & 31.12 \\
\hline 45107 & \multirow[b]{2}{*}{$\begin{array}{c}\text { Кредиты, } \\
\text { предоставленные } \\
\text { негосударственным } \\
\text { финансовым } \\
\text { организациям }\end{array}$} & $\begin{array}{c}\text { на срок от } 1 \text { года до } 3 \\
\text { лет }\end{array}$ & $\begin{array}{c}21 \\
038\end{array}$ & $\begin{array}{c}19 \\
624\end{array}$ & $\begin{array}{c}18 \\
424\end{array}$ & $\begin{array}{c}17 \\
223\end{array}$ & 0 & 0 & 0 & 0 \\
\hline 45201 & & $\begin{array}{c}\text { Кредит, } \\
\text { предоставленный при } \\
\text { недостатке средств на } \\
\text { расчетном (текущем) } \\
\text { счете («овердрафт») }\end{array}$ & $\begin{array}{lll}7 & 106\end{array}$ & 3421 & 1594 & 1292 & 3475 & 1000 & 1000 & 0 \\
\hline 45204 & \multirow{5}{*}{$\begin{array}{c}\text { Кредиты, } \\
\text { предоставленные } \\
\text { негосударственным } \\
\text { финансовым } \\
\text { организациям }\end{array}$} & $\begin{array}{c}\text { на срок от } 31 \text { до } 90 \\
\text { дней }\end{array}$ & $\begin{array}{c}46 \\
000\end{array}$ & 54917 & $\begin{array}{c}63 \\
170\end{array}$ & $\begin{array}{c}36 \\
593\end{array}$ & 0 & 0 & 0 & 0 \\
\hline 45205 & & $\begin{array}{c}\text { на срок от } 91 \text { до } 180 \\
\text { дней }\end{array}$ & $\begin{array}{c}84 \\
924\end{array}$ & 65328 & $\begin{array}{c}96 \\
738\end{array}$ & $\begin{array}{c}55 \\
000\end{array}$ & 0 & 0 & 0 & 0 \\
\hline 45206 & & $\begin{array}{c}\text { на срок от } 181 \text { дня до } \\
1 \text { года }\end{array}$ & $\begin{array}{c}1922 \\
608\end{array}$ & $\begin{array}{c}1851 \\
380\end{array}$ & $\begin{array}{c}1793 \\
809\end{array}$ & $\begin{array}{c}1879 \\
425\end{array}$ & 7782 & $\begin{array}{c}10 \\
843\end{array}$ & 8008 & 2994 \\
\hline 45207 & & $\begin{array}{c}\text { на срок от } 1 \text { года до } 3 \\
\text { лет }\end{array}$ & $\begin{array}{c}2370 \\
884\end{array}$ & $\begin{array}{c}2466 \\
601\end{array}$ & $\begin{array}{c}2645 \\
250\end{array} \mid$ & $\begin{array}{c}2547 \\
422\end{array}$ & 120 & 240 & $\begin{array}{c}15 \\
000\end{array}$ & 0 \\
\hline 45208 & & на срок свыше 3 лет & $\begin{array}{c}10 \\
500\end{array}$ & 9972 & $9445 \mid$ & 8917 & 0 & 0 & 0 & 0 \\
\hline 45401 & \multirow{3}{*}{$\begin{array}{c}\text { Кредиты и прочие } \\
\text { средства, } \\
\text { предоставленные } \\
\text { индивидуальным } \\
\text { предпринимателям }\end{array}$} & \begin{tabular}{|c|} 
Кредит, \\
предоставленный при \\
недостатке средств на \\
расчетном (текущем) \\
счете («овердрафт») \\
\end{tabular} & 271 & 391 & 400 & 399 & 0 & 0 & 0 & 0 \\
\hline 45406 & & $\begin{array}{l}\text { Кредиты на срок от } \\
181 \text { дня до } 1 \text { года }\end{array}$ & 660 & 440 & 330 & 220 & 0 & 0 & 0 & 0 \\
\hline 45407 & & $\begin{array}{c}\text { Кредиты на срок от } 1 \\
\text { года до } 3 \text { лет }\end{array}$ & 6770 & 7120 & $\begin{array}{c}12 \\
380\end{array}$ & $\begin{array}{c}20 \\
120\end{array}$ & 0 & 0 & 0 & 0 \\
\hline
\end{tabular}




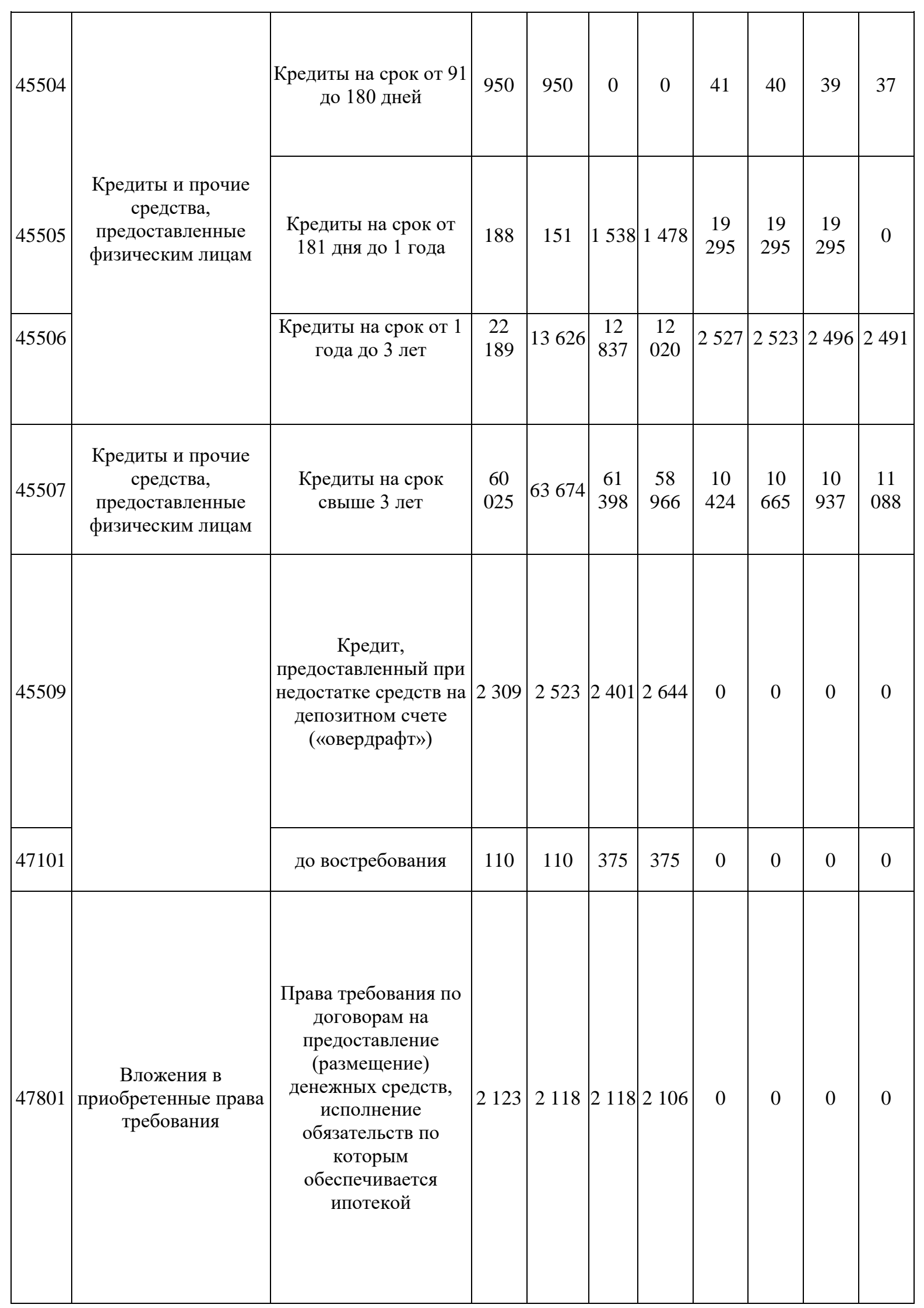


Структура портфеля депозитов банка ХХХХ (тыс. руб.)

Таблицุа 2

\begin{tabular}{|c|c|c|c|c|c|c|}
\hline \multirow{2}{*}{ Счёт } & \multirow{2}{*}{ Группа счетов } & \multirow{2}{*}{ Название счета } & \multicolumn{4}{|c|}{ Остаток по счёту } \\
\hline & & & 30.09 & 31.10 & 30.11 & 31.12 \\
\hline 42301 & \multirow{4}{*}{\begin{tabular}{|c|} 
Депозиты и прочие \\
привлеченные \\
средства физических \\
лиц
\end{tabular}} & Депозиты до востребования & 117646 & 88308 & 69078 & 58302 \\
\hline 42304 & & $\begin{array}{c}\text { Депозиты на срок от } 91 \text { до } \\
180 \text { дней }\end{array}$ & 316522 & 360839 & 367390 & 229521 \\
\hline 42305 & & $\begin{array}{c}\text { Депозиты на срок от } 181 \text { дня } \\
\text { до } 1 \text { года }\end{array}$ & 1877872 & 1474985 & 1601485 & 1582315 \\
\hline 42306 & & $\begin{array}{c}\text { Депозиты на срок от } 1 \text { года до } \\
3 \text { лет }\end{array}$ & 2639467 & 3044462 & 3190050 & 3242940 \\
\hline 42601 & \multirow{4}{*}{$\begin{array}{c}\text { Депозиты и прочие } \\
\text { привлеченные } \\
\text { средства физических } \\
\text { лиц - нерезидентов }\end{array}$} & Депозиты до востребования & 2557 & 2919 & 2947 & 2677 \\
\hline 42604 & & $\begin{array}{c}\text { Депозиты на срок от } 91 \text { до } \\
180 \text { дней }\end{array}$ & 2218 & 3558 & 3473 & 3181 \\
\hline 42605 & & $\begin{array}{l}\text { Депозиты на срок от } 181 \text { дня } \\
\text { до } 1 \text { года }\end{array}$ & 8097 & 7870 & 9559 & 8709 \\
\hline 42606 & & $\begin{array}{l}\text { Депозиты на срок от } 1 \text { года до } \\
3 \text { лет }\end{array}$ & 13394 & 13007 & 13614 & 13641 \\
\hline
\end{tabular}

В таблице 3 приведены значения ключевых показателей банковского портфеля: $V^{(t)}, \quad Y^{(t)}, P^{(t)}, k 2^{(t)}$ (объём кредитного портфеля, объём погашений по ранее размещённым кредитам, объём просроченной задолженности, коэффициент просроченной задолженности).

Таблица 3

Расчётные значения показателей $V^{(t)}, Y^{(t)}, P^{(t)}$ для банка ХХХ, руб.

\begin{tabular}{|c|c|c|c|}
\hline & на 31.10 .2017 & на 30.11 .2017 & на 31.12 .2017 \\
\hline $\mathrm{V}^{(\mathrm{t})}$ & 4607075604 & 4770102627 & 4660931379 \\
\hline $\mathrm{Y}^{(\mathrm{t})}$ & 163952241 & 224161273 & 542251775 \\
\hline $\mathrm{P}^{(\mathrm{t})}$ & 44729838 & 56896926 & 16732271 \\
\hline $\mathrm{k} 2^{(\mathrm{t})}$ & $0,97 \%$ & $1,19 \%$ & $0,36 \%$ \\
\hline
\end{tabular}

В данном случае можно утверждать, что банк XXX контролирует риск банкротства заёмщика, что позволяет поддерживать просроченную задолженность на минимальном (ниже порогового значения) уровне.

В таблице 4 представлены значения нормативов ликвидности для банка XXX на соответствующие даты. Банк выполняет все нормативы ликвидности $(H 2, H 3, H 4)$ в каждом из рассматриваемых периодов. Кроме того, банк обладает значительным запасом мгновенной и текущей ликвидности. На основании процентного превышения 
фактического значения норматива над минимальным (для $H 2$ и Н3) и максимальным (для Н4) определим свободные ресурсы банка (таблица 5).

Исходя из того, что на 31.10.2017 РН2< $<$ 33 и РН4>0, получаем, что сумма средств, которую банк может инвестировать в кредиты в ноябре, может составить объем 1566 821850 руб., в т.ч. кредиты на срок свыше 1 года - объем не более 803296000 руб. На 30.11 и 31.12.2017 максимальный объем средств, которые могут быть инвестированы в кредиты в декабре (январе), составляют 1739331800 руб. (1 622570650 руб.), в т.ч. в кредиты со сроком «от 1 мес. до года» в объеме 1567424500 руб. (1 488618500 руб.), кредиты на срок свыше года в объеме не более 880025000 руб. (812 576000 руб.).

Таблий 4

Значения нормативов ликвидности Н2, H3, Н4 для банка XXX (фактические и установленные ЦБ РФ)

\begin{tabular}{|c|c|c|c|c|}
\hline & на 31.10 .2017 & на 30.11 .2017 & на 31.12 .2017 & $\begin{array}{c}\text { Норматив, установленный } \\
\text { ЦБ РФ }\end{array}$ \\
\hline H2 & $151,23 \%$ & $158,09 \%$ & $138,88 \%$ & $\geq 15 \%$ \\
\hline H3 & $159,23 \%$ & $153,26 \%$ & $119,43 \%$ & $\geq 50 \%$ \\
\hline H4 & $51,73 \%$ & $57,44 \%$ & $35,94 \%$ & $\leq 120 \%$ \\
\hline
\end{tabular}

Таблий 5

Свободные ресурсы банка ХХХ, определённые по нормативам ликвидности, руб.

\begin{tabular}{|c|c|c|c|}
\hline & на 31.10 .2017 & на 30.11 .2017 & на 31.12 .2017 \\
\hline PH2 & 1566821850 & 1739331800 & 1622570650 \\
\hline PH3 & 1661166500 & 1567424500 & 1488618500 \\
\hline PH4 & 803296000 & 880025000 & 812576000 \\
\hline $\mathrm{HV}^{(\mathrm{t})}$ & 1566821850 & 1739331800 & 1622570650 \\
\hline
\end{tabular}

По результатам проведенных расчётов можно утверждать, что параметрическая модель оптимального управления кредитным портфелем коммерческого банка даёт адекватную оценку величины свободных ресурсов банка для инвестирования в кредиты на дату рассмотрения кредитных заявок.

Феномен финансовой устойчивости и оценка интервала устойчивости структуры оптимального кредитного портфеля КБ.

Рассмотрим следующее важное с позиции оценки финансово-экономического положения коммерческого банка приложение параметрической модели (8) - (12) оптимизации банковского портфеля, связанное с уточнением методологии оценки финансовой устойчивости коммерческого банка.

В оценках финансово-экономического состояния банковской организации понятие «финансовая устойчивость» занимает особое место. Очень часто эту категорию смешивают с понятием «финансовая надежность» банка, при том, что эти понятия концептуально различны.

Нам близка позиция авторского коллектива под руководством Т.М. Ковалевой, отстаивающего точку зрения, что финансовая устойчивость КБ - «такое состояние банка, которое обусловливает его динамическое развитие, позволяет выполнить свойственные банку функции и обеспечивает его равновесное состояние при негативном воздействии внутренних и внешних факторов [28, с.225].

Схожую с приведенной позицию отстаивает О.И. Лаврушин: ...финансовая устойчивость банка - «динамическое состояние, которое обеспечивает необходимый уровень способности к преодоление неблагоприятных воздействий внешних и внутренних факторов его поступательного развития» $[18$, с.12]. Он же следующим 
образом конкретизирует эту мысль: «Устойчивый банк - ... денежно-кредитный институт, который обладает устойчивой (развивающейся) ресурсной базой, что...выражается в достижении качества активов, стабильности доходов, ликвидности и высокого уровня управления [8, с.8].

Напротив, позиция Г.Г. Фетисова, который определяет финансовую устойчивость банка, как «способность...выполнять свои обязательства перед клиентами, кредиторами и вкладчиками и обеспечивать потребности в краткосрочном и долгосрочном кредитовании в условиях изменяющихся внешних и внутренних факторов [27, с.14], что, по нашему мнению, в большей степени характеризует не финансовую устойчивость, а надежность финансовой основы банка.

Аналогичную Г.Г. Фетисову позицию занимают О.П. Овчинникова и А.Ю.Бец, которые под финансовой устойчивостью банка понимают «способность выполнять базовые и новые функции независимо от характера внешних воздействий» [20, с.33].

Несколько в стороне от «традиционного» понимания финансовой устойчивости коммерческого банка находится интерпретация этого понятия, предложенная специалистами рейтингового агентства «Эксперт РА»:...возможность в течение длительного времени поддерживать кредитоспособность [14].

Экономическо-математическое моделирование банковской деятельности и, в частности, приведенная выше параметрическая модель оптимизации банковского портфеля позволяет взглянуть на проблематику феномена динамической устойчивости КБ с позиции традиционно используемого в анализе экономико-математических моделей инструментария оценки устойчивости оптимальных решений.

В нашем случае под устойчивостью (интервальной) структуры банковского портфеля (но не устойчивостью КБ!), полученного в результате решения двухуровневой оптимизационной задачи (1) - (7), (8) - (12), будем понимать интервалы изменений экзогенных (неуправляемых) параметров, в пределах которых возможен выбор вектора эндогенных (управляемых) параметров кредитно-инвестиционной деятельности банка, обеспечивающий сохранение структуры оптимального банковского портфеля и прогнозируемое (в пределах интервала устойчивости) изменение показателей его доходности и риска.

Для оценки интервала устойчивости структуры оптимального банковского портфеля по вектору экзогенных параметров может быть предложен численный метод, основанный на алгоритмах оценки устойчивости оптимального решения задачи математического программирования (в данном случае, нелинейного), представленных в работах М. Мину [19] и М.А. Халикова [29].

Заключение. Существенной особенностью полных моделей банка в статичном и динамическом вариантах является жесткая «привязка» к условиям кредитноинвестиционной деятельности банковских организаций, определяемым требованиями регулятора (Центрального банка) и параметрами финансовых рынков (средние по рынку процентные ставки и спрос на кредиты с учетом объемов, цен и сроков кредитования). Однако реальная банковская практика демонстрирует необходимость оперативного учета в моделях кредитно-инвестиционной деятельности коммерческого банка изменчивости экзогенных и эндогенных параметров, влияющих на структуру и элементный состав оптимального банковского портфеля.

Интенсификация операционной, кредитно-инвестиционной и др. видов банковской деятельности в условиях внедрения в банковскую практику современных компьютерных технологий и средств автоматизации расчетов объективно способствует повышению оценок банковского портфеля и качества решений по его управлению. Используемый банками инструментарий математических моделей и программных средств должен быть адекватным современным условиям их деятельности и обладать потенциалом гибкого реагирования на изменение этих условий. Предложенный подход к параметрическому моделированию оптимального банковского портфеля и результаты его адаптации в 
практической деятельности исследуемого коммерческого банка продемонстрировали соответствие этому требованию.

$$
\text { *** }
$$

1. Антиколь А.М., Халиков М.А. Нелинейные модели микроэкономики: Учебное пособие. М.: ФГБОУ ВПО «РЭУ им. Г.В.Плеханова», 2011. $156 \mathrm{c.}$

2. Анциборко К.В., Халиков М.А. Теоретические аспекты анализа структуры капитала инвестиционного проекта и выбора ставки дисконтирования// Современные аспекты экономики. 2005. № 11 (78). С. 122-136.

3. Булышева Т.С., Милорадов К.А., Халиков М.А. Динамические модели производственных инвестиций: Учебное пособие. М.: Изд-во Рос.экон.акад. 2002. 118 с.

4. Белоглазова Г. Н., Кроливецкая Л.П. Банковское дело. Организация деятельности коммерческого банка. М.: Высш. образование, 2008. 278 с.

5. Белотелова Н. П. Деньги. Кредит. Банки: учебник. М.: Издательско-торговая корпорация «Дашков и $\mathrm{K}^{\circ} \gg .2013 .400 \mathrm{c}$.

6. Бородин А.В. Математические модели и алгоритмы управления кредитным портфелем коммерческого банка. дис. на соис. уч. ст. к.э.н. Москва. МЭСИ. 1999. 167 с.

7. Бренд Р. Банковская система и контроль за банковской деятельностью в условиях рыночной экономики. Мюнхен, 1994. 426 с.

8. Буруханова Т.Д. Оптимизация кредитного портфеля коммерческого банка. дис. на соис. уч. ст. к.э.н. Москва. Фин. Акад. при Правительстве РФ. 2003 г. 140 с.

9. Гаджиагаев (Горский) М.А., Халиков М.А. Динамическая модель оптимального управления кредитным портфелем коммерческого банка с дополнительным критерием ликвидности временной структуры активов-пассивов// Путеводитель предпринимателя. 2016. №29. С.72-85.

10. Герасимова Е.Б. Феноменология анализа финансовой устойчивости кредитной организации // Финансы и статистика, 2006. №2. С. 2 - 5 .

11. Егорова Н.Е., Смулов А.М. Предприятия и банки: Взаимодействие, экономический анализ: учебнопрактическое пособие. М.: Дело. 2002. 454 с.

12. Жукова Е.Ф., Эриашвили Н.Д. Банки и небанковские кредитные организации и их операции. М.: ЮНИТИ-ДАНА, 2012. 559 с.

13. Зайцева М.В. Оптимизация кредитного портфеля коммерческого банка. дис. на соис. уч. ст. к.э.н. Москва. РГСУ. 2014. 161 с.

14. Комардина О.М., Велиева И.С., Самиев П.А. Финансовая устойчивость российских банков: размер или специализация? // Рейтинговое агентство «PA Эксперт» [Электронный ресурс]. URL https://raexpert.ru/researches/banks/bank7 (дата обращения: 08.11.2018).

15. Киселева И.А. Система математического моделирования банковской деятельности в переходной экономике. дис. на соис. уч. ст. д.э.н. Москва. МЭСИ, 2000. 484 с.

16. Коган В.И. Моделирование процессов управления рыночными структурами в условиях переходного периода (на примере коммерческих банков). автореф. дис. на соис. уч. ст. к.э.н., 1994. 18 с.

17. Криночкин Д.Л. Управление риском несбалансированной ликвидности коммерческого банка. дис. на соис. уч. ст. к.э.н. - М.: Фин. Акад. при Правительстве РФ. 2002 г. 198 с.

18. Лаврушин О.И. Деньги, кредиты, банки. М.: Кнорус. 2014. 448 с.

19. Мину М. Математическое программирование. Теория и алгоритмы. М.: Наука. 1990. 488 с.

20. Овчинникова О. П., Бец А. Ю. Основные направления обеспечения динамической устойчивости банковской системы//Финансы и кредит. 2012. № 22. С. 33.

21. Панова Г.С. Кредитная политика коммерческого банка. М.: ИКЦ "ДИС". 1997. 464 с.

22. Пуртиков В.А. Постановка задачи оптимизации выбора кредитного портфеля//Вестник НИИ СУВПТ. Красноярск: НИИ СУВПТ. 1999. № 2. С.145-159.

23. Роуз Питер С. Банковский менеджмент. М.: Дело. 1997. 768 с.

24. Синки Джозеф Ф., мл. Управление финансами в коммерческих банках. Пер. с англ.: под ред. Р.Я. Левиты, Б.С. Пинскера. М.: Catallaxary. 1994. 957 с.

25. Софронова В.В. Финансовая устойчивость банка: учеб. пособие. 2-е изд., перераб. и доп. Н. Новгород: ФГОУ ВПО «ВГАВТ». 2015. $120 \mathrm{c}$.

26. Уразаева Т.А. Управление ценообразованием депозитов коммерческого банка. дис. на соис. уч. ст. к.э.н. Москва. МЭСИ. 2000. 129 с.

27. Фетисов Г.Г. Устойчивость банковской системы и методология ее оценки. М.: Экономика. 2003. 400 c.

28. Финансы, деньги, кредит, банки: учебник / коллектив авторов: под ред. Т.М. Ковалевой. М.: КНОРУC. 2014. $256 \mathrm{c}$.

29. Халиков М.А. Дискретная оптимизация планов повышения надежности функционирования экономических систем // Финансовая математика. Сб. ст. М.: МГУ. 2001. С. 281-295. 
30. Халиков М.А., Антиколь А.М. Методы учёта трансакционных издержек операций фондового рынка //Вестник Российского экономического университета. 2012. №2. С.53-59.

31. Busch, A. Banking regulation and globalization. Oxford University Press, 2009. P. 282.

32. Klin M. Theory of the banking firm. J.Money. Credit and banking. 1971. May. P. 205-218.

33. Maximov D.A., Khalikov M.A. Prospects of institutional approach to production corporation assets assessment. Aktual Problems of Economics. 2016. vol. 183. no. 9. P. 16-25.

34. Murphy N.D. Costs of banking activities: interactions between risk and operating costs: ii comment. J. Money. Credit and Banking. 1972. Aug. P.205-218.

35. Sealey C.W. Valuation, capital structure, and shareholder unanimity for depository financial intermediates. J. Finance. 1983, June. P. 1139-1154.

Тесленко И.Б., Соловьева О.В.

Новые тенденции в подборе и отборе персонала в условиях цифровизации

ФКОУ ВО «Владимирский юридический институт Федеральной службы исполнения наказаний»

(Россия, Владимир)

doi: 10.18411/scienceconf-05-2019-47

idsp: scienceconf-05-2019-47

\section{Анотация}

Современный этап развития социально-экономических систем характеризуется появлением новых товаров, услуг, процессов, технологий, форм взаимодействия и др. Субъекты экономики фокус своего внимания все больше устремляют не внутрь организации, а вовне, поскольку отношения с внешней средой открывают новые возможности, позволяют использовать дополнительные преимущества. В статье рассматриваются новые подходы к управлению персоналом и возможность внедрения инноваций в практику управления организацией. Концепция открытых инноваций, благодаря развитию информационных технологий, появлению Интернета стала активно распространяться, инновационные идеи стали выходит за пределы одной организации, одного города, одной страны.

Ключевые слова. Современные тенденции в управление персоналом, современные кадровые технологии, инновации, инновационные идеи, краудсорсинг, цифровые технологии, цифровизация, крауд-технологии, краудфандинг, аутплейсмент, краудректуринг

\section{Abstract}

The current stage of development of socio-economic systems is characterized by the appearance of new products, services, processes, technologies, forms of interaction and other economic Actors focus their attention more and more direct not inside the organization but outside, as the relationship with the external environment, open new opportunities, allow you to use additional benefits. The article discusses new approaches to personnel management and the possibility of innovation in the practice of organization management. The concept of open innovation, thanks to the development of information technology, the emergence of the Internet has become actively spread, innovative ideas have become beyond one organization, one city, one country.

Keyword. Modern trends in personnel management, human technology, innovation, innovative ideas, crowdsourcing, digital technologies, digitization, crowd-technology, crowdfunding, outplacement, krautrocking

В современных условиях роль человеческого фактора в эффективной и результативной работе организаций значительно возросла. Наряду с технологиями и информацией, жизнеспособность и перспективное развитие любой организации во многом обеспечивается профессионализмом и квалификацией сотрудников. Возрастающее значение профессиональной подготовки в последние тридцать лет привели 
к тому, что прогрессивно работающие компании, взяли на себя заботу и ответственность частично за профессиональную подготовку и полностью за повышение квалификации своих сотрудников. Постоянное развитие организации под влиянием инновационных идей, которые генерирует персонал и реализует персонал, делает привлечение и отбор наиболее профессиональных, квалифицированных работников первостепенной задачей руководства компании и отделов по управлению персоналом. Следует отметить, что на современном этапе развития информационных технологий и управленческой науки, любое предприятие/организация не является закрытой, для нововведений и инноваций, системой и ищет новые современные подходы к совершенствованию управленческих процессов, особенно в вопросах управления персоналом. Благодаря развитию информационных технологий, появлению Интернета стала активно распространяться концепция открытых инноваций. Инновационные идеи стали выходит за пределы одной организации, в обсуждении и выдвижении нестандартных решений стали участвовать специалисты других организаций и предприятий, других городов и стран, смежных направлений деятельности. В условиях развития цифровой среды субъекты экономики начали пользоваться преимуществами новых технологий и сервисов, стали активно втягиваться в новые социальные взаимодействия. Одной из таких новых технологий, которая стала распространяться с нулевых годов XXI, является технология краудсорсинга (от анг. «crowd» - толпа и «sourcing» - использование ресурсов). Краудсорсинг, как социальная технология, предполагает использование способностей, знаний, интеллекта, креативных навыков большого количества людей для решения разных вопросов и проблем в ходе совместной он-лайн работы на специализированной интернет-платформе. Краудсорсинг - это пример использования коллективного разума в разных областях знания при выборе лучшего решения проблемы из множества альтернатив. Современный этап развития социально-экономических систем характеризуется появлением новых социальных процессов, технологий, форм взаимодействия и др. Субъекты экономики фокус своего внимания все больше устремляют не внутрь организации, а вовне, поскольку отношения с внешней средой открывают новые возможности, позволяют использовать дополнительные преимущества. В широком смысле краудсорсинг позволяет за счет «толпы» решать многие управленческие задачи. В узком смысле слова краудсорсинг, включает поиск инновационных путей решения задач инициатора проекта. В большинстве случаев он предоставляет возможность для инновации, но не реализует саму инновацию. Технология краудсорсинга используется при обмене знаниями, разработке идей и концепций, сборе денежных средств для реализации интересных и социально-значимых проектов, голосовании, работе над контентом, оценке разных предложений и др. Не случайно, краудсорсинг определяют как, один из видов социальных технологий, который на основе модели открытых инноваций в целях получения нового знания, относительно инновационных путей развития субъекта-инициатора, позволяет вовлекать в данный процесс с помощью Интернета, социальных сетей и специализированных компьютерных платформ неопределенный круг лиц из внешней и внутренней среды организации, используя их знания и профессиональный опыт.

Цифровая платформа создается для многостороннего взаимодействия пользователей по обмену информацией в целях оптимизации бизнес-процессов, а также снижения общих транзакционных издержек и повышения эффективности цепочек поставок товаров и оказания услуг. Несколько цифровых платформ объединяются в экосистему, в рамках которой создаются условия для обмена цифровыми сервисами и приложениями. Специалисты считают, что чаще всего краудсорсинг в организации, - это проявление так называемого idea management (управление идеями), поскольку именно они, будучи реализованными, способны увеличить прибыль компании. Краудсорсинг чаще всего является безвозмездным процессом. Тем не менее, многие компании стремятся поощрять людей, выдвинувших действительно стоящее предложение. Краудсорсинг - это вызванное новыми реалиями XXI века развитие технологии 
аутсорсинга, при которой, благодаря интеграционным процессам, часть функций деятельности организации передается сторонним организациям с целью экономии затрат. Краудсорсинг по сути - это продолжением традиций аутсорсинга в условиях цифровой экономики, снявшей барьеры времени и пространства. В отличие от аутсорсинга, он задействует значительное большее количество заинтересованных людей из внешней среды, предлагает множество альтернатив, рождает в ходе дискуссий инновационные идеи, малозатратен, несмотря на значительное количество участников, значительно сокращает сроки решения проблем, повышая тем самым эффективность функционирования организации.

Сфера применения крауд-технологий весьма обширна. С их помощью бизнес может, например, продвигать свой бренд; совершенствовать дизайн сайта, организовывать взаимодействие с клиентами через онлайн-опросы и форумы; привлекать ресурсы, например, капитал (краудфандинг, от анг. «crowd» - толпа и funding финансирование), трудовые ресурсы (краудрекрутинг) и др. Привлечение ресурсов для бизнеса в современных условиях является особенно важным.

Остановимся на рассмотрении краудрекрутинга. Ни для кого не секрет, что результаты деятельности организаций зависят от ее работников. Каждая организация стремится найти самых лучших работников. Хороший работник - это тот, кто добросовестно выполняет все свои функции. Лучший работник - это тот, кто старается научиться делать что-то новое, проявляет инициативу, легко принимает перемены, умеет решать проблемы, не отказывается от новых обязанностей и т.д. Сейчас подбором персонала в организациях и на предприятиях занимаются отделы кадров, а также специализированные организации - службы занятости и рекрутинговые агентства. Рекрутинг - это бизнес-процесс по подбору и отбору специалистов для компаниизаказчика. Поиском и отбором персонала в соответствии с заданными требованиями работодателя стали заниматься компании в Германии еще в XIX веке, позже эта деятельность стала практиковаться во Франции и Великобритании. В США после Второй мировой войны появилось первое рекрутинговое агентство. За долгие годы рекрутинг развивался и совершенствовался. Сейчас он представляет самостоятельный вид бизнеса. Рекрутинг реализует разные виды услуг, например:

-«Целевой поиск» или «охота за головами» - это услуга по поиску наилучшей кандидатуры на руководящий пост.

- Аутплейсмент - услуга по трудоустройству персонала, уволенного из компаниизаказчика в соответствии с установленными сроками и определенными условиями. В результате процедура увольнения значительно облегчается, компромиссные решения принимаются гораздо быстрее. Оплачивает данную услугу компания-заказчик.

- Лизинг персонала - услуга, в соответствии с которой агентство предоставляет компании-заказчику необходимого сотрудника на определенный срок для выполнения работы в соответствии с занимаемой должностью. Взаиморасчеты между сторонами при этом выглядят следующим образом: компания-заказчик выплачивает компанииарендодателю зафиксированный в ранее подписанном договоре гонорар, а та в свою очередь оплачивает труд «сданного в аренду» сотрудника.

- Онлайн рекрутинг - привлечение квалифицированного персонала или нахождение соискателем нужной вакансии с помощью веб-сайтов . В России служба Human Resourses ON-Line (HRO), созданная в мае 1996 г. на платной основе, стала предоставлять возможность размещать вакансии от организаций и кадровых агентств. Затем был запущен аналогичный интернет ресурс PointJob (www.pointjob.ru) и началось развитие электронного рекрутмента. Заработали сайты zarplata.ru, superjob.ru, hh.ru, job.ru, rosrabota.ru, rabota.ru, bankir.ru и др. Некоторые из них сначала были бесплатными, а затем стали работать на платной основе. Онлайн-рекрутинг осуществляют: Job-cайты (предназначены для поиска работы и сотрудников), Social media (социальные сети: vk.com, facebook.com, odnoklassniki.ru, LinkedIn.com, moikrug.ru и др.; блоги, форумы и 
др.), технологии он-лайн оценки кандидата (тестирование, интервьюирование по Skype, видео CV и др.), специализированные сайты компаний для привлечения кандидатов (job.svyaznoy.ru, rabotavmcdonalds.ru, job.mvideo.ru и т.д.), страницы с информацией об открытых вакансиях на корпоративных сайтах, он-лайн дневники (блоги), в которых рассказывается о корпоративной культуре, организационной структуре, проблемах, задачах компании. В последние время возможности онлайн-рекрутинга расширяются и совершенствуются. За рубежом и в России заговорили о технологии краудрекрутинга. Это не просто способ найма работников, аналогичный онлайн-рекрутингу, когда информационные технологии помогают компании экономить время на поиск кандидатов и сократить на это затраты. Это нечто большее. Хотя без цифровых технологий ни в первом случае, ни во втором не обойтись.

Краудрекрутинг (от анг. «crowd» - толпа и recruiting - подбор на определенные должности, вербовка) - это способ найти и нанять работника путем оценки его качеств, реальных возможностей и способностей при выполнении проекта, предложенного компанией. Это модель распределенного решения задач силами группы людей, где лучшие решения выбираются из большого количества вариантов. Если краудсорсинг, как таковой, нацелен на непосредственное решение бизнес-задачи, то цель краудрекрутинга оценка и отбор лучших сотрудников из достаточно большого числа кандидатов .

Характерным отличием краудрекрутинга от способов отбора кандидатов на работу является полноценное вовлечение участников проекта в решение поставленных задач, благодаря чему у них появляется возможность в короткие сроки показать себя с совершенно разных сторон, максимально раскрыв свой потенциал. Важным здесь является не само решение бизнес-задачи, а поиск сотрудников, которые заинтересованы в решении этой бизнес-задачи .

Краудректуринг - это применение технологии краудсорсинга (вовлечение большого количества людей) при непосредственном участии профессионалов в сфере рекрутинга, которые могут благодаря работе претендентов на крауд-платформах квалифицированно оценить потенциального сотрудника с учетом интересов и запросов работодателя. Не стоит забывать, что кандидатов на вакансии благодаря социальным сетям может быть бесчисленное множество. А работодатель может выбрать самых талантливых, предлагающих интересные варианты решения реальных задач. Это возможно, т.к. предлагаемый проект предполагает не только индивидуальную, но и командную работу, а также взаимодействие с работодателем. Работодатель, так же в режиме онлайн, может отслеживать действия и предложения каждого кандидата и общаться с ним путем анкетирования, участия в видео-конференциях, знакомства с резюме кандидата и др.

Преимуществом краудрекрутинга является и то, что в процессе работы кандидата над проектом, работодатель многое может узнать о способностях претендентов, их умениях или неумениях действовать в разных ситуациях. Самим кандидатам также бывает интересно участвовать в проекте: их охватывает азарт решить проблемы в условиях жесткой конкурентной среды широкого круга участников. Важным является еще и то, что и работодатель и кандидаты заинтересованы в совместной работе, они ближе знакомятся друг с другом в процессе работы, готовы слышать друг друга, договариваться о наиболее приемлемых для всех условиях труда и ее оплаты. В результате снижается загруженность работников HR-службы предприятия, или отпадает необходимость в привлечении сторонних рекрутинговых агентств, сокращается стоимость отбора каждого из кандидатов.

Сравнивая краудсорсинг и краудрекрутинг, специалисты говорят, что краудсорсинг относится к открытым торговым площадкам, в основном используемым рекрутерами и хедхантерами для найма постоянного персонала. Интерфейс платформ часто позволяет исполнителям общаться напрямую с рекрутинговыми профессионалами и работодателями. Краудрекрутинг - это частная торговая площадка для кураторов 
рекрутинга, специализирующихся на найме определенных специалистов. Модель интересна тем, что соединяет в себе масштабированность и нишевую направленность с использованием глобальных рекрутинговых компаний, гарантирующих 100\% успешный результат. Краудрекрутинг интегрируется в любую существующую программу MSP. Программное обеспечение краудрекрутинговых платформ позволяет рекрутерам получать запросы и отправлять собственные предложения на рассмотрение. Поставщики краудрекрутинговых услуг обеспечивают качество и невысокий уровень риска.

Краудрекрутинг - достаточно новая технология. Ее, например, использует платформа BrainForce или FuturUS для реализации краудсорсинговыех проектов. В процессе из осуществления собирается разная информация об участниках: как формализуемая (рейтинги, достижения и т. д.), так и неформализуемая (качество предложений, глубина проработки темы, умение работать с чужим контентом и т. д.). С ее помощью можно выявить скрытые компетенции участников, выделить наиболее перспективных сотрудники, провести объективную оценку персонала. По итогам проекта принимаются соответствующие управленческие решения.

Задача работодателя в краудрекрутинге - создать актуальный проект, сделать его интересным для участников, а также предложить систему поощрений для лидеров этого «соревнования». Однако, самое важное - это не ограничивать участников ни в чем, чтобы процесс реализации проекта был творческим и участники максимально раскрыли свой потенциал. Они должны показать владение общими знаниями, специфическими знаниями (связаны с отраслью, видом деятельности, продуктом и др.), умение работать с информацией, проявить индивидуальные черты (усидчивость, грамотность, пунктуальность, частоту проявления инициативы и др.), навыки работы в коллективе (может быть лидерские качества). По завершении проекта работодателю останется лишь разослать тем, кто его заинтересовал, приглашения на финальное собеседование, или же предложение занять вакантное место.

В России технология краудрекрутинга была применена в 2012 г. компанией Witology по заказу госкорпорации «Росатом» в ходе реализации уникального проекта «ТеМП 2012». Проект был направлен на отбор 100 специалистов для разных направлений деятельности «Росатома». Проект выполнялся поэтапно: привлечение кандидатов (было привлечено 870 человек), тестирование на соответствие кандидата требованиям корпорации; профессиональное тестирование отдельными предприятия корпорации, где соискатели предлагали свои оригинальные идеи и демонстрировали командные навыки работы; выявление лучших предложений участников; финальный отбор - подготовка презентации с описанием решения задач предприятия. В конце проекта финалисты ездили на стажировку в компании-участницы проекта, чтобы понять специфику их работы. При традиционном рекрутинге на это потребовалось бы около полугода. Данный проект на основе краудрекрутинга занял всего месяц. Наряду с выявлением самых креативных и знающих кандидатов, краудрекрутинг позволил сформировать определенный кадровый резерв молодых специалистов, познакомить многих претендентов с компанией и спецификой ее работы.

Краудрекрутинг имеет свои преимущества и ограничения. Дополнительно к тем преимуществам, которые были определены выше - скорость отбора и экономия затрат следует отметить, что именно он-лайн формат очень востребован современными молодыми людьми, он им понятен и его преимущества им очевидны. Поэтому выпускники вузов разных специальностей - это основная аудитория крудрекрутинговых проектов. Речь идет о специалистах с востребованным функционалом - бизнес-аналитики, маркетологи, логисты, инженеры, ИТ-специалисты и др. Вряд ли подойдет эта технология при подборе водителя, секретаря, а также кандидатов для редких профессий. Проект объединяет людей разных возрастов и сфер деятельности, что дает возможность каждому увидеть методы и приемами его решения разными кандидатами и пополнить ими свой багаж знаний и навыков. Вместе с тем не все руководители, особенно в регионах, готовы 
использовать этот формат и предпочитают традиционные методы набора персонала. Традиционные методы поиска работы часто предпочитают и высококвалифицированные специалисты . Существует категория соискателей, которые готовы рассматривать предложения по работе, но не готовы сами активно их искать. В таком случае только творческий подход рекрутера в выборе методов поиска и его активность и инициативность может позволить отыскать кандидата необходимой квалификации. Что касается подбора руководителей высшего звена, то, как правило, они не прибегают к помощи Job-сайтов. Они предпочитают не афишировать своё намерение поменять работодателя и избежать снижения собственной стоимости на рынке труда: есть мнение, что хорошие менеджеры не ищут работу, а их приглашают собственники бизнеса. Аналогичная ситуация с опубликованной в открытых источниках топовой вакансией. Поиск таких профессионалов - это искусство, подвластное только человеку, может быть и вооружённого интернетом, но вряд ли НН или Superjob. Замечено, что чем выше статус предполагаемой позиции, тем важнее становится понятие личностной совместимости кандидата и руководителя. Опять же такая задача под силу только опытному рекрутеру, способному полагаться не на тесты в интернете и отклики на јob-портале, а на собственные интеллектуальные инструменты оценки людей, опыт и интуицию.

В принципе, деперсонификация процесса подбора персонала лишает его гибкости, и может снижать его эффективность .

Не так широко распространен краудрекрутинг в России, по мнению Исследовательского центра портала Superjob.ru, потому, что достаточно часто работодатели хотят именно личного контакта с кандидатом, т.к. для них важны разные мелочи, такие как внешний вид, стиль одежды, манера поведения и т.д. Он-лайн работа позволяет исключить субъективизм, но сам претендент - не робот, важную роль играют и личные взаимоотношения работодателя и будущего работника.

Дальнейшее развитие технологии краудрекрутинга заключается в совершенствовании обратной связи. Краудплатформа фиксирует общение людей, работу в команде, выдвижение идей, кого и скольких отобрали по завершении проектов и т.д. А вопросы как справляются с работой отобранные кандидаты, сколько из них «прижилось» в компании, сколько уволилось и как быстро - остаются открытыми. С этой точки зрения эффективность технологии не определена. Получение обратной связи от работодателей, позволит сопоставить их с накопленными данными о поведении кандидатов на платформе во время реализации проекта, сделать прогнозы по поведенческим моделям и предоставить соответствующие рекомендации работодателям. В любом случае количество сотрудников, не прошедших испытательный срок, должно уменьшиться, так как многие спорные вопросы краудрекрутинг позволяет решить еще до формального заключения трудового договора .

Как отмечалось выше, краудрекрутинг предполагает использование интернетплатформ, поэтому стоимость его достаточно высока, а значит не все работодатели, особенно владельцы малого и среднего бизнеса могут воспользоваться этой технологией. Это тоже сдерживает внедрение крауд-технологии в практику отбора персонала в нашей стране . Однако краудрекрутинг может использоваться не только при отборе кандидатов на вакансии, но и при необходимости решения какой-то задачи внутри компании. Таким образом, эффективно задействуется творческий потенциал работающего персонала. Это особенно актуально для крупных корпораций, где нередко подающие надежды сотрудники увольняются из-за малой востребованности своих умений и навыков. Сотрудники компании получают возможность проявить себя и тем самым начать подругому относиться к своей работе, а позже, возможно, и продвинуться вверх по карьерной лестнице. Что касается клиентов компании и сторонних респондентов, то они получают возможность стать участниками создания товара или услуги, которые им интересны . 
Подводя общий итог, следует отметить, что развитие информационных технологий меняет современный мир, открывает дополнительные возможности для появления новых взаимосвязей и взаимоотношений субъектов рынка. Интернет способен объединить усилия многих заинтересованных людей, быстро и экономно решая ту или иную проблему.

Одной из современных технологий в условиях цифровой экономики стал краудсорсинг, использующий мудрость толпы при решении разнообразных задач. Развитие крауд-технологий привело к появлению одной из его разновидностей краудрекрутингу. Ее возможности чрезвычайно широки: преодолевает географические расстояния, экономит время и затраты на поиск кандидатов на вакансию нужного специалиста компании. Однако, имея существенные преимущества, технология краудрекрутинга в полной мере пока не может заменить личного человеческого общения рекрутера с соискателем. Поэтому в настоящее время есть необходимость на начальных этапах отбора использовать краудрекрутинг, а на завершающем этапе отбора - общение с опытным профессионалом рекрутером. Такой подход можно использовать пока не будет налажена обратная связь с работодателями. Обработка полученных от них данных позволит создать модели выбора кандидата на основе тех или иных поведенческих признаков. Дальнейшее развитие краудрекрутинга может сделать эту технологию эффективной и весьма перспективной при отборе персонала в XXI веке.

$$
\text { *** }
$$

1. Idea management и краудрекрутинг. [Электронный ресурс] - Режим доступа: http://www.sergievposad.ru/useful/?ID=18134

2. Бобко А. Краудрекрутинг. Поиск людей через поиск идей. [Электронный ресурс] - Режим доступа: https://witology.com/blog/company/264/

3. Горюнова О. Одним махом убить двух зайцев - именно такой результат обещает новая технология подбора персонала. [Электронный ресурс] - Режим доступа: https://bankir.ru/publikacii/20150316/prizhivetsya-li-u-nas-kraudrekruting-10006171/

4. Краудрекрутинг - краудсорсинговая модель найма рабочей силы [Электронный ресурс] - Режим доступа: http://forumbusiness.net/showthread.php?t=27323

5. Краудрекрутинг - новая технология массового поиска талантов. [Электронный ресурс] - Режим доступа: http://iinsider.biz/

6. Краудрекрутинг как метод поиска кандидатов. [Электронный ресурс] - Режим доступа: http://hrportal.ru/blog/kraudrekruting-kak-metod-poiska-kandidatov

7. Краудрекрутинг. [Электронный ресурс] - Режим доступа: http://ci-systems.ru/ocenka-i-poisk-personala

8. Краудсорсинг vs. Краудрекрутинг: основные сходства и различия. [Электронный ресурс] - Режим доступа: http://crowdsourcing.ru/article/kraudsorsing_vs_kraudstaffing_osnovnye_sxodstva_i_razlichiya; https://www.hrhome.ru/articles/razvitiye-kraudrekrutinga-perspektivy-rosta-v-rossii.htm

9. Краудсорсинг, краудрекрутинг и краудфандинг в системе подбора персонала. [Электронный ресурс] - Режим доступа: https://studref.com/453540/menedzhment/kraudsorsing_kraudrekruting_kraudfanding_sisteme_podbora_pe rsonala

10. Лихачев Е.Ф. Краудсорсинг, как новое явление в экономике. Его социоинновационная природа и классификация // Интернет-журнал «НАУКОВЕДЕНИЕ» Том 8, №1 (2016) http://naukovedenie.ru/PDF/76EVN116.pdf (доступ свободный). Загл. с экрана. Яз. рус., англ. DOI: 10.15862/76EVN116. [Электронный ресурс] - Режим доступа: https://cyberleninka.ru/article/n/kraudsorsing-kak-novoe-yavlenie-v-ekonomike-egosotsioinnovatsionnaya-priroda-i-klassifikatsiya

11. Самое важное на предприятии - это персонал. [Электронный ресурс] - Режим доступа: https://1popersonalu.ru/info/personal-eto.html

12. Симанова И. «Реальный» рекрутинг и интернет-рекрутинг: за и против. [Электронный ресурс] Режим доступа: http://aviconn.com/press/realnyiy-rekruting-i-internet-rekruting-za-i-protiv.html

13. Услуга рекрутинга персонала - что это такое? [Электронный ресурс] - Режим доступа: http://znaydelo.ru/personal/trudoustroystvo/rekruting.html

14. Что такое рекрутинг. [Электронный ресурс] - Режим доступа: http://hr-portal.ru/article/chto-takoerekruting 


\section{Третьяков О.В. \\ Методика комплексной оценки корпоративной социальной ответственности российской компании}

ООО "ЛУКОЙЛ-ПЕРМЬ"

(Россия, Пермь)

doi: 10.18411/scienceconf-05-2019-48

idsp: scienceconf-05-2019-48

Разработка и совершенствование теории корпоративной социальной ответственности (КСО) поставила перед научным сообществом проблему, связанную с измерением совокупного вклада компании в социально-экономическое развитие общества. Суммарный вклад бизнеса в благополучие местного сообщества может измеряться различными методами с использованием как количественных, так качественных критериев, однако в настоящее время не существует единых критериев такой оценки, в результате чего ни один из них не является универсальным [3].

Предлагаемая методика основывается на комплексном анализе уровня и характера удовлетворенности заинтересованных групп. Она построена на базе известного подхода к оценке корпоративной социальной ответственности, заключающейся в сопоставлении текущих показателей деятельности с научно обоснованными социальными ориентирами или нормативами. Поддерживая указанный подход, мы предлагаем распространять этот алгоритм действий на другие факторы, оказывающие влияние на уровень развития корпоративной социальной ответственности.

Методика комплексного подхода позволяет достоверно определить уровень социальной ответственности для каждой заинтересованной группы, а также выявить общий интегральный показатель уровня развития социальной ответственности для всей корпорации. Методика включает следующие основные разделы:

1) работники организации, включенные в данную деятельность;

2) органы государственной власти и местного самоуправления;

3) потребители;

4) бизнес-партнеры корпорации.

Каждый раздел состоит из подразделов, включающих перечень параметров и показателей для определения уровня социальной ответственности по каждой из вышеназванных групп.

При использовании данной методики выявленные параметры по каждому компоненту сравниваются с нормативом или социальным ориентиром. Близость фактического и нормативного показателей свидетельствует о высокой степени социальной ответственности в данной группе. По такой же схеме определяется степень достижения каждого показателя уровня социальной ответственности как внутри каждой группы, так и общий интегральный показатель социальной ответственности компании.

Сегодня в международной практике используются так называемые индексы корпоративной социальной ответственности с помощью которых осуществляется оценка корпоративной социальной ответственности компаний, а также составляются рейтинги социально ответственных компаний. Среди отечественных разработок в сфере оценки эффективности корпоративного социального инвестирования выделяется прикладная равновесная модель, включающая совокупность элементов, связанных с обеспечением, выполнением и оценкой результативности программ и проектов по социальному инвестированию [6, с. 30].

Существующие различия в трактовке компаниями сущности корпоративных социальных инвестиций ведут к недостоверности оценки объемов социальных инвестиций в стране и показателей их эффективности [2].

Достоверная оценка эффективности корпоративного социального инвестирования возможна на основе построения индексов социальных инвестищий. Количественный и 
качественный индексы социальных инвестиций позволяют дать общую оценку масштабов и тенденций в сфере социального инвестирования.

В ходе выяснения количественного аспекта данной проблемы осуществляется непосредственная оценка финансовых затрат корпорации на социальные программы и проекты. Соответственно, основой данного подхода выступают количественныле индексы coииальных инвестищий. Количественные индикаторы учитывают диагностику абсолютной и относительной величин денежных сумм, выделяемых корпорациями на социальные программы и проекты.

Качественные характеристики полноты и комплексности социальных инвестиций, оцениваются при помощи качественных индексов социальных инвестиций. Эти индексы показывают существующую степень диверсификации социальных инвестиций, выявляют уровень организационной поддержки и информационного обеспечения социальной деятельности корпораций.

В настоящее время разработаны и внедряются три разновидности количественного индекса социальных инвестиций: 1) величина социальных инвестиций компании, приходящаяся на одного работника $(I L) ; 2)$ отношение социальных инвестиций компании к валовому объему продаж $(I S) ; 3)$ удельный вес социальных инвестиций в балансовой прибыли компании (IP).

1. Количественные индексы социальных инвестиций:

a) Индекс удельных социальных инвестиций $I L$ - это отношение затрат на социальные цели на одного работника. Формула данного индекса выглядит так:

$$
\boldsymbol{I} \boldsymbol{L}=\frac{\sum_{i=1}^{n} C_{i}}{\sum_{i=1}^{n} L_{i}}
$$

где $C_{i}$ - объем социальных инвестиций $i$-й компании (включая добровольные и обязательные затраты на социальные программы и проекты); $L_{i}$ - среднесписочная численность работников; $n$ - число компаний.

б) Доля социальных инвестиций компаний в валовом объеме продаж $I S$ (единица измерения - проценты). Формула данного индекса выглядит так:

$$
\boldsymbol{I S}=\frac{\sum_{i=1}^{n} C_{i}}{\sum_{i=1}^{n} S_{i}}
$$

где $C_{i}$ - объем социальных инвестиций $i$-й компании; $\mathrm{S}_{i}$ - валовой объем продаж $i$-й компании; $n$ - число компаний.

в) удельный вес социальных инвестиций в балансовой прибыли компании IP (единица измерения - проценты). Данный индекс определяется по формуле, аналогичной расчету индекса $I S$ :

$$
\boldsymbol{I P}=\frac{\sum_{i=1}^{n} C_{i}}{\sum_{i=1}^{n} P_{i}}
$$

Все эти разновидности количественного индекса социальных инвестиций компании не являются нормируемыми и могут принимать любые положительные значения. Чем выше значение индекса, тем выше уровень социального инвестирования в компании.

2. Качественный индекс социальных инвестиций.

Качественный метод в отличие от количественного, создающего общую картину масштаба, оценивает степень комплексности и полноты социальной политики и КСО. Суть этого индекса заключается в учете фактического наличия или отсутствия в компании параметров, подлежащих оценке.

Индекс IK (i) показывает комплексность социальной политики и КСО и рассчитывается по следующей формуле:

$$
\boldsymbol{I} \boldsymbol{K}(\boldsymbol{i})=\left(1 / \mathrm{m} \sum_{(j=1)}^{m} X_{i j}\right) 100 \%,
$$

где $X i j$ принимает 1 , если $j$-й признак присутствует у $i$-й компании, и значение 0 , если этот признак отсутствует; $m$ - число индикаторов. 
Общий качественный индекс социальных инвестиций $I K$ показывает комплексность социальной деятельности в компании. Он выражается в процентах и формула его расчета выглядит следующим образом:

$$
\boldsymbol{I K}(\boldsymbol{i})=\left(\frac{1}{n m} \sum_{(i=1)}^{n} \sum_{j=1}^{m} X_{i j}\right) 100 \%
$$

Чем выше значение всех рассмотренных индексов, тем эффективнее социальная политика и КСО компании. Сравнение индексов для разных компаний позволяет выделять компании с развитой корпоративной социальной ответственностью, а также признаки, на которые руководству следует обратить внимание.

Среди элементов корпоративной социальной ответственности на всех этапах ее организации и реализации наиболее значимым является оценка эффективности КСО. Для повышения уровня эффективности региональных социальных программ необходимо создание и воспроизводство условий для устойчивого развития социальной среды территорий присутствия корпораций. Особое внимание также следует уделять работе по привлечению и удержанию квалифицированных работников. В этом плане значимым фактором выступает оптимальный баланс внутренних и внешних ресурсов.

Показателями эффективности проекта социального инвестирования являются: 1) показатели эффективности в целом; 2) показатели эффективности участия в реализуемом проекте государственных органов власти, корпораций и общественных организаций региона.

Предлагаемая система показателей эффективности инвестиционного проекта включает в себя следующие элементы [7].

I. Эффективность инвестиционного проекта в целом:

1. Социальная эффективность.

2. Интегральная эффективность проекта.

3. Коммерческая эффективность для проекта.

II. Эффективность участия в проекте:

1. Бюджетная эффективность.

2. Коммерческая эффективность.

3. Эффективность для населения территории присутствия корпорации.

4. Эффективность снижения текущих и единовременных затрат.

5. Эффективность выполнения подрядных работ и оказания услуг.

6. Эффективность снижения затрат.

7. Эффективность повышения доходов от реализации проекта.

8. Эффективность реального инвестирования.

9. Эффективность финансового инвестирования в проект.

10. Эффективность улучшения качества.

Оценка эффективности инвестиционного проекта производится посредством выявления потенциала привлекательности проекта для всех участников, а также путем поиска ресурсов. Этот вид эффективности рассчитывается при помощи трех показателей: социальной эффективности; интегральной эффективности; коммерческой эффективности в целом.

Эффективность проекта социального инвестирования определятся суммированием приведенного чистого дохода и затрат проекта. Как правило, в проектах регионального уровня принимают участие такие важнейшие субъекты, как государственная власть в лице различных органов, местное население и корпорации, поэтому показатели эффективности участия представляются следующим образом:

$$
\begin{aligned}
& \text { ЧДД }{ }_{j}^{\sigma}=\sum_{t=0}^{T} \text { ИД }_{j t}^{\sigma} \cdot a_{t}^{\sigma}=\sum_{t=0}^{T}\left(P_{j t}^{\sigma}-3_{j t}^{\sigma}\right) \cdot a_{t}^{\text {б }} \\
& \text { чДД }{ }_{j}{ }^{\mathrm{H}}=\sum_{t=0}^{T} \text { ИД }{ }_{j t}^{\mathrm{H}} \cdot a_{t}^{\mathrm{H}}=\sum_{t=0}^{T}\left(P_{j t}^{\mathrm{H}}-3_{j t}^{\mathrm{H}}\right) \cdot a_{t}^{\mathrm{H}} \text {, } \\
& \text { чДД }{ }_{j}{ }^{\kappa}=\sum_{t=0}^{T} \text { ЧД }_{j t}{ }^{\mathrm{K}} \cdot a_{t}^{\mathrm{K}}=\sum_{t=0}^{T}\left(P_{j t}^{\mathrm{K}}-3_{j t}^{\mathrm{K}}\right) \cdot a_{t}^{\mathrm{K}}
\end{aligned}
$$




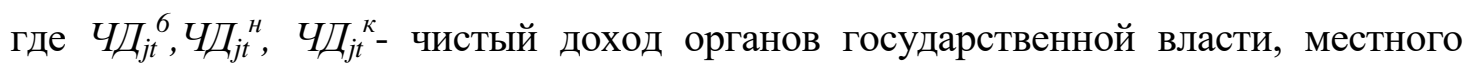
населения, корпораций по $j$-му проекту на $t$-м шаге, руб.;

$P_{j t}{ }^{\sigma}, P_{j t}{ }^{H}, P_{j t}{ }^{\kappa}-$ результат для органов власти, населения, корпораций по $j$-му проекту на $t$-м шаге, руб.;

$3_{j t}{ }^{\sigma}, 3_{j t}{ }^{H}, 3_{j t}{ }^{\kappa}-$ инвестиционные и текущие эксплуатационные затраты органов власти, населения, корпораций по $j$-му проекту на $t$-м шаге, руб.;

$a_{t}^{\sigma}, a_{t}^{H}, a_{t}^{\kappa}-$ коэффициент дисконтирования для органов государственной власти, местного населения, корпораций на $t$-м шаге;

$J=1,2, \ldots ., J$; где $J$ - совокупность проектов;

$T$ - расчетный период лет [4].

Для оценки методом дисконтирования необходимо определить коэффициент дисконтирования - $a_{t}$ и, требуемые нормы дисконта.

Для определения норм дисконта пригодны три метода: 1) по альтернативным вариантам инвестирования; 2) кумулятивный; 3) нормативный. Коммерческая, социальная, бюджетная норма дисконта, а также норма дисконта участника проекта зависят от рассчитываемого вида эффективности проекта.

Для расчета показателей общественной эффективности используется социальная норма дисконта. В этом случае общественная эффективность характеризуется минимальным требованием к социальной эффективности проектов частногосударственного партнерства (ЧГП) [1].

До установления социальной нормы дисконта, используется коммерческая норма, применяемая для оценки эффективности в целом. Мы считаем, что коммерческая норма дисконта должна приниматься по ставке Центробанка Российской Федерации.

Применение коммерческой нормы дисконта целесообразно в процессе оценки коммерческой эффективности инвестиционного проекта. Определение коммерческой эффективности осуществляется с учетом альтернативной эффективности, связанной с другими проектами, а также эффективностью использования капитала.

Бюджетная норма дисконта используется при определении расчета показателей бюджетной эффективности. С помощью бюджетной нормы хорошо отражается альтернативная стоимость бюджетных средств. Установка бюджетной нормы дисконта прерогатива органов власти регионов. С ее помощью власти оценивают бюджетную эффективность проектов. На практике вариантом бюджетной нормы дисконта выступает процент доходности государственных ценных бумаг.

Эффективность участия корпораций в проектах отражается через норму дисконта. Для корпораций чаще всего применяется коммерческая норма дисконта. Для местного населения при определении эффективности проекта используется минимальная норма дисконта, равная банковскому проценту по долгосрочным вкладам для физических лиц.

Ключевым показателем эффективности проекта является индекс доходности инвестиций, отвечающий следующим требованиям для каждого инвестора:

$$
\text { ИД }{ }_{j}^{n}=\frac{\sum_{t=0}^{T_{n}} \text { ч } д_{j t}^{n} \cdot a_{t}^{n}}{\sum_{t=0}^{T_{n}} K_{j t}^{n} \cdot a_{t}^{n}}+1 \geq 1 \text { для всех } j \epsilon J, n \in N,
$$

где $\quad 4 Д_{j t}{ }^{n}-$ чистый доход $n$-го на $t$-м шаге, руб.;

$K_{j t}{ }^{n}$ - инвестиционные затраты на $t$-м шаге, руб.;

$a_{n t}$ - коэффициент дисконтирования на $t$-м шаге;

$n=1,2, \ldots, N$; где $N$ - количество участников проекта [5].

Часто бывает, что не всегда органы государственной власти согласны с данным условием, поскольку не все проекты социального инвестирования преследуют коммерческие цели.

Еще одной проблемой при выборе проекта является учет финансовых ресурсов для нескольких участников проекта. Иногда бывает ситуация, когда проект является 
полезным и эффективным для местного населения и корпораций, однако выступает дополнительно затратным для органов государственной власти.

В процессе выбора инвестиционного проекта следует производить расчет показателей интегральной эффективности - ИД ${ }^{u t m} u$ ЧдД ${ }^{u t m}$, а также расчет показателя коммерческой эффективности - ЧДД ${ }^{n p}$.

Интегральный индекс доходности рассчитывается по следующей формуле:

$$
И Д_{j}^{u н т}=\frac{\sum_{n=1}^{N} \sum_{t=0}^{T} \text { Ч }_{j n t} \cdot a_{n t}}{\sum_{n=1}^{N} \sum_{t=0}^{T} K_{j n t} \cdot a_{n t}}+1,
$$

где $\quad$ ЧД int $_{\text {- }}$ чистый доход на $t$-м шаге, руб.;

$K_{\text {int }}$ - инвестиционные затраты на $t$-м шаге, руб;

$a_{n t}$ - коэффициент дисконтирования на $t$-м шаге.

Формула расчета интегрального чистого дисконтированного дохода выглядит так:

$$
\text { ЧД } Д_{j}^{i n t}=\sum_{n=1}^{N} \sum_{t=0}^{T} \text { Ч }_{j n t} \cdot a_{n t},
$$

Показатель интегральной эффективности - ЧДДит можно рассчитать, сопоставляя результаты и затраты участников социального инвестирования.

Эффективность проекта не вызывает сомнений, если сумма результатов превышает сумму затрат проекта.

По чистому дисконтированному доходу определяется абсолютный доход проекта, индекс доходности - это относительный доход, приходящийся на каждый рубль инвестиционных затрат.

Важно иметь в виду, что проект с максимальным значением ЧДД, не всегда имеет максимальный ИД среди рассматриваемых проектов. Это объясняется тем, что для реализации проектов необходим разный объем инвестиционных затрат.

При оценке эффективности корпоративного социального инвестирования приоритет отдается ЧДД, поскольку привлекать дополнительные инвестиционные ресурсы, и, соответственно, получать больший доход (ЧДД) выгоднее, нежели не заниматься привлечением имеющихся ресурсов, хотя и при большем значении ИД.

Определение показателя интегрального чистого дохода от проекта связано с приведением чистого дохода участников проекта к единому виду. С этой целью производится расчет чистого дохода коммерческих организаций по тем же правилам, как для органов государственной власти и местного населения, посредством определения разницы финансовых потоков "с проектом" и "без проекта". Расчет интегрального чистого дохода как чистого дохода корпораций производится по показателю прироста прибыли "с проектом" в сравнении с прибылью "без проекта".

При выборе наиболее эффективного проекта следует рассчитывать коммерческую эффективность для всех участников проекта. Формула расчета показателя коммерческой эффективности выглядит следующим образом:

$$
\text { ЧДД }{ }_{j}^{n p}=\sum_{n=1}^{N} \sum_{t=0}^{T} d_{n} \cdot \text { ЧД } j n t \cdot a_{n t},
$$

где $d_{n}$ - коэффициент значимости денежных показателей.

На основе анализа целей проекта и состава участников проводится корреляция финансовых потоков для различных субъектов с помощью поправочных коэффициентов $d_{n}$. Для выбора наиболее эффективного проекта необходим расчет показателя интегральной эффективности. Например, если принять $d_{n}=1$ для органов государственной власти, а для местного населения и корпораций $d_{n}=0$, то выбор наиболее эффективного проекта возможен с помощью показателя бюджетной эффективности.

Варианты выбора наиболее эффективного инвестиционного проекта определяются составом инициаторов и участников проекта:

Вариант 1. Инициатор проекта - местное население территории присутствия корпорации. Выбранный проект будет считаться эффективным, если он эффективен для 
его инициатора: $d_{n}=1$ для местного населения, $d_{n}=0$ для органов государственной власти и корпораций.

Вариант 2. Проект инициирован внешними для региона инвесторами. Главный показатель в этом случае - эффективность проекта для корпорации. То есть $d_{n}=1$ для инвестора, $d_{n}=0$ для остальных участников, но при этом неукоснительно должны соблюдаться интересы властных органов и местного населения.

Вариант 3. Органы государственной власти выступают инициатором проекта. Эффективный проект выбирается на основе показателя бюджетной или интегральной эффективности. В данном случае показатель $d_{n}=1$ для органов государственной власти, значение $d_{n}$ для местного населения и корпораций варьируется в диапазоне от 0 до 1 в зависимости от уровня социально-экономической значимости проекта для органов государственной власти.

Вариант 4. Выбор и реализация проекта осуществляется несколькими участниками. Если главный инициатор проекта - органы государственной власти, тогда механизм согласования проекта участниками проекта будет следующим. Для местного населения и корпораций устанавливаются минимальные значения эффективности проекта, затем определяется бюджетная эффективность, на основании которой выбирается самый эффективный проект. Для выбора проекта применяется показатель интегральной эффективности. Здесь показатель $d_{n}$ для участников проекта принимается равным их доле инвестиций.

Чтобы оценить степень реализуемости социального инвестиционного проекта необходимо определить показатель эффективности для местного населения и корпораций, а затем рассчитать бюджетную эффективность. Расчет показателя эффективности в целом выполняется в том случае, если соблюдаются следующие требования: экономические интересы местного населения не ущемляются (ЧДД $\left.{ }^{H} \geq 0\right)$ и обеспечены экономические интересы корпораций (ЧДД $\geq 0$ ).

Тогда алгоритм действий включает в себя следующие этапы:

Первый этап. Проведение мероприятий по разработке, экспертизе социального проекта, определению сроков и стоимости проведения работ.

Второй этап. Выявление инициатора проекта, определение состава заинтересованных участников и согласование организационно-правовых вопросов реализации проекта.

Третий этап. Определение горизонта расчета, разработка схемы финансирования и проведение оценки финансовых ресурсов для участников проекта.

Четвертый этап. Проведение расчета показателей финансовой эффективности проекта.

Пятый этап. Проведение корректировки финансовых ресурсов при уменьшении инвестиционных и текущих затрат или увеличении результата для населения территории присутствия. Таким образом, формируется схема финансирования проекта, которая приемлема для местного населения.

Шестой этап. Проведение корректировки финансовых ресурсов с помощью уменьшения инвестиционных и текущих затрат или увеличения эффекта для корпораций. Рассматривается и оценивается возможность софинансирования с помощью бюджетных источников или средств местного населения региона.

Седьмой этап. Проведение расчета бюджетной, интегральной эффективности, определение эффективности для инициатора проекта.

Восьмой этап. Принятие окончательного решения о реализации проекта.

Практика показывает, что на реализацию процесса социального инвестирования в регионах оказывают значительное влияние уровень имеющихся инвестиционных ресурсов, а также направления их использования. В настоящее время в российских компаниях наиболее популярным направлением в процессе оценивания является оценка результатов и эффектов социальных программ и проектов. 
Вместе с тем, российские компании часто игнорируют оценку разделяемой ценности, подтверждая лишь сам факт выполнения программы и проекта в обозначенных временных рамках и объемах. В отношении КСО компании декларируют стратегический подход и наличие планируемых социальных и бизнес-эффектов, но большинство конкретизировать используемую методологию не могут. Компании после принятия решения о направлении инвестиционных ресурсов, как правило, не контролируют и не корректируют процесс реализации социальных проектов, а при оценке не дифференцируют понятия результатов и эффектов.

Анализ и изучение практик управления социальной политикой и КСО российских корпораций позволяют выдвинуть ряд рекомендаций.

Во-первых, следует более четко увязывать выбор направлений корпоративных социальных инвестиций с основной деятельностью и корпоративной стратегией. Формулировка и реализация стратегии КСО должны базироваться на определении и ранжировании заинтересованных сторон, идентификации их ожиданий и потенциального вклада в разделяемую ценность, анализе связанных с их ожиданиями рисков, а также определении ожиданий компании в отношении создания разделяемой ценности. Наличие связи КСО с основной деятельностью и корпоративной стратегией обусловливает возможность получения бизнес-эффектов и повышает устойчивость реализуемых программ и проектов к экономическим кризисам.

Во-вторых, определение круга заинтересованных сторон, планирование направлений социальных инвестиций, постановка целей и формулирование основных групп показателей должны происходить на уровне высшего менеджмента (и желательно с участием акционеров). Организация работы и ответственность за реализацию КСО и оценку ее эффектов должна быть возложена на сотрудника или департамент в качестве их основных должностных обязанностей. При ограниченности ресурсов данные обязанности возлагаются на какой-либо функциональный отдел. В этих условиях необходимо минимизировать риски концентрации на отдельных группах заинтересованных сторон в ущерб остальным. Следует также избегать чрезмерной "маркетинговой" ориентации КСО, которая из стратегического инструмента генерации разделяемой ценности превращается в деятельность по поиску и обнародованию случайных и намеренных эффектов, наиболее выгодных в глазах внешних наблюдателей.

В-третьих, при организации и проведении оценки КСО рекомендуется разделять результаты КСО, подразумевающие продукт или услугу, получаемые в итоге потребляющей ресурсы деятельности, и эффекты КСО, представляющие собой воздействие полученного результата на благосостояние заинтересованных сторон. Результаты и эффекты КСО должны планироваться на этапе определения направлений социального инвестирования. Также следует использовать максимально конкретные показатели, затрагивающие возможные положительные и отрицательные эффекты. В бюджет компании следует включать административные расходы, связанные с оценкой КСО и привлечением внешних экспертов.

В-четвертых, при оценке эффектов КСО, как показывает анализ российской практики, следует выделять четыре направления: 1) оценку социально-ответственного поведения сотрудников отделов по цепочке создания ценности; 2) оценку изменений в бизнес-процессах, направленных на поддержание принципов КСО; 3) оценку социальноответственных программ и проектов; 4) оценку корпоративной благотворительной деятельности. При этом российским компаниям стоит обратить внимание на редко затрагиваемую ими область оценки социально ответственного поведения отделов и сотрудников по цепочке создания ценности, которая может проводиться только при наличии единых этических стандартов.

В-пятых, российским компаниям необходимо более внимательно относиться к роли обратной связи в оценке эффектов КСО. Недостаточное представление эффектов КСО, в противовес ее результатам, обусловлено слабой вовлеченностью внешних 
заинтересованных сторон в процесс оценки. Выступая качестве стороннего наблюдателя, компания не может объективно оценить влияние собственной деятельности на благосостояние заинтересованных сторон. На сегодняшний день в российских компаниях относительно хорошо развиты системы сбора обратной связи от покупателей/клиентов, часто анкетируются сотрудники, но остальные группы заинтересованных сторон, как правило, опрашиваются бессистемно. Наиболее остро данная проблема стоит при оценке эффектов корпоративных социальных программ, где компании обрывочно собирают отдельно взятые отзывы и помещают их в нефинансовые отчеты как знак успеха. Рекомендуется заблаговременно планировать соответствующие процедуры сбора информации и административные расходы, что позволит своевременно агрегировать данные о восприятии и удовлетворенности заинтересованных сторон.

1. Варнавский, В.Г. Государственно-частное партнерство: теория и практика / В.Г. Варнавский, А.В. Клименко, В.А. Королев. - М.: ГУ ВШЭ, 2010. - 287 с.

2. Воеводкин, Н.Ю. Социальная ответственность в системе корпоративного управления / Н.Ю. Воеводкин // Ars Administration (Искусство управления). - 2011. - № 4. - C.45-55.

3. Жойдик, А.П. Методы оценки корпоративной социальной ответственности бизнеса / А.П. Жойдик // Российское предпринимательство. - 2013. - Том 14. - № 6. - С. 94-98.

4. Методические рекомендации по оценке эффективности инвестиционных проектов. - М.: ОАО Издво "Экономика", 2013. - 421 с.

5. Николаев, И.А. Доверие в экономике: количественная оценка. Аналитический доклад. - М.: Изд-во ФБК, 2006. - 38 с.

6. Симонова, Л.М., Аникеева, О.П., Бедрина, Л.А. Модели корпоративной социальной ответственности / Л.М. Симонова, О.П. Аникеева, Л.А. Бедрина // Всероссийский журнал научных публикаций. - 2013. - № 5. - С.30.

7. Теслюк, Л.М., Румянцева, Л.М. Оценка эффективности инвестиционного проекта / Л.М. Теслюк, Л.М. Румянцева. - Екатеринбург: УрФУ, 2014. - 141 с.

\section{Усанова К.Д., Мищенко Е.А. \\ Социально-экономическое устройство древнерусского государства}

Кубанский государственный аграрный университет имени И. Т. Трубилина

doi: $10.18411 /$ scienceconf-05-2019-49

idsp: scienceconf-05-2019-49

\section{Аннотация}

В статье рассмотрено становление и развитие феодализма в Древней Руси. Определены основные этапы перехода крестьян в зависимость к феодалам. Выявлено преобладание в древнерусском государстве земледелия, торговли, ремесла и металлургии над другими отраслями народного хозяйства. Рассмотрены особенности первого этапа российской урбанизации в следствии роста сел, проанализировано значение древнерусского города в аспекте эволюции торговых и административно-политических центров.

Ключевые слова: феодализм, княжеская дружина, система налогообложения, село, город, земельная собственность, классовое расслоение.

Социальная структура древнерусского общества имела элементы феодализма, первобытно-общинного строя, и даже рабовладения. В Киевской Руси существовало уже заметное расслоение общества. Система взаимоотношений населения включала в себя производство продукции, несение военной службы и сбор налогов. Налогообложение на Древней Руси началось с дани, которая называлась полюдье. Оно являлось выражением верховного права князя на землю и установления понятия подданства, собиралось со всего населения. Сбор полюдья происходил ежегодно, с ноября по апрель. Место, время и размер сбора дани заранее не определяли, причем старшие дружинники со своими 
отрядами могли собирать большее количество дани, чем князь. Что нередко вызывало протест у крестьян. В следствии этого в 945 году княгиней Ольгой была проведена налоговая реформа, установившая «уроки» - нормы дани, а также «погосты» - время и сроки ее сбора. Эта реформа - первая попытка упорядочения сбора дани в древнерусском государстве.

По мере того, как развивались производительные силы, у славянских племен начали различаться определенные группы населения, делящиеся между собой по социальному положению и благосостоянию. Так начала появляться знать, куда входили «лучшие мужи». В обществе самый высокий статус занимали «земские бояре» - это были выходцы из племенной аристократии, потомки родовых старейшин и торговцы, жившие на торговом пути «из варяг в греки». Верховные дружинники, «княжьи мужи», относились к высшим социальным слоям. В X - XI веках процесс феодализации в Киевской Руси усиливается, появилась заинтересованность в закреплении земли в постоянном владении. Частную собственность на землю стали называть вотчиной, эту землю можно было купить, продать или передать по наследству. С этого периода крестьяне, или смерды, начинают не только выплачивать дань государству, но и становятся зависимыми от боярина (феодала). Они обязуются выплачивать ему оброк или отрабатывать барщину за пользование землей. В этот период значительное число жителей еще оставалось независимыми от бояр.

Если говорить исключительно об основном источнике экономического развития, то натуральное хозяйство, торговля, ремесло и металлургия имели наибольшее значение. Земледелие - основная отрасль хозяйства в Киевской Руси, распространено на всей территории государства. Так как в этот период происходили развитие земледелия и прирост населения, возникала необходимость в освоении новых земель для пахоты. Так же славянские племена занимались животноводством - разводили волов, лошадей, крупный рогатый скот, птиц и др. Вспомогательную, но очень важную роль играли рыболовство, бортничество, охота.

Главенствующую роль занимала черная металлургия по той причине, что на территории Древней Руси находились болотные руды, из которых впоследствии добывалось железо. При обработке железа изготавливались многочисленные вещи для хозяйства, быта и военного дела. При этом применялись различные приемы: варка, ковка, обточка, цементирование, инкрустация цветными металлами. Металлургия и сельское хозяйство - прочная основа экономики в Древней Руси. И ее основная задача - решение вопросов, касающихся всего населения, таких как производство и сбыт продукции, порядок сбора налогов и прохождение военной службы.

Торговля в древнерусском государстве проходила в основном по водным путям, везли ткани, пряности, стеклянные и ювелирные изделия, книги, иконы, вина и многое другое. Вывозились же продукты натурального хозяйства, ремесленные изделия и рабы. Феодалы не редко продавали челядь в другие страны. Это было самое низшее сословие наряду с холопами. Они находились в рабской зависимости от господ. Челядь состояла изначально из военнопленных и их потомков, следовательно эта категория угнеталась в наивысшей степени. Понятие холоп появилось только с развитием феодальных отношений, когда многие соплеменники начали попадать в рабскую зависимость от своих господ. Они составляли категорию зависимого населения Киевской Руси практически полностью утратившую свободу и в случае несчастья рассчитывающую только на милость своих господ. [2, с 5]

Степень несвободы объяснялась экономическим положением крестьянина: смерды, рядовичи, закупы - землевладельцы, попавшие в частичную зависимость от феодалов по тем или иным причинам. Они обязаны были отрабатывать значительную часть времени на вотчинных землях. Зависимость рядовичей от господ была чисто феодального характера, так как рядович вступал в зависимое положение от землевладельца и нес в его пользу феодальный повинности через подписание особого 
договора (ряда). Главным отличием закупов от холопов является то, что они вели личное хозяйство и, со временем отдав долг, могли получить свободу.

Так как земля - основное средство извлечения богатства, то владение землей привилегия, в основном для людей, несущих военную или государственную службу. Что касается последнего, то главой древнерусского государства был правивший в Киеве великий князь. Власть князья могли передавать не только от отца к детям, но и от брата к брату, от дяди к племяннику и т. д. В то время не было развитого государственного аппарата и князь не являлся абсолютным монархом. На местах князем для представления власти назначались посадники или волостники. Со второй половины $\mathrm{X}$ века на крупных территория управляли удельные князья, которые нередко являлись сыновьями великого князя. Также при князе функционировал совет (дума), в который входили представители высшей аристократии и духовенства. Остальное же население принимало участие в собрании городских жителей - вече, в котором могли принять участие все взрослые мужчины города. Роль древнерусского войска играла дружина, которая была опорой княжеской власти и участвовала в управлении государством. Дружинников разделяли на старших - бояре, княжеские мужи, и младших - отроки. Старшая дружина принимала участие в военных походах, дипломатических сношениях с иностранными державами, также в ее обязанности входило управление княжеским домениальным хозяйством и государством в роли княжеских посадников и волостей. Младшая дружина являлась личной гвардией князя, которая обязывалась участвовать в военных походах и выполняла отдельный поручения по управлению его домениальным хозяйством и государством в качестве мечников и стражей общественного порядка. Помимо этого в военное время собиралась еще военное ополчение - «вои ».

Процесс феодализма характеризуется тем, что на начальном этапе становления феодальных отношений проявляется зависимость непосредственных производителей от государственной власти (это государственные, судебные и иные виды подати). И лишь постепенно на смену ей приходит складывание индивидуальной крупной земельной собственности (вотчинная).

Большая часть населенных пунктов в Древней Руси - это села, которые были некими центрами земледелия, животноводства и промысла. В них размещались дворы административные и хозяйственные центры владений феодалов. Немалую долю жителей сел составляли крестьяне - население, занятое в этих отраслях производства, а также феодалы, собственники той земли, на которой проживали и трудились крестьяне, называемые смердами. Они делились на две разные категории - лично свободные члены общины и феодально зависимые. В следствии такого деления также различают два вида сельских поселений - с замками и без них. Крестьяне, непосредственно живущие вблизи вотчины феодала, являлись зависимыми смердами. Население, проживающее в отдаленных от феодалов дворах, представляет собой лично свободных смердов, которые подчинялись князю непосредственно как главе государства. Благодаря отлаженным общинным механизмам удавалось успешно минимизировать индивидуальные социальные риски, последствия неурожаев и продовольственных кризисов [3, с. 43].

При формировании феодальных отношений в результате разделения труда, развития торговли и ремесла в обществе выделились определенные слои, социальные и экономические интересы, которых вынуждали купцов и ремесленников сгруппироваться в определенных местах. Так и появились первые города как центры социальноэкономической жизни. Торговцы снабжали сельское население ремесленной продукцией, которое в свою очередь обеспечивало ремесленников и торговцев натуральным продуктом. Эволюция городского ремесла в Древней Руси стимулировалась интенсивным развитием государственного хозяйства, торгового сектора и военно-оборонительных потребностей местного населения [4, с 14]. Города были центром политической, религиозной и культурной жизни. Немалая часть древнерусских городов возникала из поселений, которые в условиях развития феодальных отношений росли и образовывали 
торговые и административно - политические центры в определенной округе. Тесная экономическая связь города и деревни представляется важнейшей национальной особенностью народнохозяйственной структуры России [1, с 108].

С течением времени развитие крупной земельной собственности приводит к увеличению значимости светской власти, роль городов для древнерусского общества неумолимо возрастает, формируются первые упорядоченные системы налогообложения. Развитие производства объясняло ускорение классового расслоения древнерусского государства. Из этого следует, что в древнерусском обществе развиваются государственно - правовые и экономические отношения, и к середине XI века в Древней Руси окончательно формируется сословно - феодальный строй.

$$
* * *
$$

1. Шулимова А.А. Эволюция корпоративных форм организации экономики российского города // Региональная экономика. Юг России. - 2014. - № 2. - С. 106-114.

2. Шулимова А.А., Шулимова Е.А. Социальные механизмы в русском ремесленном производстве домонгольского периода (по исследовательским данным М.Н. Тихомирова) // Социальногуманитарный вестник: Всероссийский сборник научных трудов. - Краснодар: ЦНТИ, 2011. - С. 58.

3. Шулимова А.А. Эволюция институциональных форм социальных инвестиций в современной России// Современная экономика: проблемы и решения. - 2015. - №3(63). - С.40-46.

4. Шулимова А.А., Шулимова Е.А. Экономическая история российских ремесленных корпораций // Кубанские исторические чтения: материалы V Международной научно-практической конференции. - Краснодар: ЦНТИ, 2014. - С. 13-17.

\section{Хачемизов А.P. \\ Бережливое производство как инструментарная подсистема контроллинга на предприятии}

AO "Краснодарпроектстрой" (Россия, Краснодар)

doi: $10.18411 /$ scienceconf-05-2019-50

idsp: scienceconf-05-2019-50

\section{Аннотация}

Цель публикации данной статьи состоит в определении роли и места бережливого производства в системе контроллинга на предприятии. При этом рассматриваются задачи идентификации функционала контроллинга и бережливого производства. В результате решения задачи определено содержание функций контроллинга и бережливого производства, выполнена классификация задач управления, решаемых с помощью инструментов бережливого производства в рамках контроллинга. решений.

Ключевые слова: контроллинг, бережливое производство, функции, принятие

В современных условиях экономической нестабильности особую актуальность приобретает концепция управления предприятием «бережливое производство». Такой подход позволяет предприятиям стабильно развивать производство и рыночную деятельность в условиях дефицита ресурсов и изменения требований рынка. Это обусловливает необходимость повышения эффективности предприятия путем оптимизации всех производственных и рыночных процессов. Это достигается через преобразование системы затрат рационального использования имеющихся ресурсов, обеспечение высокого уровня качества продукции, выпускаемой предприятием.

В основе высокой эффективности предприятия лежит системный подход к управлению всеми его процессами, а также, минимизация потерь, основанная на принципах бережливого производства. В тоже же время концепция бережливого производства с наибольшей полнотой моет быть реализована в рамках системы 
контроллинга [1]. Тоесть имеет место вложенная конструкция - системный подход контроллинг - бережливое производство. При этом под контроллингом понимается комплексная подсистема поддержки управления предприятием, направленная на координацию взаимодействия всех систем менеджмента и контроля их эффективности [2]. По существу, если контроллинг является подсистемой управления то «бережливое производство» является одним из инструментов его реализации.

В свою очередь бережливое производство представляет собой систему взаимосвязанных и взаимозависимых подсистем управления предприятием, ориентированных на потребителя. Данная система предполагает вовлечение в процесс ее реализации всех сотрудников, путем мощной системы мотивации. Управление предприятием подразумевает реализацию множества функций таких как: планирование, организация, учет, анализ и регулирование, координация [3]. Данные функции в обязательном порядке реализуются при любом концептуальном подходе к формированию системы управления предприятием.

Функция планирование определяет направления развития предприятия на перспективу. Планирование позволяет четко определить направления деятельности структурных подразделений, стимулирует понимание коллективной ответственности. В условиях рыночной экономики самостоятельное формирование и реализация экономических планов предприятия с учетом собственных возможностей, специфики и ресурсов является важнейшей экономической задачей и лежит в основе его производственного потенциала. Вся система планирования на предприятии базируется на ее важнейшем компоненте - маркетинговых исследованиях. Данная основа позволяет продвигать продукцию на рынок и повышать ее конкурентоспособность.

Следующей важнейшей функцией системы управления предприятием является функция организации, что позволяется систематизировать и оптимизировать все виды деятельности, что позволит достичь высокой эффективности. В основу организации функционирования предприятия положен мониторинг многообразия процессов, реализуемых на предприятии, что позволяет системно решать всевозможные задачи и своевременно выявлять проблематику.

Функция учета обеспечивает контроль за выполнением всех планов на предприятии на основе сбора систематизированных данных для детального и всестороннего анализа. Результаты анализа позволяют сделать процесс принятия решений на предприятии более эффективным. Анализ позволяет полноценно оценить работу предприятия и выявить недочеты и сбои в работе предприятия, определить наиболее привлекательные направления для использования ресурсов и т.п.

На основе анализа реализуется функция регулирования, предусматривающая корректировку планов, выявление потенциальных угроз и нахождение эффективных способов их устранения. Функция регулирования позволяет скоординировать работу предприятия самым оптимальным для него образом.

Bce перечисленные функции реализуются в рамках действия системы контроллинга, охватывающей все основные и вспомогательные подразделения предприятия. Предполагается, что эффективность компонентов и элементов контроллинга непрерывно повышается посредством использования принципов и инструментов бережливого производства. Основная цель бережливого производства состоит в непрерывном повышении качества и эффективности действия всех подсистем предприятия. Для реализации этой цели необходимо обеспечить достижение текущих и стратегических целей предприятия на основе функционирования действенной системы контроллинга, обеспечивающего анализ данных, контроль и обоснование решений по реализации указанных целей.

На сегодняшний день основой системы принятия управленческих решений на предприятии является плановая аналитическая работа. В этой связи контроллинг обеспечивает эффективность принятия управленческих решений. Посредством 
контроллинга осуществляется системный анализ возможностей и угроз, определяются перспективные направления развития, позволяющие рационально использовать резервы [4].

Важнейшая функция контроллинга состоит в оценке перспективности принимаемых решений. В связи с разнообразием задач, решаемых на предприятии, предлагается рассматривать эту функцию а двух этапах принятия решений: предварительном и окончательном. На первом этапе осуществляется предварительная оценка вариантов решений на основе анализа информационного массива показателей функционирования предприятия, сформированного в системе контроллинга. На окончательном этапе оценки решений выявляются особенности реализации решений и оцениваются варианты их реализации [5]. Таким образом, оценка перспективности определяет рациональность или иррациональность принятого решения и позволяет выбрать наиболее приемлемый путь развития и устранения возможных проблем.

Основной целью бережливого производства является непрерывное совершенствование с применением постоянных улучшений, направленное на минимизацию потерь. Все задачи, решаемые в рамках бережливого производства условно можно разделить на четыре блока. Данная классификация представлена на рисунке.

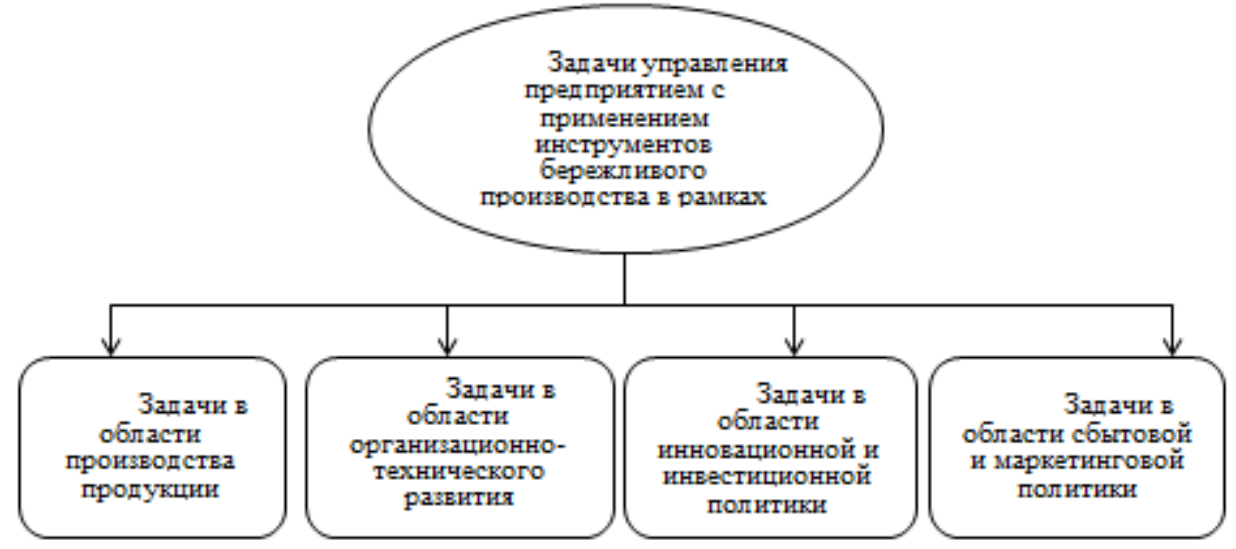

Рисунок - Классификачия задач бережливого производства, реализуемых посредством инструмента контроллинга

В контексте производства продукции решается ряд задач, связанных с модификацией и расширением ее ассортимента, вносятся изменения в структуру производственной программы, внедряются мероприятия по снижению себестоимости.

В области сбытовой и маркетинговой политики решаются задачи создания по организации сотрудничества с поставщиками и потребителями, определяются рынки сбыта продукции, формирования сервисных центров, оптимизации ценовой политики, разработки программ развития предприятия.

В рамках инновационной и инвестиционной политики реализуются задачи по освоению новых технологий, внедрения инноваций, производится поиск инвесторов, модернизации информационной системы предприятия.

Организационно - техническое развитие подразумевает совершенствование организационной структуры, оптимизацию кадровой политики, реконструкцию технического оборудования, рациональное использование производственных площадей, проведение мероприятий, направленных на улучшение условий труда и прочее [6].

Таким образом, основываясь на проведенных исследования, предлагаются следующие выводы:

- «бережливое производство» является инструментарной основой реализации управленческой концепции контроллинга;

- под контроллингом понимается комплексная подсистема поддержки управления предприятием, направленная на координацию взаимодействия всех систем менеджмента и контроля их эффективности; 
- основной целью бережливого производства является непрерывное совершенствование с применением постоянных улучшений, направленное на минимизацию потерь.

Экономический эффект от мероприятий, внедряемых в рамках бережливого производства, определяется размером прибыли от его реализации. Рациональность реализованных мероприятий по бережливому производству определяется на основе анализа соотношения выручки и затрат.

$$
* * *
$$

1. Данилочкина Н.Г, Чернер Н.В, Боброва М.Б. Контроллинг как инструмент бережливого производства // Контроллинг, как механизм реализации проектов интегрированной системы менеджмента и бережливого производства. Сборник научных трудов V научно-практической конференции по контроллингу. Москва, 2016 г.

2. Путятина Л.М., Джамай Е.В., Тарасова Т.В.. Структура и содержание управленческого анализа на предприятии в современных условиях // Вестник МГОУ. Серия: Экономика. 2014. №4. С. 136-139.

3. Данилочкина Н.Г. Бережливое производство как результат контроллинга // Экономика и Жизнь №45, 2009.

4. Майер Э. Контроллинг как система мышления и управления. - М.: Финансы и статистика, 1993.

5. Хачемизов А.Р. Формирование контроллинга в системе управления промышленной организации // Материалы XXXV Недели науки МГТУ: XXX Всероссийская научно-практическая конференция «Образование - наука- технологии» - Майкоп: Изд-во «ИП Кучеренко В.О.», 2017. - 218 с.

6. Дайле А. Практика контроллинга. М.: Финансы и статистика, 2001.

\section{Шаланина Н.А., Гординский Д.В. \\ Унификация правил таможенного контроля в условиях цифровизации таможенного администрирования: зарубежный опыт}

ГКОУ ВО «Российская таможенная академия»

Владивостокский филиал

(Россия, Владивосток)

doi: 10.18411/scienceconf-05-2019-51

idsp: scienceconf-05-2019-51

\section{Аннотация}

В статье рассмотрен зарубежный опыт таможенного контроля в условиях цифровизации таможенного администрирования. Предложенный в статье подход позволяет максимально содействовать развитию внешнеторговой деятельности компаний без ущерба для результативности таможенного контроля и обеспечения национальной экономической безопасности.

Ключевые слова таможенный контроль, система управления рисками, унификация правил таможенного контроля

\section{Abstract}

The article describes the foreign experience of customs control in the conditions of digitalization of customs administration. The approach proposed in the article allows to maximally promote the development of foreign trade activities of companies without compromising the effectiveness of customs control and ensuring national economic security.

Key words customs control, risk management, unification of customs regulations

Принципы цифровизации таможенного администрирования, изложенные в Международной конвенции по упрощению таможенных процедур от 18.05.1973 года и Рамочных стандартах по безопасности и упрощению мировой торговли 2006 года, устанавливают приоритет информационных таможенных технологий и сводят применение форм таможенного контроля к необходимому минимуму для обеспечения соблюдения таможенного законодательства. Стандарт 6.3 Конвенции предписывает 
использование системы управления рисками при проведении таможенного контроля. Основной проблемой на данный момент является недостаточная эффективность таможенного контроля, заключающаяся в излишнем требовании предоставления бумажных документов, неразвитой инфраструктур и слабой оснащенностью российских таможенных органов в пунктах пропуска.

Одной из ключевых идей, призванных как повысить эффективность таможенного контроля, так и снизить нагрузку на участников внешнеэкономической деятельности является система управления рисками (далее - СУР).

Таможенный контроль является одним из инструментов проведения таможенной политики государства и построен на принципе выборочности форм, мер таможенного контроля с использованием СУР. СУР - динамически развивающаяся система, позволяющая в короткие сроки, с минимальными затратами принять решение о выпуске товаров.

В условиях цифровизации таможенного администрирования актуальность снижения применения форм и мер таможенного контроля является первоочередной задачей. $\mathrm{C}$ нашей точки зрения, представляется целесообразным обратиться к международному опыту и передовым практикам таможенного регулирования. В частности, интерес представляет опыт внедрения системы управления рисками, как неотъемлемой части таможенного контроля, в Европейском союзе.

Первым нормативным документом, регламентирующим применение СУР в Европейском Союзе, стала «Стандартная структура по управлению рисками в таможенных администрациях EC» (TAXUD/629/2000-EN), принятый в 2002 году в Брюсселе. В данном руководстве, созданном на основе программ «Таможня-2002 Согласованная модель управления риском» и «Структура управления риском», рассматривались общие подходы к управлению рисками, практические основы для их организации и место и роль таможенных органов в данной системе.

Принципы функционирования СУР в правовую базу Европейского союза были внесены в 2005 году, а в период с 2009 по 2011 гг. система внедрялась в практическую деятельность. В настоящее время правовая база СУР ЕС основана на положениях Таможенного кодекса ЕС, вступившего в силу 1 мая 2016 года.

Ключевые цели по применению СУР изложены в Стратегии ЕС по управлению рисками (Communication on the EU Strategy and Action Plan for customs risk management: Tackling risks, strengthening supply chain security and facilitating trade).

Стратегия ЕС по управлению рисками предписывает создание нормативноправовой базы для обеспечения таможенных органов информацией об основных направлениях ввоза товаров на таможенную территорию ЕС. Особое внимание уделено поддержанию доступности этой информации и наличию квалифицированного персонала таможенных органов и иных контролирующих служб. Для получения информации о рисковых поставках Еврокомиссия использует несколько источников. К ним относятся:

- информация, полученная из открытых источников;

- информация, полученная из отдела управления рисками Генерального директората по налогообложению и таможенному союзу;

- информация, полученная из иных служб Еврокомиссии, сотрудничающих Генеральным директоратом и от государств-членов.

В Стратегии определены следующие ключевые цели:

1. Улучшение качества данных и порядка подачи заявок;

2. Обеспечение доступности данных о направлениях поставок и обмен информацией о рисках между таможенными органами;

3. Осуществление мер контроля и снижения риска, где это необходимо;

4. Укрепление потенциала системы; 
5. Содействие межведомственному сотрудничеству и обмену информацией между таможенными и другими органами на уровне государств-членов и $\mathrm{EC}$;

6. Расширение сотрудничества с торговлей;

7. Раскрытие потенциала международного таможенного сотрудничества.

Помимо необходимости в согласовании технических требований, предъявляемых к данным, используемым системой управления рисками, Еврокомиссии необходимо определить основные проблемы, возникшие в правоприменительной практике Таможенного кодекса ЕС. С момента вступления Кодекса в силу, Еврокомиссия на постоянной основе проводит консультативные встречи с государствами-членами и деловыми кругами для выявления и решения проблем законодательства и технических вопросов. Основной темой данных встреч является создание новой информационной системы перемещения грузов и требования к новой декларации на ввозимые товары.

На данный момент для ввозимых товаров используется итоговая ввозная декларация (Entry Summary Declaration), проведен сбор данных, необходимых для улучшения декларации. Это стало возможным благодаря учету различных бизнесмоделей, результатов экспериментальных действий по обеспечению безопасности грузоперевозок и оценки эффективности Системы контроля импорта-1.

Помимо этого, предложено унифицированное решение сбора и интеграции данных итоговой ввозной декларации из торговых источников, которое основано на анализе стоимости и выгод и связанных с этим вопросов использования (включая технические, финансовые и организационные вопросы).

Несмотря на принятие всех нормативно-правовых актов, регулирующих применение Системы Контроля Импорта 2 (Import Control System 2), которая должна сменить Систему контроля импорта-1, создание второй версии системы в настоящий момент не начато, что не позволяет достигнуть целей и желаемых результатов. Система контроля импорта-2 будет реализована в 3 шага:

- с 15 марта 2021 года новые требования итоговой ввозной декларации будут применяться для товаров, перемещаемых в экспресс и международных почтовых отправлениях, перемещаемых воздушным транспортом;

- с 1 марта 2023 года новые требования будут применяться для всех товаров, перемещаемых воздушным транспортом;

- с 1 марта 2024 года новые требования будут применяться для товаров, перемещаемых морским, железнодорожным и автомобильным транспортом.

Особое внимание уделено созданию системы электронного документооборота на всей территории ЕС. Еврокомиссия совместно с государствами-членами и торговым сообществом разрабатывает информационные системы, которые смогут реализовать положения Таможенного кодекса ЕС. Тем не менее, несмотря на то, что программа «Таможня-2020» предусматривает разработку и внедрение информационных систем к 2020 году, Европейская комиссия приняла поправку к статье 278 Таможенного Кодекса ЕС, продлевающую срок переходного периода до 2025 года.

Таким образом, предполагается, что полный комплект информационных систем позволит осуществить модернизацию и гармонизацию импортных, экспортных и транзитных операций и станет основой для внедрения концепции централизованного оформления и выпуска товаров.

$$
* * *
$$

1. "Международная конвенция об упрощении и гармонизации таможенных процедур" (совершено в Киото 18.05.1973) (в ред. Протокола от 26.06.1999)

2. Таможенный кодекс Евразийского экономического союза. - Москва: Проспект, 2017. - 512 с. 
3. Second Progress Report on the implementation of the EU Strategy and Action Plan for Customs Risk Management (Brussels, 20.7.2018 COM(2018) 549 final Режим доступа: https://ec.europa.eu/taxation_customs/sites/taxation/files/crm_second_progress_report.pdf

4. Proposal for a Regulation of the European Parliament and of the Council amending Regulation (EU) No 952/2013 to prolong the transitional use of means other than the electronic data-processing techniques provided for in the Union Customs Code (Brussels, 2.3.2018 COM(2018) 85 final) Режим доступа: https://eur-lex.europa.eu/legal-content/EN/TXT/PDF/?uri=CELEX:52018PC0085\&from=HR

5. Объ утверждении планат мероприятий («дорожнойт карты») «Совершенствование

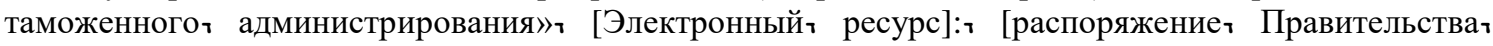
РФ:ヶ от 29.06.2012 http://www.consultant.ru⿰ (датат обращения: > 20.09.2018 т г)

6. Круглыйт стол.т Актуальные т вопросыт таможеннойт практики.т Системат управления рискамит в таможенном деле.т Категорированиел участниковт ВЭД.т Системат контроля таможенной стоимости [Электронный http://dvtu.customs.ru/index.php?option=com

\section{Chernyh V.V., Nizova L.M., Suvorova A.P. Administrative barriers as a phenomenon of regulation of the market environment at the meso-economic level}

Volga State Technological University (Russia, Yoshkar-Ola)

doi: 10.18411/scienceconf-05-2019-52

idsp: scienceconf-05-2019-52

\section{Abstract}

The market environment at the meso-economic level and the limiting factors in the form of administrative barriers, which have a positive or negative effect, are investigated. Causal relationships between administrative barriers and the market environment are established, the infrastructure of which includes a system of formal and informal institutions. Based on the comparison of opinions of scientists, the contradictions of theories about administrative barriers are revealed, their economic and institutional nature is revealed, the effect of which depends on thinfrastructure and the state of the market environment. Classification and forms of regulation of administrative barriers have been carried out. The financial result of the unprofitable organizations of the Republic of Mari $\mathrm{El}$ in the context of urban districts and municipal districts, wage arrears and the level of wage differentiation in various branches of the informal economy at the meso-economic level has been monitored. Improving the quality of life depends on the structure of employment, the balance of demand and supply of labor, the effectiveness of jobs with decent pay. All this allowed us to solve the set goal and tasks to study the impact of administrative barriers on the market environment and develop an algorithm for their mutual influence, taking into account negative and positive externalities. At the same time, the latter causes: profit growth, the emergence of new enterprises, improvement of working conditions between business entities, which contributes to the increase of budgetary allocations and the maintenance of stability by the state in the institutional environment. On the other hand, the impact of administrative barriers has a negative effect: a decrease in profits, the closure of enterprises, a deterioration in the business environment. The result is a reduction in allocations to the budget, an increase in wage arrears, which causes market failures and the need to adjust or neutralize barriers. The authors concluded that barrier regulation in the market environment should be aimed at achieving positive effects and minimizing negative consequences.

Key words: administrative barrier, market, market environment, negative effect, positive effect, meso-economic level, wages, informal employment.

\section{Introduction}

In the current market environment of the most diverse spheres of economic activity, one can note the presence of limiting factors. Such restrictions act as distinctive "barriers" present in 
various forms and at virtually all stages of production and decision-making. They are called, as is known, "administrative barriers", which have both a positive and a negative effect.

In the opinion of the President of the Russian Federation: "... for the economy to work in full force, we need to radically improve the business climate, ensure the highest level of entrepreneurial freedoms and competition".

The purpose of this study is to examine the impact of administrative barriers on the market environment, as well as the external effects arising from such an impact.

In the process of research the following tasks are solved:

- Comparison of the interpretations of the "administrative barrier";

- development of the main components of the infrastructure of the market environment, taking into account formal and informal institutions;

- Assessment of classification groups of administrative barriers;

- generalization of the mechanism of barrier regulation;

- development of a scheme of the impact of barriers on the market environment, taking into account negative and positive externalities;

- establishing a link between the well-being of citizens, balancing the supply and demand of the workforce, the efficiency of workplaces with the aim of updating the structure of employment, reducing informal employment and differentiating in wages.

The notion of an "administrative barrier" appeared in the works of modern scientists relatively recently. A detailed study has revealed a number of new approaches to the consideration of this conceptual apparatus.

The basis for the formation of administrative barriers was laid in the perestroika period during the transformation of the market system and the development of a legislative framework in the field of entrepreneurship. When analyzing this concept, it is necessary to take into account the general hierarchy of legislative acts, such as the Constitution of the Russian Federation, Civil, Criminal, Tax, Housing and Labor Codes.

The object of special attention should be an assessment of legislative initiatives and federal regulations, which are sometimes divorced from life's realities. As a tool, the most frequently used influence on entrepreneurial activity through administrative barriers, tax and economic policies are generally considered, although restrictions exist in other legislative acts.

\section{Theory and Experimental}

Scientists consider administrative barriers through the prism of the institutional environment: D.S. Nord] writes about the existence of "informal restrictions" in the institutional environment, and B.Z. Milner] emphasizes the existence of restrictions developed by lawmakers. A.N. Oleinik carries out a comparative analysis of the norms of formal and informal institutions, among which there are limitations of a barrier nature.

A detailed analysis of administrative barriers is presented in the work of E. De Soto. Considered barriers such as the costs of business registration, obtaining licenses, the costs of continuing activities under the law, for example, paying taxes, providing mandatory reporting. This question is studied in more detail in the works of A.A. Auzan and P.V. Kryuchkova. They defined the concept of "administrative barriers", as well as classifying groups of administrative barriers.

In the work of E.V. Porazanova the main reasons for the emergence of contradictions in the market environment are outlined. So, the reasons for the emergence of external (exogenous) barriers within local markets are that the local market is both an independent system and a part of the domestic market of the country. Administrative barriers are considered in I.V. Petrov's monograph. The author characterizes the "administrative barrier" in terms of the demonopolization of markets. The economic content of administrative barriers is considered in detail in the work of V.Y. Voloshina]. The author reveals the administrative barriers in small and medium-sized settlements, as well as the main difficulties associated with the presence of such barriers (table 1). 
Table 1.

Contradictions in the interpretation of "administrative barriers".

\begin{tabular}{|c|c|c|}
\hline Author & Name the source & Approaches to the concept of \\
\hline $\begin{array}{l}\text { Nord } \\
\text { D.S. }\end{array}$ & $\begin{array}{l}\text { "Institutions, institutional } \\
\text { changes and the functioning of } \\
\text { the economy" }\end{array}$ & $\begin{array}{c}\text { Recognized in the institutional environment are "informal } \\
\text { constraints and ways to ensure the effectiveness of } \\
\text { restrictions». }\end{array}$ \\
\hline $\begin{array}{l}\text { Milner } \\
\text { B.Z. }\end{array}$ & $\begin{array}{l}\text { Preface to the work of DS North } \\
\text { "Institutions, institutional } \\
\text { changes and the functioning of } \\
\text { the economy"] }\end{array}$ & $\begin{array}{l}\text { The presence of barriers is considered as a characteristic } \\
\text { feature of institutions, defining them as "people- } \\
\text { developed limitations". }\end{array}$ \\
\hline Oleinik A.N. & $\begin{array}{l}\text { "Costs and prospects of reforms } \\
\text { in Russia: an institutional } \\
\text { approach". }\end{array}$ & $\begin{array}{l}\text { An analysis is given of the norms of the informal } \\
\text { institution, as well as norms belonging to the "ideal type". }\end{array}$ \\
\hline $\begin{array}{l}\text { Soto } \\
\text { E. De }\end{array}$ & $\begin{array}{l}\text { Another way. The Invisible } \\
\text { Revolution in the Third World " }\end{array}$ & $\begin{array}{c}\text { The following barriers are identified: business registration } \\
\text { costs, obtaining licenses, costs of continuing operations } \\
\text { under the law (payment of taxes, provision of mandatory } \\
\text { reporting). }\end{array}$ \\
\hline $\begin{array}{l}\text { Auzan } \\
\text { A.A., } \\
\text { Kryuchkova } \\
\text { P.V. }\end{array}$ & $\begin{array}{l}\text { «Administrative Barriers to the } \\
\text { Economy: Institutional } \\
\text { Analysis»] }\end{array}$ & $\begin{array}{l}\text { The definition of the concept of "administrative barriers" } \\
\text { is defined: as "the rules established by decisions of state } \\
\text { bodies, observance of which is a prerequisite for } \\
\text { conducting activities in the market, introducing payments } \\
\text { for the passage of bureaucratic procedures that usually do } \\
\text { not fall into the budget." }\end{array}$ \\
\hline $\begin{array}{l}\text { Perezenova } \\
\text { E.V. }\end{array}$ & $\begin{array}{l}\text { «Municipal Science: Theory, } \\
\text { Methodology, Practice» }\end{array}$ & $\begin{array}{l}\text { Isolated (endogenous) and external (exogenous) } \\
\text { contradictions in the market environment are singled out. }\end{array}$ \\
\hline $\begin{array}{l}\text { Petrov } \\
\text { I.V. }\end{array}$ & $\begin{array}{l}\text { «Demonopolization of markets } \\
\text { in the process of ensuring the } \\
\text { economic security of the } \\
\text { macroregion: a reproductive } \\
\text { approach»] }\end{array}$ & $\begin{array}{l}\text { The aspects of the market monopolization process under } \\
\text { market transformation conditions are considered. } \\
\text { The term "administrative barrier" is characterized as an } \\
\text { instrument for eliminating markets that are redundant in } \\
\text { terms of demonopolization. }\end{array}$ \\
\hline $\begin{array}{l}\text { Voloshina } \\
\text { V.Y. }\end{array}$ & $\begin{array}{l}\text { «The economic content of } \\
\text { administrative barriers and their } \\
\text { impact on the institution of } \\
\text { entrepreneurship»] }\end{array}$ & $\begin{array}{l}\text { The main difficulties that contribute to the existence of } \\
\text { administrative barriers in small and medium-sized } \\
\text { settlements are revealed: the lack of a developed market } \\
\text { inside the area; administrative pressure; difficulties of } \\
\text { entering the regional market. }\end{array}$ \\
\hline
\end{tabular}

Summarizing the contradictions and opposing the above-named scientists, in the opinion of the authors, the administrative barriers are of an economic and institutional nature, the actions (positive and negative effects) of which depend on the infrastructure and the state of the market environment.

Sociologist L. Thompson considers a set of norms and patterns of behavior in the context of the institutional market environment. We share the opinion of V.M. Polterovich argued that the institutional trajectories of catching-up development in successful countries included similar intermediary institutions; this similarity is due to the commonness of technological, institutional and cultural constraints that needed to be taken into account and overcome C. 34].

A more thorough analysis of administrative barriers is facilitated by the classification of barriers for a number of characteristics: access to resources; by the stage of the business process, on which this barrier is established and according to the conditions of the institutional environment.

As a result of the influence of administrative barriers on the market environment, externalities can appear in the form of market failures or negative external effects, which are expressed in various schemes of companies' departure from taxes, corruption, inflation, caused by institutional conflicts at the federal, meso-economic and local levels.

The effect of a barrier to the market environment can be positive, this is to ensure a stable income from the activities of enterprises and organizations, as well as the existence of security and social order: such barriers do not always promote active growth of the market, but nevertheless provide control over it. 
Acting as an instrument of state regulation, various forms of barriers are present in the most diverse spheres of economic activity, practically at all stages of economic activity of enterprises. J. Keynes for the first time justified the need and defined the main directions of regulation of the market economy, which retain their importance and at present.

In economic science, there are several options for classifying administrative barriers, the reasons for their appearance and the results obtained.

In the work of AA Auzan and PV Kryuchkova, the origin of the barrier is considered as a classification feature. In accordance with this classification, identify as barriers formed as a result of an erroneous decision of state bodies or a remnant of the past, as well as barriers that have arisen as a reflection of the personal interests of certain politically influential subjects or groups. In addition, the authors classify administrative barriers depending on the stage of the business process on which the barrier is located. This allows us to distinguish three groups of administrative barriers currently in force in Russia:

- barriers at the entry of enterprises to the market: licensing, permits, registration, approval of project documentation;

- barriers related to the admission of goods to the market: certification, identification, marking;

- "cost barriers": inspection activities, control and supervision, record keeping, document circulation, numerous forms of mandatory reporting.

According to the research of the Institute of the Economy in Transition], it is necessary to consider not only positive, but also negative aspects of barrier regulation. As a rule, most barriers are characterized by a negative impact on the activities of market entities, which does not exclude the possibility of a positive external effect (table 2 ).

Table 2.

The mechanism of barrier regulation

\begin{tabular}{|l|l|l|}
\hline The nature of the barrier & Effect of the barrier & Result of the barrier \\
\hline $\begin{array}{l}\text { 1. "Barriers of entry" to the market as } \\
\text { administrative obstacles to } \\
\text { entrepreneurial activity }\end{array}$ & $\begin{array}{l}\text { Create difficulties for small } \\
\text { and medium business }\end{array}$ & $\begin{array}{l}\text { Negative external effect in the form of } \\
\text { unregistered economic activity, failure } \\
\text { to pay taxes to the budget }\end{array}$ \\
\hline $\begin{array}{l}\text { 2. Control over the activities of } \\
\text { enterprises }\end{array}$ & $\begin{array}{l}\text { The absence of a limiter } \\
\text { during the control }\end{array}$ & $\begin{array}{l}\text { Limitations of competition in favor of } \\
\text { certain economic agents }\end{array}$ \\
\hline $\begin{array}{l}\text { 3. Contradictory requirements of a } \\
\text { legal nature }\end{array}$ & $\begin{array}{l}\text { The number of laws passed } \\
\text { does not provide the } \\
\text { required quality }\end{array}$ & $\begin{array}{l}\text { Structural shifts within the array of } \\
\text { laws are characterized by a negative } \\
\text { effect }\end{array}$ \\
\hline $\begin{array}{l}\text { 4. Sanctions for violation of the } \\
\text { established procedure for the } \\
\text { operation of enterprises }\end{array}$ & $\begin{array}{l}\text { Possibility to exert pressure } \\
\text { on the activities of } \\
\text { enterprises }\end{array}$ & $\begin{array}{l}\text { Negative effect in the form of slowing } \\
\text { down the pace of market development }\end{array}$ \\
\hline $\begin{array}{l}\text { 5. Adoption of normative acts on } \\
\text { control over entrepreneurial activity }\end{array}$ & $\begin{array}{l}\text { It is possible to adopt } \\
\text { normative acts that } \\
\text { unnecessarily restrict the } \\
\text { activities of enterprises }\end{array}$ & $\begin{array}{l}\text { Limitations of competition in favor of } \\
\text { certain economic agents, slowing the } \\
\text { growth of the market }\end{array}$ \\
\hline $\begin{array}{l}\text { 6. The combination by the same } \\
\text { agency of the functions of } \\
\text { establishing rules and monitoring } \\
\text { compliance with them }\end{array}$ & $\begin{array}{l}\text { Absence of the necessary } \\
\text { legal tools for the quality } \\
\text { work of agencies }\end{array}$ & $\begin{array}{l}\text { The nature of the impact on the } \\
\text { development of markets is negative, } \\
\text { the growth rate of markets is declining }\end{array}$ \\
\hline $\begin{array}{l}\text { 7. The lack of a clear mechanism for } \\
\text { price regulation }\end{array}$ & High inflation rate & $\begin{array}{l}\text { Decrease in sales, except for essential } \\
\text { goods }\end{array}$ \\
\hline
\end{tabular}

The regulation of administrative barriers in the new institutional environment seems to be a rather slow process, since it is connected with the change in inter-branch relations when the technological structures change and the mechanisms of self-regulation of the economy adapt to them. 
Nevertheless, barriers can become an effective tool that directs the economy of local markets to a rational path of development, provided that the market system has a self-regulatory mechanism at the local level. The positive external effect of administrative barriers can be obtained provided that regulation is one of the possible directions of state support for barriers at the meso-economic level.

There is an opportunity to increase the intensity of development of local markets by reducing the negative impact of administrative barriers.

Determining the degree of discrepancy between informal norms and formal rules becomes a fundamentally important task: the more requirements contradict each other, the stronger people will tend to ignore the rules imposed from above. C. Cornel and J. Calt suggest that the degree of disagreement be determined by four parameters: the structure of power relations; powers of authorities; the location of the authorities in the social structure; sources of power c. 405-406].

\section{Experimental section}

The research used general scientific methods: analysis and synthesis, as well as induction and deduction, aggregation and abstraction. A comparative analysis of the points of view of scientists on the notion of an "administrative barrier" has been carried out. The analysis of statistical data on loss-making enterprises, dynamics of arrears on wages is carried out.

\section{Results}

One example of the impact of barrier regulation on the market environment is the change in the procedure for paying insurance premiums for individual entrepreneurs in accordance with Federal Law No. 335-FZ of 27 November 2017:

- from 2018, insurance premiums for compulsory pension insurance will be calculated in the following order:

- if the amount of the payer's income for the settlement period does not exceed 300,000 rubles, - at a fixed amount of 2,545 rubles for the settlement period;

- if the amount of the payer's income for the settlement period exceeds 300,000 rubles, - at a fixed amount of 26,545 rubles for the settlement period plus $1.0 \%$ of the payer's income amount exceeding 300,000 rubles for the settlement period.

In 2017, the fixed pension contributions of the FE "for themselves" with incomes less than 300,000 rubles were 23,400 rubles. This amount was determined by a special formula, the outcomes from the minimum wage and the tariffs of insurance contributions. However, since 2018 a fixed amount of pension contributions will not depend on these values, but will simply be fixed in the law as 26,545 rubles.

Thus, since 2018 fixed pension contributions have increased by 3145 rubles: from 23400 rubles. up to 26545 rubles. Since 2018, all individual entrepreneurs, regardless of the conduct of business and income from business, will need to pay as compulsory pension contributions 26 545 rubles].

In the event that insurance premiums for IP exceed the level of the previous year, it can cause a massive rejection of the right to conduct activities by small businesses, or a partial transfer of small businesses to the unobserved (shadow) sector of the economy. The negative effect can eventually spread to consumers, as entrepreneurs need to raise prices to cover the costs of overcoming administrative barriers.

Mesoeconomic level is the average level of subsystems of the market environment: in the territorial aspect (regional aspect). Investigation of the laws of functioning of markets. Mesoeconomic level allows to assess the level of influence of administrative barriers on the development of the institutional market environment.

One of the possible ways to identify the impact of administrative barriers is to analyze the financial performance of organizations that have received a loss. Statistical observations of the territories of the Republic of Mari El over the period from 2010 to 2016 were made in the context of urban districts and municipal regions (Table 3 ). 
The financial result of loss-making organizations of the Republic of Mari El in the context of urban districts and municipal districts for 2010-2016, thousand rubles.

\begin{tabular}{|c|c|c|c|c|c|c|c|c|}
\hline $\begin{array}{l}\text { № } \\
\Pi / \Pi\end{array}$ & $\begin{array}{c}\text { Name of the } \\
\text { market }\end{array}$ & 2010 & 2011 & 2012 & 2013 & 2014 & 2015 & 2016 \\
\hline & \multicolumn{8}{|c|}{ Urban districts of the Republic of Mari El } \\
\hline 1 & Yoshkar-Ola & $\begin{array}{c}- \\
993159\end{array}$ & -846128 & -664285 & -847202 & -801337 & -4343431 & -585833 \\
\hline 2 & Volzhsk & $\begin{array}{c}- \\
192393 \\
\end{array}$ & -398793 & -257162 & -133771 & -191020 & -751463 & $\begin{array}{c}- \\
1387150 \\
\end{array}$ \\
\hline \multirow[t]{2}{*}{3} & Kozmodemyansk & -13068 & -9459 & -5208 & -11226 & -15367 & -4148 & -7598 \\
\hline & \multicolumn{8}{|c|}{ Municipal districts of the Republic of Mari El } \\
\hline 4 & Volzhsky & -50806 & -27726 & -38644 & -2847 & -5672 & -6326 & -27063 \\
\hline 5 & Gornomarisky & -4847 & 0 & 0 & -2302 & 0 & -144 & -652 \\
\hline 6 & Zvenigovsky & -30394 & -6620 & -13534 & -4074 & -236489 & -2785 & -249 \\
\hline 7 & Kielmar & -2585 & 0 & 0 & -285 & 0 & -1313 & -717 \\
\hline 8 & Kuzhenersky & -6421 & -21395 & -997 & -1563 & 0 & 0 & 0 \\
\hline 9 & Mari-Turek & -27174 & -31638 & -112355 & -1453 & -10055 & -3706 & -2852 \\
\hline 10 & Medvedevsky & -530614 & -112409 & -21975 & -1251009 & -19343 & -272069 & -283106 \\
\hline 11 & Morkinsky & -11303 & -9542 & -5596 & -3474 & -4448 & 0 & -2263 \\
\hline 12 & Novotoryalsky & -12283 & -854 & 0 & -241 & -108 & -25 & -834 \\
\hline 13 & Orshansky & -1754 & 0 & -11470 & -1208829 & -6582187 & -3602376 & $\begin{array}{c}- \\
1199980\end{array}$ \\
\hline 14 & Paranginsky & -4618 & -541 & -3926 & -11976 & -5 & -1906 & -324 \\
\hline 15 & Sernursky & -1998 & -3808 & 0 & -4522 & -1830 & -1609 & -3043 \\
\hline 16 & Sovietsky & -42093 & -7058 & -2295 & -33 & -4816 & -7476 & $\begin{array}{c}- \\
4800815 \\
\end{array}$ \\
\hline 17 & Yurinsky & -1749 & -1099 & -770 & -982 & -377 & -1249 & -1621 \\
\hline & Mari El Republic & -1927259 & -1477070 & -1138217 & -3485789 & -7873054 & -9000026 & $\begin{array}{c}- \\
8304100 \\
\end{array}$ \\
\hline
\end{tabular}

Compiled by: city districts and municipal districts of the Republic of Mari El. 2017: Statistical Digest /

Territorial Body of the Federal State Statistics Service for the Republic of Mari El. Yoshkar-Ola, 2017 - 268 p.

The results of the research show that in the Republic of Mari El during the period under review there is a tendency to increase the total amount of losses, which confirms the presence of limiting factors in the market environment.

Over the period from 2010 to 2012 there was a decrease in losses by $41 \%$, but starting from 2013, the total losses of organizations in the Republic of Mari El began to increase: from 2012 to 2013 there was a threefold increase in losses, further from 2013 to 2014 losses increased in 2 times. In 2014 there was a slowdown in the growth of losses of enterprises and organizations of the Republic of Mari El, it amounted to $14 \%$, further, there is a tendency to a slight decrease in losses by 7.7\%. Thus, for the period under review: from 2010 to 2016, the amount of losses of enterprises and organizations of the RME increased 4.3-fold.

In 2016, the bulk of losses in the context of urban districts and municipal areas falls on the Soviet, Orsha districts and the city of Volzhsk. Since 2010, the city of Yoshkar-Ola experienced the highest level of losses: from 2010 to 2012, the share of the loss in the city of Yoshkar-Ola in the total amount of losses in the Republic of Mari El was in the aisles from 51, $53 \%$ to $58.36 \%$.

In 2013, the highest level of losses was 35.89\% for Medvedevsky district and 34.68\% for the Orsha district, for Yoshkar-Ola the level of losses is 24.30\%. By the end of 2014, one can note the highest level of losses in the Orsha district $-83.6 \%$ of the total amount of the loss in the republic. In 2015, according to the city of Yoshkar-Ola, the share of unprofitable enterprises was 
$48.26 \%$, in Orsha district $-40.3 \%$, and in 2016 a high level of losses is recorded in the Soviet region $-57.81 \%$.

The presence of limiting factors or barriers, being the reason for the growth of the amount of losses of enterprises and organizations at the meso-economic level of the Republic of Mari El, indicates the presence of negative external effects (figure 1).

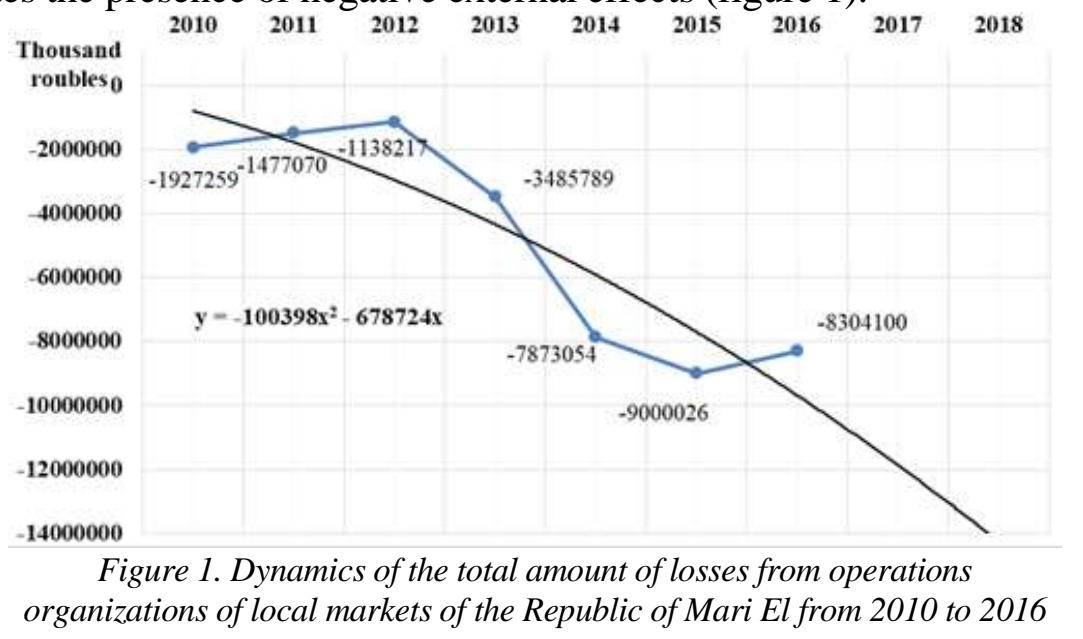

In addition to losses as a consequence of administrative barriers, it is possible to consider the emergence of arrears in the payment of employees' salaries. According to statistical data, wage arrears on the territory of the Republic of Mari El tend to decrease (figure 2).

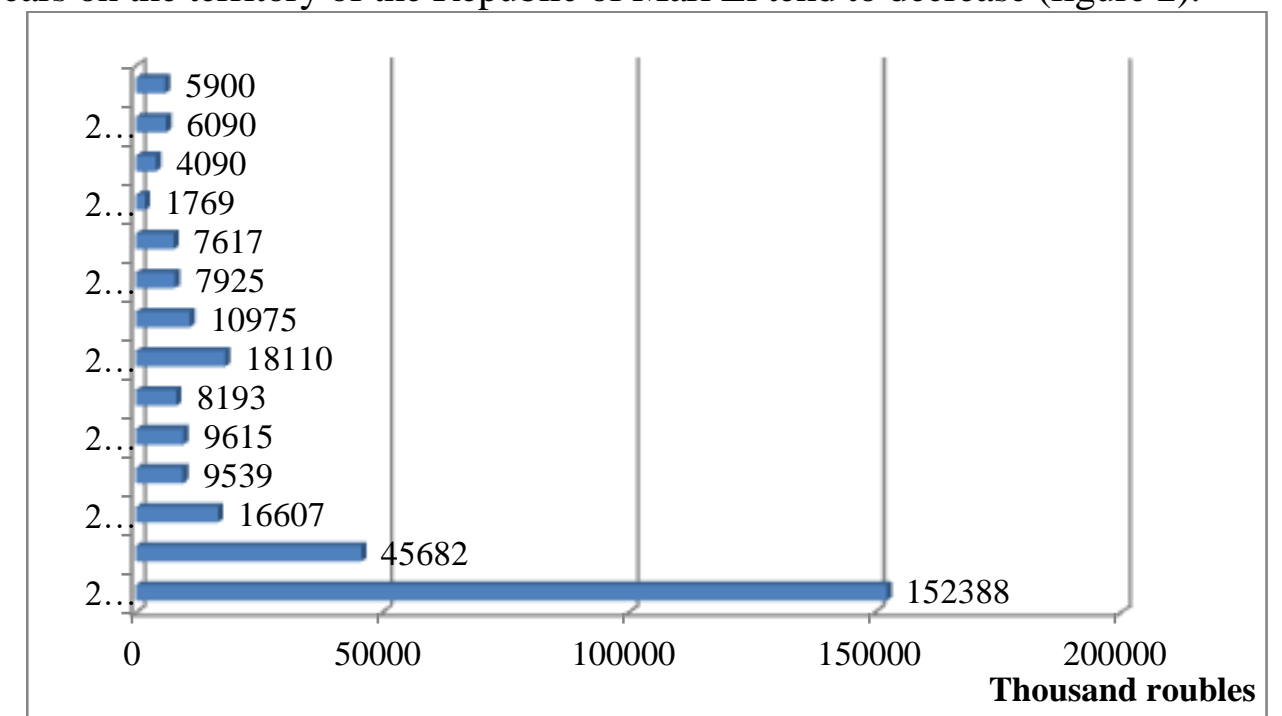

Figure 2. Dynamics of arrears of staff salaries Republic of Mari El from 2004 to 2016, thousand rubles.

Another fact that should be taken into account: often enterprises do not show the real wages of employees, which is also caused by the excessive nature of barrier regulation and leads to a negative external effect in the market environment. This reduces not only the taxable base, but also the level of social protection of employees.

\section{Discussion}

The main reasons for the arrears in wages were: the debt of customers for the work and services performed, the lack of financial resources in connection with the implementation of seasonal activities, the problems of selling products, a difficult financial situation due to lack of demand for products and goods, a decrease in production, low price for products. One of the main reasons is informal employment. In order to reduce it, interdepartmental commissions and working groups function in the republic. The practice of organizing their exit meetings in urban and rural settlements, conducting raids in conjunction with law enforcement, tax authorities and the prosecutor's office has proved to be very positive. In 2017, 4,800 outreach meetings were held with employers and employees. Legalized labor relations with 17 thousand people. 
employees, which is 1.8 times higher than the level of 2016 in accordance with the Agreement concluded between the Federal Service for Labor and Employment and the Government of the Republic of Mari El.

Along with this, meetings of the Interdepartmental Commissions on strengthening the payment discipline were held. In 2017, more than 78 meetings of territorial commissions were held, over three thousand employers were heard on issues of compliance with labor legislation, including labor remuneration. As a result of the work carried out in the Republic of Mari El in the course of 2017, 61 organizations with overdue wage arrears in the total amount of 113.4 million rubles were fixed. Compared to 2016, wage arrears decreased by 2.1 times.

During the implementation of the activities, 45 organizations partially or fully repaid the wage arrears in the amount of 72.0 million rubles.

However, both in the country and in the Republic of Mari El, there continues to be aggregate inequality (differentiation) in pay. Currently, 20.3 million citizens are below the subsistence minimum, and the difference in income is more than 15 times. This also applies to types of economic activity (branches of the economy). The lowest level of average wages is characteristic of workers in budget organizations (social services), and a high level in financial organizations and public administration [Ошибка! Источник ссылки не найден.].

\section{Conclusions}

To eliminate the above-mentioned problems, the following measures should be taken:

1) use of the infrastructure of the market environment, the mechanism of barrier regulation and the algorithm of the impact of administrative barriers proposed by the authors, having a preventive orientation of the negative consequences of economic and social development of the meso-economic level.

2) protection and promotion of the interests of the population and business in government bodies, increasing the number of norm-setting initiatives adopted to reduce administrative barriers, tax burden and labor safety;

3) increasing the social responsibility of employers for creating a business and investment climate, healthy competition and ensuring the effective employment of workers with decent pay;

4) development of human potential through the creation of modernized jobs and the training of skilled personnel and the balance of labor supply and demand.

Barrier regulation should be aimed at maintaining a balance in the market environment of positive externalities and minimizing the negative consequences that arise as a result of excessive administrative barriers. In the future, based on research, depending on the nature of the external effects obtained, it is possible to develop a strategy for the development of markets for the mesoeconomic level of the Republic of Mari El.

The article was prepared with the support of the Russian State Fund for Fundamental Research (FBBOU) under the grant No. 18-010-0099019

$$
* * *
$$

1. Russian Microfinance Center [Electronic resource] URL: ttp: //www.rmcenter.ru/about/news/5603/ (circulation date is 30/04/2018).

2. North, D. C. Structure and Change in Economic History. N.Y., 1981. - P. 16.

3. Milner, B. 3. Preface to the work of D. North "Institutions, institutional changes and functioning of the economy" / B. 3. Milner. M .: Start. - 1997.

4. Oleinik, A.N. Costs and prospects of reforms in Russia: an institutional approach / AN Oleinik. M: Master. - 1997.

5. De Soto, E. Another way. Invisible revolution in the third world / E. De Soto. M .: Gatallaxy. - 1995.

6. Coase, R. The Problem of Social Cost // Journal of Law and Economics. 1960. Vol. 3. No. 1. - P. 21. Coase R.H. The Firm, the Market and the Law. Chicago and London, 1981 (p., Ne .: Koyz P., M., 1993). - P. 25.

7. Auzan, A. Administrative barriers in the economy: the task of releasing / A. Auzan, P. Kryuchkova // Questions of Economics. 2001. - No. 5. - P. 73.

8. Municipal science: theory, methodology, practice. M .: The municipal world. - 2003. 
9. Petrov, I.V. Demonopolization of markets in the process of ensuring the economic security of the macroregion: the reproduction approach / IV Petrov. - M .: Unity. - 2005. - P. 58-61.

10. Voloshina, V.Y. Economic content of administrative barriers and their impact on the institution of entrepreneurship: thesis of Cand. econ. Sciences: 08.00.01. Voloshina Valentina Yurievna. - Rostov n / a: RSL, 2007. [Electronic resource] URL: http://economy-lib.com/ekonomicheskoe-soderzhanieadministrativnyh-barierov-i-ih-vozdeystvie-na-institut-predprinimatelstva (reference date is 30.04. 2018).

11. Tompson, W. Hickey J. Society in focus: an introduction to sociology. N.Y., 1993. - P. 12-14.

12. Polterovich V.M. Institutes of catching-up development (to the draft of a new model of economic development of Russia). - Economic and social changes: facts, trends, forecast. - No. 5 (47). - 2016. - P. 34 56.

13. Keynes, J.M. The General theory of employment, interest and money.

14. Deregulation of the Russian economy / VA Mau, SV Zhavoronkov, DS Cherny, KE Yanovskiy. M., 2001. [Electronic resource] URL: https://www.iep.ru/en/publikatcii/publication/968.html (circulation date is 30/05/2018).

15. Petrov, A. Innovative-breakthrough way of development: forecast parameters / A. Petrov, I. Pospelov // Economist. - 2007. - No. 1. - P. 15.

16. Cornell, S., Kalt, J., Where does economic development really come from? Constitutional Rule Among Contemporary Sioux and Apaxche // Economic Inquiry. Vol. 33, July, 1995. - P. 34.

17. Official website Consultant Plus [Electronic resource] Federal Law "On Amending Part One and Two of the Tax Code of the Russian Federation and Certain Legislative Acts of the Russian Federation" dated 27.11.2017 N 335-FZ (last revised) Url: http: // www.consultant.ru/document/cons_doc_LAW_283495/ the date of the last accession was 16/04/2018).

18. Official site Online magazine for the accountant. Insurance premiums of IP for themselves in 2018: how to calculate and pay [Electronic resource] Url: https://buhguru.com/strahovie-vznosy/strah-vznosy-ip-s-2018goda.html (the date of the last accession was 16/04/2018).

19. Chernykh, V. V. Local markets of the Republic of Mari El: patterns of functioning and development opportunities: monograph / V. V. Chernykh. - Yoshkar-Ola: Volga State Technological University, 2015. $160 \mathrm{p}$.

20. Adrianov, Y. Tripartism as the factor of development of the higher school / Y. Adrianov, L. Nizova, T. Sannikova // Journal of Applied Engineering Science. - jaes. - 2017. 


\title{
РАЗДЕЛ ХV. МЕНЕДЖМЕНТ
}

\author{
Блинов С.B. \\ Совершенствование системы управления персоналом в негосударственном \\ учреждении здравоохранения \\ ЧУОО ВО «Медицинский университет «Реавиз» \\ (Россия, Самара)
}

doi: $10.18411 /$ scienceconf-05-2019-53

idsp: scienceconf-05-2019-53

\section{Аннотация}

Развитие системы здравоохранения Российской Федерации требует системного и комплексного к совершенствованию организационной системы управления персоналом. Основным инструментом решения проблем HRM может стать организационная кадровая политика.

Ключевые слова: системный подход, организация, негосударственное (частное) учреждение здравоохранения, лечебно-профилактическое учреждение, стратегическое управление, кадровый менеджмент, HRM, кадровая политика, цели и задачи.

Abstract

The Development of the health care system of the Russian Federation requires a systematic and comprehensive improvement of the organizational system of personnel management. The main tool for solving HRM problems can be organizational personnel policy.

Keywords: system approach, organization, non-governmental (private) health care institution, medical and preventive institution, strategic management, personnel management, HRM, personnel policy, goals and objectives.

Реформирование здравоохранения Российской Федерации требует принципиально новых подходов к пониманию ценности кадровой составляющей. Перспективы развития отечественного здравоохранения в значительной степени зависят от качества подготовки, компетентности, профессионального опыта медицинских и фармацевтических кадров. Медицинские работники, являясь наиболее значимой имиджевой составляющей здравоохранения, обеспечивают эффективность деятельности учреждений.

При решении вопроса совершенствования кадрового менеджмента (HRM) лечебно-профилактических учреждений представляется целесообразным применение системного подхода. Основным инструментом решения проблем HRM может стать организационная кадровая политика.

В качестве основной цели кадровой политики негосударственного (частного) учреждения здравоохранения (НУЗ) может быть обозначено - повышение и поддержание достаточного уровня конкурентоспособности НУЗ на рынке медицинских услуг за счет кадровой составляющей в первую очередь.

Рассматривая в качестве примера НУЗ ОАО «РЖД», необходимо отметить принципиально важные моменты. Для достижения основной цели кадровой политики следует решить ряд задач:

- разработать и реализовать комплекс мероприятий, ориентированных на укрепление позитивного имиджа и повышение престижа работы в здравоохранении ОАО «РЖД»;

- совершенствовать систему оплаты труда и стимулирования работников НУЗ; сформировать корпоративный заказ на подготовку медицинских работников, в том числе «узких» специалистов в соответствии с задачами и перспективами развития здравоохранения компании;

- обеспечить профориентационные мероприятия для молодых специалистов выпускников высших медицинских учебных заведений и медицинских училищ (колледжей); 
- разработать программы мотивации привлечения, удержания (в том числе для высококлассных специалистов территориальных учреждений здравоохранения) и побуждения к эффективному труду;

- сформировать и актуализировать кадровый резерв на руководящие должности;

- обеспечить своевременную территориальную, горизонтальную и вертикальную ротацию кадров;

- организовать качественную и своевременную первичную специализацию, переподготовку и повышение квалификации медицинских кадров, в том числе в системе непрерывного медицинского образования (НМО);

- совершенствовать систему охраны труда и обеспечить безопасность труда работников учреждения здравоохранения.

Комплекс мероприятий, ориентированных на укрепление позитивного имиджа и повышение престижа работы в здравоохранении ОАО «РЖД», должен обеспечить устойчивое восприятие НУЗ ОАО «РЖД» как ответственного работодателя, гарантирующего справедливую систему оплаты труда, эффективные методы стимулирования и мотивации, возможности карьерного роста, обучения и развития; высокий уровень социальной защиты работников и членов их семей, пенсионеров железнодорожного транспорта, в том числе добровольное медицинское страхование работников и членов их семей, негосударственное пенсионное страхование, прочие льготы, предоставляемые в соответствии с коллективным договором.

Совершенствование систему оплаты труда и стимулирования работников НУЗ в условиях превалирования уравнительных подходов к оплате труда медицинских работников, отсутствия реальных стимулов к повышению качества медицинских услуг, низкой мотивация к применению непрофильных ранее и приоритетных сейчас профилактических видов деятельности, приобретает приоритетное значение.

Прогнозирование потребности в медицинских и фармацевтических работниках позволит сформировать корпоративный заказ на подготовку медицинских работников, в том числе «узких» специалистов, в соответствии с задачами и перспективами развития НУЗ и применять трехсторонние договоры с целью перспективного закрепления специалистов, подготовленных за счет средств учреждения. В решении этого вопроса помогут профориентационные мероприятия для студентов и выпускников высших и средних медицинских учебных заведений.

Для привлечения молодых специалистов и зарекомендовавших себя медицинских работников регионального и федерального уровня, имеющих высокий рейтинг, потребуются специальные мотивационные программы, направленные на привлечение, удержание и побуждение работников к эффективному труду, предусматривающие различные формы монетарной и немонетарной мотивации: управление карьерой, обучением и развитием, ротацией; организация рабочего места и пр.

Формирование и актуализация кадрового резерва, использование эффективных программ отбора претендентов на занятие руководящих должностей, и специальных программ формирования управленческих компетенций обеспечат своевременную территориальную, горизонтальную и вертикальную ротацию кадров. Особое внимание необходимо будет уделить мониторингу оценочных показателей резервистов и срокам пребывания в составе кадрового резерва. Это обеспечит комплектование штатных руководящих должностей наиболее подготовленными и перспективными медицинскими работниками системы здравоохранения ОАО «РЖД», обладающими специфическими идиосинкразическими знаниями структуры и специфики компании, и способными приступить к исполнению новых должностных функций практически без адаптационного периода.

Организация качественной подготовки, переподготовки и повышения квалификации медицинских работников с учетом запроса компании требует обязательного включения в программы вопросов обеспечения безопасности движения, экспертизы профессиональной пригодности на железнодорожном транспорте, организации работ по ликвидации медицинских последствий чрезвычайных ситуаций на железной дороге. И, кроме того, обеспечивает освоение и применение уникальных методик диагностики, лечения и реабилитации и использование медицинского 
оборудования экспертного класса, в том числе диагностического, не имеющих аналогов в учреждениях регионального здравоохранения.

Изменения, происходящие в ОАО «РЖД», касаются и здравоохранения компании. Основными показателями эффективности реформирования НУЗ обозначены: качество оказываемой медицинской помощи, удовлетворенность пациентов (отсутствие обоснованных жалоб), доля внекорпоративных источников финансирования, рост производительности труда, доходы на 1 работника, длительность пребывания в стационаре и работы койки. Соответственно, основными видами деятельности главных врачей (директоров) стали стратегическое планирование; HRM, бюджетирование, в том числе формирование консолидированного бюджета, поиск инвестиций, оперативный контроль и анализ деятельности структурных подразделений НУЗ.

Стратегическая задача HRM в нынешних условиях развития здравоохранения компании - формирование работоспособной команды, воспринимающей себя неотъемлемой составной частью организации, сплоченной единой целью и заинтересованной в результате своего труда. Необходимо формирование адаптивной системы HRM, выстроенной по принципу эффективной прямой и обратной связи и призванной способствовать повышению эффективности деятельности учреждения здравоохранения. Любая организация, ориентированная на создание и развитие таких команд, окажется более подготовленной к постоянным изменениям, обновлению и освоению новых рынков.

Важнейшим элементом HRM становится индивидуально-ориентированный подход к развитию профессиональных, менеджериальных и социальных компетенций сотрудников, а принципиально важным моментом - оценка компетенций сотрудников и уровня их мотивации к результативной, творческой, инновационной деятельности, выполнению различных задач (мультифункциональность), адаптивности и мобильности._Сложная и постоянно меняющаяся рыночная среда требует от каждого руководителя компетентности и гибкости, поскольку именно на них возлагается персональная ответственность за достижение заданных эффективности деятельности.

Подводя итог вышесказанного, можно сделать вывод о приоритете HRM руководителю следует сконцентрировать внимание, инвестиции и усилия на кадровой политике, обеспечивающей планомерное развитие каждого работника и всего трудового коллектива в соответствии с целями и задачами организации.

$$
\text { *** }
$$

1. Блинов С.В., Ревина С.Н., Кузьмина Н.М. Формирование и внедрение системы ключевых показателей эффективности деятельности и оценки качества медицинских услуг НУЗ ОАО «РЖД» (на примере НУЗ «ДКБ на станции Самара ОАО «РЖД») // Экономические науки, 2016. - № 6 (139). - C. $20-25$.

2. Блинов С.В., Ревина С.Н., Кузьмина Н.М. Актуальные проблемы формирования системы целевых показателей эффективности деятельности учреждений здравоохранения// Вопросы экономики и права, 2017. - № 3. - С. 83-90.

3. Друкер П. Эффективный управляющий. - М.: Издательство Манн, Иванов и Фербер, $2015-240$ с.

4. Кузьмина Н.М. Кадровая политика корпорации. ИНФРА - М, Научная мысль, 2016. -168 с. 


\section{РАЗДЕЛ ХVІ. ПЕДАГОГИКА}

\section{Баранникова Т.Б., Казиахмедова С.X. \\ Компаративные фразеологические единицы как средство формирования межкультурной компетенции в условиях полиэтнической среды}

Дагестанский государственный педагогический университет, Дагестанский государственный университет (Россия, г. Махачкала) Московский государственный гуманитарно-экономический университет (Россия, г. Москва)

doi: 10.18411/scienceconf-05-2019-54

idsp: scienceconf-05-2019-54

\section{Аннотация}

Настоящая статья выполнена в русле исследований, посвященных специфике обучения межкультурной коммуникации в многоязычной и поликультурной среде. В задачи исследования входит разработка приемов формирования межкультурной компетенции полиэтнического контингента обучающихся дагестанского вуза на основе компаративных фразеологических единиц.

Ключевые слова: межкультурная компетенция, полиэтническая среда, компаративные фразеологические единицы.

\section{Abstract}

The article covers the problem of intercultural communication training in a multilingual and multicultural environment. It aims at the formation of intercultural competence of a polyethnic contingent of Dagestani students on the basis of comparative phraseological units.

Key words: intercultural competence, multi-ethnic environment, comparative phraseological units.

В современных условиях сближения народов и усиления межкультурного взаимодействия особенно актуальным становится изучение иностранных языков в их культурном контексте. При этом овладение иностранным языком рассматривается как возможность развития личности посредством соприкосновения с другой культурой. В языковом образовании происходит становление новой парадигмы - межкультурной. Многие современные исследователи в качестве основной цели обучения иностранным языкам определяют формирование межкультурной компетенции (Н.Д. Гальскова, Г.В. Елизарова, Е.В. Малькова, П.В. Сысоев, Н.С. Тырхеева, А.Н. Щукин и др.). В рамках данной парадигмы возникает необходимость не только грамотно использовать языковые средства иностранного языка, но и понимать иную культуру, сравнивая ее с родной.

В условиях национально-русского двуязычного педагогического общения возможности для развития межкультурной компетенции учащихся полиэтнических регионов значительно возрастают, т.к. обучающиеся готовы к встрече с новым языком и культурой. Ср. с правомерным утверждением Н.Д. Гальсковой и Н.И. Гез [4], что Россия как полилингвоэтнокультурное государство дает колоссальные дополнительные возможности для реализации целей и задач межкультурного обучения и межкультурной компетенции. В то же время, это означает и усложнение условий самореализации, так как учащиеся вынуждены находиться в измерениях сразу трех (а иногда более) различных культур.

В современной лингводидактике проблема межкультурного обучения иностранным языкам в условиях, отличных от регионов с однородным по национальному составу населением, рассматривается в рамках формирования поликультурной языковой личности: [5, 8 и др.]. Проблема обучения иностранному языку в условиях многоязычия, 
особенно актуальная для такого многонационального региона Российской Федерации, как Республика Дагестан, привлекала внимание и дагестанских исследователей [6 и др.], однако она не может не нуждаться в дальнейшей разработке в современном контексте обучения учащихся межкультурной коммуникации.

Объектом исследования в настоящей публикации является процесс обучения межкультурной коммуникации в условиях поликультурной среды дагестанского вуза. Предметом исследования является методы и приемы, позволяющие выстроить систему работы по формированию межкультурной компетенции студентов-лингвистов на основе компаративных фразеологических единиц английского языка с привлечением материалов русского и родных языков.

Выбор компаративных фразеологических единиц в качестве средства формирования межкультурной компетенции обусловлен тем, что наиболее ярко межкультурные различия проявляются, прежде всего, на материале фразеологии. Компаративные фразеологические единицы (КФЕ), обладающие выраженным национально-культурным содержанием и ведущие к более глубокому пониманию национальной картины мира, как чужой, так и своей, могли бы представлять значительный интерес для лингводидактов, разрабатывающих вопросы методики обучения межкультурной коммуникации, однако в данном аспекте и в условиях многоязычия они довольно слабо изучены и практически не встречаются в содержании рабочих программ, учебников, методических разработок, предназначенных для рассматриваемого контингента студентов .

Актуальность данного исследования, таким образом, связана с

- необходимостью формирования у студентов вуза с многонациональным и поликультурным контингентом способности к осуществлению межкультурной коммуникации и недостаточной сформированностью межкультурной компетенции студентов, не позволяющей полноценно участвовать в диалоге культур;

- необходимостью формирования межкультурной компетенции у студентов на основе фразеологических единиц иностранного и родного языков и недостаточной разработкой методики обучения их фразеологии в условиях многонационального вуза.

-высокой значимостью компаративных фразеологизмов аспекте обучения межкультурной коммуникации и недостаточным вниманием к ним со стороны лингводидактов.

В реализации поставленной задачи мы опирались на уже имеющейся опыт включения ФЕ в содержание обучения иностранному языку. Базой экспериментальноопытного обучения послужил факультет иностранных языков Дагестанского государственного педагогического университета. Экспериментальное обучение предварял разведывательный эксперимент, нацеленный на проверку знания испытуемыми КФЕ английского языка. В качестве форм контроля использовались тесты, а также задания на выявление общих и специфических характеристик в английской, русской и дагестанской лингвокультурах, применялся ассоциативный эксперимент и анкетирование.

На обучающем этапе эксперимента работа со студентами экспериментальной группы по формированию межкультурной компетенции на основе компаративных фразеологических единиц проводилась в соответствии с отобранными методами и приемами обучения. Были использованы все три вида методов, выделяемые в соответствии с характером участия в процессе обучения : пассивные, активные и интерактивные. Пассивные методы были представлены, прежде всего, лекционным методом. На вводной лекции студенты познакомились с краткой историей изучения компаративных фразеологических единиц в общем, частном и сопоставительном языкознании. Особое внимание при этом было уделено анализу сопоставительных исследований КФЕ на материале дагестанских языков, выполненных как в одноязычном, так и сопоставительном аспектах $[1,2,3,7$ и др.]. Второй из реализуемых методов проблемно-поисковый. Студенты работали со словарями, выполняли разные виды 
лингвистического анализа КФЕ, решая ключевую проблему: как отразились в данных единицах реалии жизни его носителей. В числе активных методов обучения практиковались выступления участников экспериментальной группы с краткими сообщениями по теме исследования. Применялись и интерактивные методы - обучение общению в системе диалога (полилога).

Что касается приемов и способов презентации КФЕ, при их семантизации мы обращали внимание учащихся на их "внутреннюю сторону" и стремились дать дословный перевод, который может помочь понять специфику этих единиц, а также лучше их запомнить. Испытуемым было предложено распределить отобранный материал исследования на три группы в соответствии со степенью семантического сходства элементов. Первую, сравнительно немногочисленную группу сопоставляемых компаративных фразеологических единиц образуют полные эквиваленты:

англ. as cunning as a fox «хитрый как лиса», в лезгинском сикI хьтинди, в лакском иулчlа куна хІиллакарсса, в даргинском ккурттагван гlямалтар, аварском иер гlадин «хитрый как лиса» и др.;

англ. as stubborn as a mule «упрямый как осел», в лезгинском: лам хьтинди, в лакском вилицун куна хІиркІбувгьусса, в даргинском: эмгьагван бастукь «упрямый как осел».

Наиболее широко представлена вторая группа сопоставляемых фразеологических единиц, включающая частичные эквиваленты:

англ. as red as a lobster «красный как рак» - в лакском ажсарттул эччу куна ятІлу ичин «покраснеть как петушиный гребешок», в даргинском байракъгван итІинил «красный как флаг», иІукка итІинил «красный как уголек»;

англ. clean as a whistle «досл. чистый как свисток», в русском «чистый как стеклышко», в лакском кьуръанналуллу куна марицІссаикІан «чистый (честный) как коран», в даргинском лямиІикІул дягІимиІалгван «чистый как зеркало»;

англ. like a scalded cat «как обваренная кошка», в русском «как угорелая кошка», в лакском ччан ччувччусса ккаччи кунма «как собака с обожженной ногой», в даргинском гъвагъва ицІалипгван къачІли (быстрый как гром и молния), иџа букъара ијарунилгван (какбудто за огнем пришла);

англ. shake like a leaf «дрожать как лист», в русском «дрожать как осиновый лист» - в лакском нувиІуйсса щивщу кунма гьалак буккан «как пшеница на жаровне» - в даргинском хъарагван рурччул «как фасоль при кипячении»;

англ. as round as a barrel «толстый как бочка» - в лакском къячlи куна дучсса «толстый как кувшин», в даргинском къаппгван вицІурил (букв. как мешок полный); в аварском гьанал михир гlaдав (букв. как каток из мяса).

К третьей группе относятся фразеологические единицы, которые не имеют эквивалентов в сопоставляемых языках. Среди английских безэквивалентных фразеологических единиц по отношению к дагестанским можно выделить, например: as cold as charity (букв. холодный как милость, благодеяние); as cross as a bear with a sorehead (букв. злой как медведь с больной головой); (as) wise as Solomon « книжн. мудрый как Соломон», (as) tall as a maypole - «высокий как майское дерево (украшенный цветами столб, вокруг которого танцуют 1 мая в Англии)», to grin like a Cheshire cat «усмехаться как чеширский кот» и др.

Среди безэквивалентных компаративов лакского языка можно отметить, например: Бархъаллал жалин кунма «как балхарская невеста (нарядная)», Идавсил ПатІимат кунма «безгрешная, чистая душа» (букв. как дочь пророка Патимат), кюрттаравун ялугьлагьисса ччитул оьрчІру «человек с несбыточными мечтами» (букв. котята, смотрящие в гнездо), лажин кІяла овл (букв. белолицая корова - подхалимка). Примерами безэквивалентных даргинских компаративов являются, например, гъай адаргьан ГІямурагван «как немая Ашура», в аварском хъабчиль наи 1 гlaдин «неотвязно», «назойливо», «как банный лист», (букв. как вошь в шубе), чlараб гъобо гlaдин «тихо», 
«печально»( букв. как остановившаяся мельница), мажсгиталда 6аxlpu гladин «не на своем месте», (букв. как бродячая собака в мечети) и др. Семантика КФЕ лезгинского языка отличается наличием оборотов, в основу которых вложена ирония: маймун хьтинди «красивый как обезьяна» .

Специфической чертой нашего экспериментального обучения явилось внеаудиторное выполнение научно-исследовательской работы по выявлению лексических групп КФЕ рассматриваемых языков и составлению фрагментов двух- и трехъязычных словарей КФЕ (английский, русский, дагестанские языки), Принципами отбора КФЕ в учебных целях являлись: 1. Семантическая ценность - отобранный нами языковой материал включал КФЕ, которые обслуживают процесс обучения, т.е. отражает темы, которыми должны овладеть учащиеся на занятиях по английскому языку. 2. Коммуникативная ценность. В учебный словарь включались КФЕ, которые характеризуются собственным, отличным от слова значением, а также активным употреблением; 3. Страноведческая ценность. Включались КФЕ, содержащие в себе безэквивалентную, фоновую лексику. 4. Учет системных связей.

Подобные разработки, нацеленные на отражение национально-культурного своеобразия фонда устойчивых сравнений, могут в дальнейшем послужить основой для составления словаря КФЕ, адресатом которого выступили бы учащиеся, изучающие английский язык в условиях полиэтнической и поликультурной среды на продвинутом и завершающем этапах обучения.

Результаты обучающего эксперимента подтвердили выдвинутую рабочую гипотезу и позволили констатировать эффективность экспериментального обучения, подтвердившего, что изучение КФЕ может стать одной из основ формирования межкультурной компетенции в единстве с развитием языковой способности студентовлингвистов.

В итоге проведенной работы по внедрению КФЕ в учебный процесс формирования мкК представляется возможным сделать вывод, что знание своеобразия фразеологии английского языка в сравнении с русским и родным языками может способствовать успешности межкультурного общения. К возможным рекомендациям по формирования межкультурной компетенции студентов многонационального вуза могут быть отнесены следующие:

- использовать методическую систему, разработанную в соответствии с учётом родного языка, принципами речевого развития и коммуникативной компетенции учащихся;

- практиковать научно-исследовательскую работу студентов по составлению учебных двух- и трехъязычных словарей-минимумов КФЕ;

- совершенствовать содержание рабочих программ, учебников, составлять методические разработки с целью рекомендации в них системы обучения культурно маркированным фразеологическим единицам как средству обучения межкультурной коммуникации.

$$
* * *
$$

1. Абдулкадырова П.М. Компаративные фразеологические единицы даргинского языка в сопоставлении с английским (на материале хайдакского диалекта) : Автореф. дисс. ... к. ф. н.: Махачкала: 2010. 24c.

2. Гаджиева Л. Г., Абдулкадырова П. М. Сопоставительный анализ компаративных фразеологических единиц в английском, лакском и даргинском (хайдакский диалект) // Известия ДГПУ.Т. №1, Махачкала: 2015.c. 63-66.

3. Гаджиева С. Г. Структурно-семантические особенности компаративных фразеологических единиц лакского языка: Автореф. дис. канд. филол. наук. Махачкала, 1995. 24c.

4. Гальскова Н.Д., Гез Н.И. Теория обучения иностранным языкам: Лингводидактика и методика. М., 2004. 
5. Зиятдинова Ю. Н. Развитие межкультурной компетенции студента технического вуза в условиях полиэтнической среды Республики Татарстан [Текст] : монография / Ю. Н. Зиятдинова, Э. Э. Валеева, А. Ф. Мирзанурова . Казань : Центр инновационных технологий, 2012. 151 с.

6. Ильясов И.О. Методика обучения английскому языку учащихся многонациональных школ. Махачкала: Дагучпедгиз, 1996. 150 с.

7. Пайзулаева 3.Х.. Компаративные фразеологические единицы аварского и английского языков : Автореф. дисс. ... канд. филол. наук. Махачкала, 2010. 25с.

8. Фомин М.М. Формирование межкультурной компетенции в условиях диалога культур // Историческая и социально-образовательная мысль. 2012. №5 (15). С.95-99.

\title{
Гузанов Б.Н., Федулова К.А. \\ Формирование критического отношения к информации при компьютерной подготовке студентов профессионально-педагогического вуза
}

\author{
ФГАОУ ВО «Российский государственный \\ профессионально-педагогический университет»
} (Россия, Москва)

doi: $10.18411 /$ scienceconf-05-2019-55

idsp: scienceconf-05-2019-55

Сегодня вопросы комплексной информатизации общественного развития занимают ключевое значение, и данный фактор влияет на динамику социальных процессов и определяет тенденции общественного развития. Становление и развитие нового информационного общества затрагивает всю инфраструктуру современного социума, изменяя его экономические, социальные, политические, культурологические и философские аспекты, среди которых особое место занимает образование. При таком подходе важнейшей характеристикой информационного общества становятся принципиально новое устройство, при котором главным ресурсом являются информация и знания. В последние годы стремительно растет и множится объем знаний, накопленных человечеством, что существенно изменяет характер производственных отношений между людьми, когда основными производственными процессами выступают процессы передачи, обработки и поиска информации на основе использования современных информационных технологий.

Умение использовать информационные и коммуникационные технологии в качестве инструмента в профессиональной деятельности, обучении и повседневной жизни во многом определяет успешность современного человека, позволяет ему приобретать новые способности и сохранять конкурентоспособность на рынке труда при изменениях в сфере профессиональной занятости. Другими словами, высокий уровень обобщенных профессиональных знаний, владение системой обобщенных приемов и умений, способность эффективно их применять для выполнения производственных заданий в сфере своей профессии определяет условия и основу трудовой мобильности будущих специалистов, в том числе и профессионально-педагогических кадров.

Для реализации принципа профессиональной мобильности подобным работникам необходимо заниматься самообразованием и повышением собственной квалификации, для чего им приходится использовать все возможные источники информации, среди которых самым ресурсоемким выступает Интернет. Кроме того, появление и развитие виртуальных университетов, дистанционного образования и мобильных электронных школ повсеместно вошло в систему уровневого образования, что требует от педагогов разработки и поддержки соответствующих виртуальных ресурсов, размещаемых в информационно-образовательной среде конкретной организации, которая также располагается и поддерживается через сервисы всемирной информационной сети.

Особо следует отметить, что сегодня высока потребность в преподавателях, способных быстро реагировать на требования работодателей в части подготовки рабочих и специалистов среднего звена для нужд высокотехнологичного производства. В связи с этим особое значение приобретает, как показано в работе, уровень профессиональной компетентности профессионально-педагогических кадров, основную часть которых составляют педагоги профессионального обучения, организующие учебнопознавательные и учебно-производственные процессы в образовательных учреждениях различного уровня и в учебных центрах на производстве. 
Специфика профессиональной деятельности современного педагога профессионального обучения определяется двумя ее относительно обособленными составляющими - отраслевой (технико-технологической) и педагогической, причем их следует рассматривать только сбалансировано, включая общие и специфические составляющие этих компонентов]. Можно сказать, что в методологическую основу подготовки кадров профессионально-педагогического образования изначально заложены интеграционные принципы, когда педагогическая и отраслевая (техникотехнологической) составляющие подготовки существуют не сами по себе, а выстроены в закономерный логический ряд, образующий синергетическое единство.

Современные информационные технологии призваны стать стержнем профессионально-педагогической деятельности, объединить и интегрировать техническое и педагогическое знание, что имеет особое значение в условиях совмещения в рамках одной образовательной программы различных по своей направленности профессионально-специализированных дисциплин. Именно ИКТ позволяют осуществлять проектирование и моделирование образовательного процесса, в частности, через визуализацию и виртуализацию объектов профессиональной подготовки, а также производить анализ и синтез технологических процессов и систем с возможностью их дальнейшей модификации и оптимизации.

Технологии компьютерного моделирования, интегрированные в информационную подготовку современного педагога профессионального обучения, способствуют развитию у обучающегося навыков саморазвития и самообразования, повышают учебнопознавательную активность, позволяют освоить технологию командной работы и подготавливают к возникающим в будущей профессионально-педагогической деятельности нестандартным и сложным ситуациям. Можно сказать, что компьютерное моделирование в современных условиях становиться одной из основных технологий организации подготовки педагогов профессионального обучения, которая дает возможность сформировать у будущих выпускников готовность к проектированию образовательного пространства средствами информационных технологий.

В процессе создания информационных моделей формируются умения, позволяющие анализировать объекты моделируемой области действительности, выделять у них общие признаки и на основе этого выбирать основания для их классификации с последующей группировкой объектов по классам, устанавливая отношения между ними с изменениями значений выделенных ранее признаков. После завершения анализа необходимо выполнить проектирование и синтез модели средствами информационных и коммуникационных технологий. Все перечисленные умения предполагают развитие навыков алгоритмического, клипового и net-мышления, составляющих основу информационного.

В рамках формирования информационного стиля мышления перед обучаемым ставится задача практического овладения методами аналитико-синтетической обработки информации, формирование умения связывать факты, понятия в одну систему, умения мысленно их компоновать в единое целое, корректно интерпретировать и использовать. Отмечается, что информационный стиль мышления позволяет выработать умение четко ориентироваться в быстроменяющейся информационной ситуации, правильно оценивать сложившуюся обстановку и принимать соответствующие решения, используя при оценке альтернатив рациональные, эстетические и морально-этические критерии на основе критического отношения к анализируемой информации.

Информационная подготовка, основанная на технологиях компьютерного моделирования, предполагает нешаблонное использование информационных и виртуальных технологий для моделирования образовательного пространства и осуществления процесса обучения с использованием современных образовательных сервисов. Именно последние выдвигают новые требования к уровню подготовки современного педагога, на плечи которого ложиться ответственность за содержание будущей подготовки рабочих, служащих и специалистов среднего звена.

При конструировании содержания подготовки часто возникает необходимость обращения к более современным источникам информации, чем учебная литература и бумажные издания. В век информационно насыщенной образовательной среды все большее число специалистов находят ответы в неформальной среде форумов и блогов, где возможно получить консультацию специалистов разного уровня, в том числе 
разработчиков программного обеспечения, образовательных технологий или технологических процессов и систем. Наличие таких сетевых ресурсов имеет и ряд негативных последствий, связанных с ненадежностью и недостоверностью источников информации сетевого сообщества.

Кроме того, сам процесс приобретения новых знаний, умений и навыков, также подвергается модификации через включение в него информационных технологий, таких как сеть Интернет, когда появляется промежуточное звено (опосредованные технические изобретения) между источником информации и его приемником. Данное обстоятельство особенно остро влияет на образовательный процесс, вынуждая современных педагогов искать пути подготовки студентов к новой социальной и информационной действительности, а также способы устранения искажения данных, передаваемых по международной сети.

Также надежность информации, располагающейся в сети Интернет, часто не может быть подтверждена из-за реализации технологий web 2.0, которые предполагают свободу в пополнении данными ряда наиболее популярных в студенческой среде сервисов. Представленные требования говорят о необходимости не только информационной подготовки современных студентов, но и о формировании у них критического мышления, готовности эффективно и рационально отбирать информацию, оценивать ее надежность и достоверность, а также компетентно и оптимально ее применять.

Причем критическое мышление предполагает не только осознание содержания информации и проведение ее логического анализа, а что наиболее важно учет этических норм ее использования в своей профессиональной деятельности, тогда такое отношение может стать гарантом социальной защищенности и стабильности нового поколения.

Данные обстоятельства говорят о необходимости формирования критического отношения к информации и данным, поступающим из сети Интернет. Причем данное отношение должно быть сформировано через критическое мышление, которое представляется как особый тип сознания и некоторую интеллектуальную способность, характеризуется вдумчивым отношением к проблемам и вопросам профессиональной деятельности, учетом собственного опыта, умением использовать методы логического исследования и рассуждения.

По своей сути критическое мышление предполагает наличие некоторой исследовательской работы, как показано на рисунке 1, по анализу поступающих извне сведений и данных и определение их авторитетности, логичности и этической корректности, причем последнее как отмечает ряд исследователей связано с наличием этического фильтра, который бы позволил эффективно осуществлять критическую проверку норм и ценностей, заложенных в информационных сообщениях.

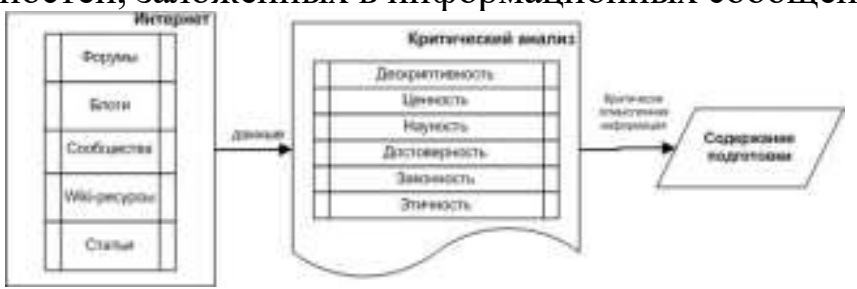

Рисунок 1 - Схема критического осмысления поступающей информации и ее трансформации в содержание подготовки

Развитие критического мышления будущих педагогов профессионального обучения возможно при выполнении комплексных заданий, контекст которых предполагает учет критериев корректности обучающей информации. Так, в Российском государственном профессионально-педагогическом университете при подготовке педагогов профессионального обучения в рамках дисциплины «Информационные технологии в образовании» студентом было предложено разработать собственный обучающий блог средствами облачного сервиса Google Blogger. Причем информацию, размещаемую в блоге, следовало находить только в сети Интернет в общедоступных источниках. Перед использованием информации обучающиеся должны были оценить уровень «авторитетности» данного источника, определить тип информационного содержания найденных или предоставленных сведений: их дескриптивность, ценность, научность, достоверность, законность и этичность. 
В процессе выполнения данного задания студенты не только освоили умения осуществления поиска информации в сети Интернет и представления его с использованием облачных сервисов, но и научились отделять факты от суждений, оценивать авторитетность источника информации по таким критериям, как научный и социальный статус, легитимность источников информации, и осознавать этическую значимость размещаемой информации и ее социальную и образовательную ценность.

Таким образом, развитие критического мышления является неотъемлемой часть компьютерной подготовки современного педагога профессионального обучения, позволяет ему стать активным участником формирования этического информационного фильтра современной молодежи. Одним из наиболее эффективных способов его формирования мы считаем подготовку содержания обучающего контента и осуществление критического анализа информации, размещаемой им в данном сетевом ресурсе, что способствует развитию собственного этического кодекса студента.

$$
\text { *** }
$$

1. Арсеньев К.С. К проблеме формирования критического мышления у студентов вуза // Образование и наука. 2011. №10 (89). С.68-82.

2. Баландина И.В. Принципы моделирования методической системы подготовки будущих учителей информатики к применению технологий компьютерной визуализации // Молодой ученый. 2011. №9. C. 198-201. URL http://moluch.ru/archive/32/3671/ (дата обращения: 03.02.2019).

3. Гузанов Б.Н., Федулова К.А. Проектно-модульное непрерывное междисциплинарное обучение в профессионально-педагогическом вузе //Современная высшая школа: инновационный аспект. 2017. Т 9. № 4. C. 34-44.

4. Федулова К.А. Особенности организации информационной подготовки студентов вуза на основе проектно-модульного междисциплинарного обучения // Наука. Информатизация. Технологии. Образование: материалы XI Междунар. науч.-практ. конф. Екатеринбург, 26 февраля-2 марта 2018 г. Екатеринбург: Изд-во ФГАОУ ВО «РГППУ». 2018. С. 396-401.

5. Оконская Н.К., Ермаков М.А. Специфика социально-экономических отношений информационного общества // Вестник ПНИПУ. Социально-экономические науки. 2017. №4. С.124-132.

6. Сергеева Т.Б. Профессиональная мобильность преподавателя высшей школы: проблемы исследования // Вестник ТОГУ. Педагогика и психология. 2013. №1(28). С. 243-259.

7. Гузанов Б.Н., Федулова М.А. Особенности транспрофессиональной инженерной подготовки в профессионально-педагогическом вузе // Профессиональное образование и рынок труда. 2019. №1. C. 66-70.

8. Гузанов Б.Н., Тарасюк О.В., Башкова С.А. Развитие профильно-специализированных компетенций в процессе отраслевой подготовки студен-тов профессионально-педагогического вуза // Европейский журнал социальных наук. 2016. №2. С. 239-245.

9. Glaser E.M. An Experiment in the Development of Critical Thinking. Teachers College, Columbia University, 1941.

\section{Кирюшина О.Н. \\ Развитие и эффективное использование научной информации как основа интеграции научного и образовательного пространства}

Таганрогский институт имени А.П. Чехова (филиал) ФГБОУ ВО «Ростовский государственный экономический университет (РИНХ)» (Россия, Таганрог)

doi: $10.18411 /$ scienceconf-05-2019-56

idsp: scienceconf-05-2019-56

\section{Аннотация}

Идея статьи - уточнение и прогнозирование развития ресурсов научного потенциала системы образования и их эффективное использование на всех этапах научной и образовательной деятельности. Постоянное пополнение системы научных знаний будет способствовать интеграции научного и образовательного пространства в решении задач совершенствования содержания образования и других педагогических проблем. 


\section{Abstract}

The idea of the article is to clarify and predict the development of scientific potential resources of the educational system and their effective use at all stages of scientific and educational activity. Constant replenishment of scientific knowledge system will help to integrate scientific and educational space in solving problems of education content improvement and other pedagogical problems.

Современная модернизация системы образования, ориентированная на развитие человеческого потенциала, как условие инновационного развития страны, предопределяет необходимость постоянного пополнения научных знаний, систематизации и выявления направлений их эффективного использования. Непрерывное развитие научной информации в образовании, как отображение общественных процессов и явлений, обеспечивается педагогической наукой, и, прежде всего, научно-исследовательской деятельностью.

Научно-исследовательская деятельность в образовании - процесс выработки новых и теоретическая систематизация научных знаний по педагогической и связанной с ней проблематике. Результаты научных, в т.ч. диссертационных исследований, отражающие проблемы педагогической действительности и способы их реализации, обеспечивают непосредственное расширение областей научных знаний - теоретических, методологических, методических, научно-исследовательского инструментария. Создание новых разработок способствует дальнейшему развитию научно-педагогической деятельности и ее интенсификации. Наряду с решением актуальных научных проблем в области образования и формированием научно-информационного ресурса, результат научно-исследовательской деятельности служит базой оценивания подготовки кадров высшей квалификации.

Научно-информационный ресурс - новые знания, идеи и др., как непосредственный продукт интеллектуальной деятельности академической науки и высшей школы, а кадровый - часть педагогической общественности, обладающая способностью создавать такой продукт, относятся к числу основных ресурсов научного потенциала системы образования. Зависимые во многом от состояния и результатов научно-исследовательской деятельности, они относятся к числу важнейших внутренних факторов системы образования, определяющих процесс ее модернизации.

Развитие основных ресурсов научного потенциала системы образования - процесс непрерывной выработки новых научных знаний по педагогической и связанной с ней проблематике, рост квалификации научных кадров, в том числе высшей квалификации, прежде всего, предполагает:

- наличие и активность деятельности научных школ;

— взаимодействие научных школ различной направленности в субъектах;

- обеспеченность условий воспроизводства кадров высшей квалификации;

- достаточность методического, технологического и информационного обеспечения обучающихся и исследователей;

— внедрение в образовательный процесс учебных курсов научноисследовательской подготовки специалистов;

— сформированность научно-информационной базы развития ресурсов научного потенциала системы образования разного уровня регионального, федерального;

- адекватную деятельность органов власти и управления в обеспечении условий целостного развития системы образования в стране.

Безусловно, актуализация непрерывного образования и использование кластерного подхода, обеспечивающего условия для координирования деятельности и поиска оптимальных путей управления развитием системы образования, вызывает необходимость достижения определенных локальных целей. Но в сложившихся условиях развития страны и реформирования образования актуально достижение комплекса целей, 
направленных на усиление единства процессов: подготовки высококвалифицированных специалистов; постоянного пополнения научных знаний на основе результатов научноисследовательской деятельности; эффективного использования информации в научной и образовательной деятельности.

Пополнение научно-информационного ресурса определяется состоянием научнопедагогической деятельности в стране и отдельных регионах, а его использование зависит от возможности доступа к полученным результатам и подготовленности их к применению на практике для решения актуальных задач модернизации системы образования. Значительный потенциал в реализации указанных задач, соответствующих требованиям современного образования, заложен в научной информации, получаемой на основе изучения, анализа и синтеза множества результатов научных исследований. Это обусловлено тем, что поскольку развитие системы образования основывается на новациях, полученных, как правило, в процессе научно-исследовательской деятельности, то характеристика ее результатов, имеющих теоретическую новизну и практическую значимость, отражает реальный процесс совершенствования образования в стране и регионах.

Обеспечить условия эффективного использования такой информации возможно с помощью объективной научно-информационной базы развития ресурсов научного потенциала. Основу ее создания составляет теоретическая систематизация результатов научно-исследовательской деятельности и представление научной информации в виде комплекса количественных показателей и структурно-количественных моделей $[1 ; 2]$. Объективные научные знания, характеризуя состояние педагогической науки и системы образования, способствуют адекватному выбору направлений развития ресурсов научного потенциала. Такая систематизированная информация может составлять основу принятия решений в управлении научно-педагогической деятельностью.

Научные знания о результатах научно-исследовательской деятельности, полученные на основе наукометрического исследования, являясь «питательной средой» научной и образовательной деятельности, должны внедряться в учебные программы всех видов и уровней образования.

Обновление содержания и технологий профессионально-педагогического образования определяется перспективными направлениями развития образовательной деятельности. В настоящее время достижение цели профессионально-педагогического образования - повышение интеллектуального и творческого потенциала обучающихся, вызывает перенос акцентов на воспитательную и развивающую функции, обеспечивающих духовное и нравственное развитие, высокую психологическую устойчивость и готовность специалистов к эффективной научно-творческой деятельности. Целостное становление личности будущего специалиста предполагает формирование базовых знаний достаточных для профессионально-педагогической и научноисследовательской деятельности. В процессе решения педагогических проблем, специалист, имея фундаментальные профессиональные знания, должен быть способен анализировать педагогические явления и события, и активно использовать полученные знания в различных видах профессиональной деятельности.

Указанные особенности подготовки специалистов отражают специфику компетентностного подхода. Реализация данной модели образования, как обеспечение возможности человека эффективно действовать в различных проблемных ситуациях, и условие развития интеллектуального потенциала людей, будет способствовать формированию ряда профессиональных качеств. Прежде всего, развитие способностей: самообразовательной деятельности, содействующей развитию профессиональной компетенции; теоретического мышления специалиста, ведущего к научному осмыслению объективной педагогической реальности; активного включения будущих педагогов в процесс формирования ценностных ориентаций в образовательной области; выработки системы педагогических ценностей и освоение навыков профессиональной 
коммуникации; использования различной научной информации для интерпретации фактов и явлений педагогической действительности.

Полученные знания и развитие различных способностей определяют формирование универсальных и профессиональных компетенций педагогов: правильное понимание и личностное принятие сущности современной гуманистической образовательной парадигмы; владение понятийным аппаратом педагогики и целостное видение педагогического процесса; умение объяснять и прогнозировать педагогические явления и процессы; наличие собственного опыта видения педагогических проблем; квалифицированное использование конкретно-научных и общенаучных методов в решении педагогических задач; развитая научно-исследовательская позиция в профессиональной деятельности.

Безусловно, содержание и технологии профессионально-педагогического образования, направленного на подготовку всех лиц, причастных к обучению и воспитанию подрастающих поколений, позволяют определить состояние и оценить перспективы развития всей системы образования. Поэтому эффективная реализация компетентностной модели образования возможна только при непрерывном комплексном развитии научных знаний, в т.ч. полученных в процессе теоретической систематизации результатов научно-исследовательской деятельности. Прежде всего, необходимо совершенствование: образовательных программ и содержания образования; условий подготовки и переподготовки педагогических кадров, формирование профессиональных знаний специалистов; системы управления педагогическим процессом, качеством образования и подготовкой выпускников; научного и учебно-методического обеспечения образовательной деятельности; дидактических условий и средств развития личности и др. компонентов, составляющих и определяющих деятельность образовательного пространства организаций.

Итак, прогноз возможного развития системы образования, прогрессивные идеи, рекомендации по улучшению организации образовательного процесса должны использоваться в системе подготовки педагогических кадров: от специалистов среднего звена системы образования, задействованных в этой сфере - до кадров высшей квалификации - педагогов-исследователей.

Объективная оценка реальных достижений в развитии научно-информационного ресурса весьма значима для кадров высшей квалификации - специалистов, генерирующих новые идеи и владеющих методологией и методами научных исследований. Обоснованные методологические подходы, модели изучения различных процессов и явлений в системе образования, усовершенствованный исследовательский инструментарий, характеристика современного научного потенциала системы образования и другая научная информация, полученная в процессе адекватного синтеза и структуризации результатов обобщения материалов научно-исследовательских работ, может являться ориентиром для исследователя в современном научном фонде педагогики.

Генерализация системы научных знаний обеспечивает возможность адекватного управления развитием системы образования, обращенного на усиление взаимосвязи этапов научно-исследовательской деятельности - постоянного пополнения ее результатов и их эффективного использования для подготовки специалистов, в т.ч. кадров высшей квалификации. Обобщенная научная информация, направленная на уточнение и прогнозирование процессов развития ресурсов научного потенциала, будет способствовать интеграции научного и образовательного пространства в решении многообразия педагогических проблем. Это важно для взаимодействия научных школ и центров регионов Российской Федерации, способных оказать влияние на повышение научного потенциала системы образования страны.

Таким образом, одной из задач системного решения проблем повышения интеллектуального и творческого потенциала обучающихся является непрерывное пополнение и эффективное использование новых научных знаний - теоретических 
положений, методологических подходов, практических рекомендаций, методов исследования и др. информации. Но не только создание, но и эффективное использование новых научных знаний - научно-информационного ресурса, является обязательным условием поступательного развития любой деятельности, в том числе и в области образования. Это возможно при усилении единства этапов научно-педагогической деятельности: подготовки педагогических кадров всех направлений; формирования фонда новых методологических и теоретических разработок и систематизированных научных знаний; внедрение в практику результатов исследований.

$$
* * *
$$

1. Кирюшина О.Н. Тенденции развития научно-информационного и кадрового ресурсов высшей школы / О.Н. Кирюшина // Мир науки, культуры, образования. Международный научный журнал. Горно-Алтайск. - 2017. - № 3. - С. $62-65$.

2. Кирюшина О.Н. Теоретические и практические аспекты наукометрического исследования научнопедагогической деятельности / О.Н. Кирюшина // Вестник Томского государственного университета. - 2018. - № 429. - С. 189-195.

\section{Ланкин С.В., Иванюк Ю.О. Метапредметный подход в обучении астрономии}

Благовещенский государственный педагогический университет (Россия, Благовещенск)

doi: 10.18411/scienceconf-05-2019-57

idsp: scienceconf-05-2019-57

Аннотация
В настоящее время прослеживается тенденция к снижению познавательной
деятельности у значительной части учащихся при изучении предметов
естественнонаучого цикла, в частности астрономии. Проблема в образовании
заключается не в передаче объема знаний, а в том, чтобы научить учиться. В данной
статье авторами рассматривается метапредметный подход на уроках астрономии с целью
активизировать творческую деятельность учащихся. Метапредметность позволяет создать
целостную картину мира в сознании ученика, объединив учебные дисциплины из
различных областей (физика, математика, химия, биология, география и т.д.). Игровые
моменты на уроках помогают ребятам осознать возможность применения приобретенных
знаний в смежных областях науки, синтезировать явления, заново выдвинуть свои идеи,
повторить открытие. Такая методика позволяет по новому организовать понимание. На
таких уроках астрономии происходит формирование личности ответственной,
самостоятельной, творческой, а также происходит углубление знаний по предмету.
Ключевые слова: астрономия, метапредметный подход, игровые моменты,
познавательная активность, метапредметный проект.

Abstract

Currently, there is a tendency to a decrease in cognitive activity among a significant part of students in the study of the subjects of the natural science cycle, in particular astronomy. The problem in education is not to transfer the amount of knowledge, but to learn how to learn. In this article, the authors consider the meta-subject approach in astronomy lessons with the aim of activating the creative activity of students. Meta-subjectness allows you to create a holistic picture of the world in the mind of a student by combining academic disciplines from various fields (physics, mathematics, chemistry, biology, geography, etc.). Game moments in the classroom help the children to realize the possibility of applying acquired knowledge in related fields of science, synthesize phenomena, re-put forward their ideas, repeat the discovery. This technique allows for a new organization of understanding. At such astronomy lessons, a responsible, independent, creative personality is formed, and the subject matter is deepened.

Keywords: astronomy, met subject approach, game moments, cognitive activity, met subject project. 
Как и большинство современных наук, астрономия в наши дни отличается стремительным ростом. Это объясняется не только тем, что освоение космоса беспредельно расширило границы нашего познания о Вселенной, но и тем, что очень давно (более 150 лет назад) началось содружество между астрономией и физикой, химией, биологией. Союз оказался чрезвычайно полезным для всех наук. В результате астрономия из науки в основном математической превратилась в науку универсальную, конечной целью которой стало изучение физико-химических свойств космических тел и самого космического пространства. В свою очередь физика, химия, биология, радиосвязь и другие науки получили развитие, благодаря астрономии - гигантской лаборатории, в которой эксперимент ведется природой в масштабах, пока еще не осуществимых на земле.

Астрономия и ее методы познания имеют огромное значение в жизни человечества. Нет таких отраслей хозяйства и направлений науки, где не использовались бы астрономические технологии: измерение точного времени, составление географических карт, прогноз погоды, предсказывание магнитных бурь и морских приливов, проблемы навигации, обнаружение полезных ископаемых - пожалуй, всего не перечислить, где бы сегодня астрономия не нашла применение.

Благодаря своим достижениям, средствам массовой информации, астрономия получила известность и вновь вернулась в общеобразовательные учебные заведения разных ступеней образования. Ее эвристическое значение и воспитательное действие на человека любого возраста чувствуется ежедневно. Поэтому не удивляет стремление как можно раньше приобщить учеников начальных классов к астрономическим знаниям. С другой стороны, обучение астрономии требует больших усилий для учителей из-за отсутствия метапредметной связи учебных дисциплин, единой трактовки научных понятий, обще методических требований к процессу обучения.

Анализ интегрированных курсов («Окружающий мир», «Природоведение», «Физика и астрономия», «Химия и астрономия», «География и астрономия») показал, что школьный курс астрономии не должен быть уменьшенным курсом, излагаться не поверхностно, а с опорой на знания учащихся по математике, физике, химии, биологии, географии, истории и др. Его место на вершине пирамиды школьных знаний, как курса завершающего, не только физико-математического образования, но и их философского и экологического образований, нравственного и эстетического воспитания. Следует отметить, что разрабатываемая концепция астрономического образования в общеобразовательной школе предусматривает: 1) постепенное формирование основных понятий астрономии и космонавтики на протяжении всех лет учебной деятельности учащихся в школе; 2) само обучение астрономии должно строиться на основе достижений психологии и педагогики. проблемы.

В настоящей статье мы делаем попытку проанализировать эти актуальные

В настоящее время понятия «метапредмет», «метапредметное обучение», «метапредметный подход», «метапредметность» приобретают особую популярность. Это вполне понятно, т.к. метапредметность заложена в основу новых стандартов. Метапредметный подход предполагает, что школьник (студент) не только овладевает системой знаний, но и осваивает универсальные способы учебных действий и с их помощью самостоятельно добывает информацию об окружающем мире. Сегодня важно не столько дать учащимся количество знаний, сколько научить его учиться [14].

Метапредметный подход в образовании, в частности астрономии, разрабатывается для того, чтобы решить проблему разобщенности, оторванности друг от друга разных учебных дисциплин. В природе физические, химические, биологические процессы взаимосвязаны, в учебных же заведениях все эти явления изучаются раздельно, тем самым их природные связи разрывают. Метапредметы - учебные дисциплины, предполагающие работу с материалом нескольких учебных предметов сразу. Это новая образовательная форма, которая выстраивается поверх традиционных учебных дисциплин. В основе лежит мыследеятельностный тип интеграции учебного материала и принцип рефлексивного отношения к базисным организованностям мышления: «знание», «знак», «проблема», «задача» [5, 6, 14]. 
Дидактическая модель учебного предмета «Астрономия» состоит из двух блоков: основной и процессуальный. Для астрономии основным компонентом являются научные знания, т.к. только на их основе, и с их помощью возможна реализация всех других ее задач. Процессуальный блок включает комплекс вспомогательных знаний (межнаучные, логические, методологические, межпредметные, историко-научные, оценочные и др.), способы деятельности, формы организации процесса обучения (лабораторные работы, практикумы, наблюдения, домашний эксперимент и др.) $[2,7,9]$.

В основе метапредметного подхода находится понимание того, что главное, чему надо учить школьников, - это творческое мышление. Метапредметный подход обеспечивает переход от существующей практики дробления знаний на предметы к целостному образному восприятию мира.

Обеспечение взаимосвязи преподавания астрономии, физики, химии есть ряд нерешенных вопросов, в частности, не устранено полностью некоторое дублирование учебного материала (молекулярно-кинетическое строение вещества, спектральный анализ, тепловое излучение, строение атома, ядерные реакции, физическое поле, теория относительности, законы движения планет, космические скорости и т.д.). Для ликвидации дублирования материала учителя астрономии должны знать программы, содержание родственных предметов. При составлении поурочных планов нужно учитывать не только предыдущую подготовку учащихся, но и указывать, какой материал, где и как его добыть.

Связь между преподаванием астрономии, математикой, физикой, химией, биологией в основном понятийная. Добиться для них полного временного согласования в учебном процессе очень трудно (например, уравнение движение планет, содержание периодического закона Д.И. Менделеева, фотонная структура света, химические действия света, спектры). Курс астрономии $[1,4,8,10,11]$ насыщен сведениями о физике планет, о свойствах материи за пределами Земли, что делает астрономию тесно связанной с физикой.

Методическая работа позволяет определить следующую структуру осуществления метапредметности на уроках астрономии: 1) уроки с привлечением некоторых знаний учащихся из других учебных предметов; 2) наблюдения и экспериментальные опыты; 3) обобщающие уроки; 4) решение нетрадиционных задач; 5) проведение мониторинга метапредметных результатов; 6) участие в работе олимпиад; 7) организационнодеятельностные игры; 8) турниры способностей; 9) проекты.

Для реализации поставленных целей используем материалы из учебников, задачников по астрономии $[1-4,8,10-13]$, электронные учебники, энциклопедии фирм: «1С», «Дрофа», «Кирилл и Мефодий», «Мир вокруг нас».

В качестве примера приведем следующие задачи:

1. Измерьте самодельным эклиметром высоту над горизонтом Полярной звезды и нескольких ярких известных звезд. Проанализируйте результат.

2. При помощи школьного астрономического календаря и подвижной карты звездного неба найдите вечером на небе главные созвездия и планеты. Зарисуйте их положения. Повторите наблюдения через 1, 2, 3 месяца. Объясните результаты.

3. Какие наблюдения доказывают, что в годичном движении Земли ось ее вращения не изменяет своего направления в пространстве?

4. Можно ли наблюдать Венеру утром на западе, а вечером на востоке? Проведите опыт и объясните его.

5. Как определить широту местности по Полярной звезде?

6. В какое время года линейная скорость движения Земли вокруг Солнца наибольшая (наименьшая) и почему?

7. Видимый угловой диаметр Солнца равен 30'. Найти расстояние от Земли до Солнца, если радиус Солнца равен 695000 км.

8. Почему карманные часы в роли компаса дают неточные показания?

9. Почему затмения Луны повторяются через 18 лет?

10. Что произойдет с космонавтом в открытом космосе, если нарушится герметичность скафандра?

В заключении следует отметить, что в условиях новых стандартов образования учитель должен уметь организовывать деятельность учащихся таким образом, чтобы 
создавались условия как для формирования универсальных учебных действий, так и самих предметных и метапредметных компетенций обучающихся.

$$
* * *
$$

1. Бакулин П.И., Кононович Э.В., Мороз В.И. Курс общей астрономии. - М.: Наука, 1966. - 527 с.

2. Воронцов-Вельяминов Б.А. Методика преподавания астрономии. - М.: Просвещение, 1985. - 240 с.

3. Воронцов-Вельяминов Б.А. Сборник задач по астрономии: Пособие для учащихся. - М.: Просвещение, 1980.- 56 с.

4. Воронцов-Вельяминов Б.А., Страут Е.К. Астрономия. Базовый уровень. - М.: Дрофа, 2018. - 238 с.

5. Гнитецкая Т.Н., Ковальчук Н.Н., Резник Б.Л. О метапредметности и физике // Школа будущего, 2018. - № 1. - C. 109-121.

6. Гнитецкая Т.Н., Шутко Ю.Е., Иванова Е.Б., Ковальчук Н.Н. Иерархические связи и естественнонаучная картина мира // Философия образования, 2015. - № 5. - С. 49-58.

7. Горев П.М., Лунеева О.Л. Межпредметные проекты учащихся средней школы: учебнометодическое пособие. - Киров: ВГУ, 2014. - 58 с.

8. Кондакова Е.В., Чаругин В.М. Астрономия. 10-11 классы. Тетрадь-практикум. - М.: Просвещение, 2018. - 32 c.

9. Ланина И.Я. Не уроком единым. Развитие интереса к физике. - М.: Просвещение, 2002. - 223 с.

10. Левитан Е.П. Астрономия. - М.: Просвещение, 2018. - 240 с.

11. Майлс Л., Смит А. Астрономия и космос. - М.: Изд-во Росмэн, 2002.-98c.

12. Перельман Я.И. Занимательная астрономия. -СПб.: СЗКЭД, 2017. - 224 с.

13. Рябоволов Г.И., Дадашева Н.Р., Самойленко П.И. Сборник дидактических заданий по физике. - М.: Высш. шк., 1990. - 512 с.

14. Хуторской А.В. Метапредметный подход в обучении: научно-методическое пособие. - М.: Изд-во «Эйдос», 2016. - 80 с.

\title{
Belaya N.A. ${ }^{1}$, Rechitskaya E.G. ${ }^{2}$ \\ Model of conditions for the formation of speech communication children with hearing impairment
}

\author{
${ }^{1}$ Istrinsky boarding school \\ (Russia, Istra) \\ ${ }^{2}$ Moscow Pedagogical State University \\ (Russia, Moscow)
}

doi: 10.18411/scienceconf-05-2019-58

idsp: scienceconf-05-2019-58

The acquisition of language is directly connected with the social education of the individual child with hearing loss. The level of speech development of a child with hearing impairment affects the degree of knowledge of their native language and the ability to improve the skills necessary for school (S.A. Zykov, L.P. Noskova). Training of the hearing impaired is associated with the presence of positive prerequisites for the independent accumulation of speech material and the possibility of independent mastery of speech communication (R.M. Boskis, K.G. Korovin).

The role of speech communication for the development of children with hearing impairment is in the formation of their mental activity, enrichment of the dictionary, the ability to organize joint productive activities and play, in the formation of interpersonal relations, knowledge of each other and further socialization.

Conducted by us (N.A. Belaya, E.G. Rechitskaya, 2016) the study of speech communication of preschool children with hearing impairment allowed to identify and characterize its components, namely: children's knowledges about communication, communication skills, speech and non-speech means of communication), communicative qualities of the person (sociability, activity, initiative, tact, empathy [1]. The results indicate the need for special (special) construction of correctional and pedagogical work on the development of speech communication of preschoolers with hearing impairment, students in different conditions, including inclusive. Let us refer to V.I. Lubovsky, who stressed that wherever a child with disabilities is trained - in a special institution or in conditions of integration - it should be special training [6]. 
The entire educational process should be aimed at overcoming speech underdevelopment and the formation of speech as a means of communication and thinking, which should be reflected in the goals and objectives, as well as in the planned results in each area of activity indicated in the new educational standard.

In the task of improving the quality of educational process the main thing is the identification, justification and verification of the conditions for ensuring the success of sociocommunicative development of preschool children with hearing impairment in the system of their training and education and educational evaluation of its components $[1,5,10,12]$.

Analyzing the concept of «condition» from the standpoint of philosophy, psychology, pedagogy, we can distinguish several common definitions. For example, this concept is characterized as:

- the totality of relations, States necessary for the existence of a thing or phenomenon;

- external and internal circumstances contributing to or impeding the action of development factors;

- rules established in any area of life and activity;

- the environment in which anything happens.

In addition, the concept of «condition» is presented in the context of the category of «development», which is mediated by the objects of material and spiritual culture of society and historically conditioned realities of human existence (subject and natural world, sign systems, social space, surrounding nature, etc.), and is used to describe the phenomenon of «human mental development» (A.N. Leontiev, S.L. Rubinshtein, L.S. Vygotsky, etc.).

More often, the concept of «condition» is interpreted more widely and it includes the causes, factors of development, technology, methods, means of training, education and development, management support (V.I. Zagvyazinsky, A.F. Zakirova, etc.). For any activity, including educational, invariants is the set of groups of terms: motivation, personnel, organizational, legal, material-technical, scientific-methodical, financial and information conditions (A.M. Novikov). However, in each case or pedagogical system, these groups of conditions will have their own specifics.

In this regard, the conditions that affect the quality, intensity and effectiveness of pedagogical processes (training, education, development) can be called pedagogical conditions, a distinctive feature of which is that they include structural components of pedagogical processes: goals, principles, content, methods, forms, means, monitoring. In the theory and practice of pedagogy several variants of pedagogical conditions are considered: organizational and pedagogical, didactic conditions, psychological and pedagogical.

Organizational and pedagogical conditions are a set of content, methods, forms, means of an integral pedagogical process aimed at achieving the goals of pedagogical activity and ensuring the successful solution of educational tasks (V.A. Belikov, E.I. Kozyreva, S.N. Pavlov, A.V. Sverchkov, etc.). Didactic conditions-a set of material possibilities of training and education, organizational forms, on the one hand, and on the other - the circumstances of interaction of subjects aimed at the development and functioning of the pedagogical process from a management perspective. Didactic conditions, as a rule, are associated with the presence of such circumstances, prerequisites, which take into account the existing conditions of training and provides ways to transform these conditions to achieve learning goals, built and used elements of content, methods (techniques) and organizational forms of training, taking into account the principles of optimization. The implementation of these conditions ensures the effectiveness of educational activities of both teachers and students. (S.V. Volkova, V.I. Loginova, M.V. Rutkovskaya, G.I. Shchukina).

Psychological and pedagogical conditions are designed to provide certain pedagogical measures to influence the development of the personality of the subjects of the pedagogical process, contributing to the effectiveness of the educational process (N.I. Zhuravskaya, A.V. Krugliy, A.V. Lysenko, A.O. Malykhin, etc.). This type of conditions has such characteristics as: a set of educational and material-spatial environment; focus on the development of the personality of the subjects of the pedagogical system; the ability to transform the processes of development, education and training; taking into account the structure of the transformed personal characteristics of the subject of the pedagogical process.

Summarizing, we note that the above-refined pedagogical conditions can be called as general pedagogical conditions that reflect a set of internal and external circumstances affecting 
the development, education and training of a person, can accelerate or slow down these pedagogical processes, affect their dynamics and final results.

In the system of preschool education pedagogical conditions include the organization and conduct of classes, regime moments; zonal distribution of the group room; joint activities «adult - child», «child - child»; subject-developing environment [2]. Subject-developing environment a space that promotes the development of all types of children's activities (communication, play, movement, work, design, drawing), correction of deviations of higher mental functions and the formation of the child's personality. It includes a number of basic components necessary for the full-fledged physical, social and communicative, cognitive, artistic and aesthetic development of children (natural environments and objects, cultural landscapes, sports and recreational facilities, subject-playing environment, musical and theatrical environment, subject-developing environment, etc.) [4]. The content of the subject-developing environment is associated with the age of the child and the leading activity in the preschool period. In addition, the content of the subject-developing environment should meet the needs of both current and future development of the child, meet his individual abilities. It should be noted that the content of the environment will become specific depending on the category of children with disabilities and children with disabilities.

For students with disabilities and children with disabilities in the organization and implementation of the educational process is necessary to create and implement special conditions, which include:

- use of special educational programs and methods of training and education, special textbooks, teaching AIDS and didactic materials, special technical means of teaching collective and individual use, assistive and communicative information technologies;

- provision of services of an assistant, tutor (assistant), providing students with the necessary technical assistance;

- group and individual remedial classes;

- providing access to the buildings of organizations engaged in educational activities,

- other conditions are possible, without which it is impossible or difficult to master educational programs for students with disabilities [13].

Along with the general pedagogical and special conditions of education, upbringing and development of preschool children with hearing impairment due to the peculiarities of their speech-thinking activity, emotional-volitional sphere and special educational needs in the system of special and inclusive education, it is necessary to create and implement specific conditions for this category of children.

The specific conditions of the organization of educational and correctional work with preschoolers with hearing impairment include the following:

- formation of children's need for speech communication and motivated speech communication with children in the process of different types of children's activities;

- support for all manifestations of the child's speech, whatever the level of his speech development, and the motivation for the active use of speech;

- control of children's speech by adults;

- compliance with the unified requirements to the speech of adults;

- create auditory-verbal environment;

- use and development of residual hearing;

- conducting remedial studies $[2,3]$.

Our researches (E.G. Rechitskaya, N.A. Belaya, E.S. Kulakova, S.A. Zourabian, Y.V. Gaidova, O.V. Troshkina) show the necessity of improving the motivational and emotional component indicative values activities for children with hearing impairment, active dip them in creative reproductive activity with the provision of the right of choice, the importance to enhance verbal communication of inclusion in the joint distributed activity, from preschool age, which is convincingly manifested in the independent role-playing game and in shaping interpersonal relations $[1,7-11]$. 
When organizing correctional and pedagogical work on the formation of speech communication of children with hearing impairment in an educational institution, a model of conditions that would ensure its development should be implemented (Fig. 1).

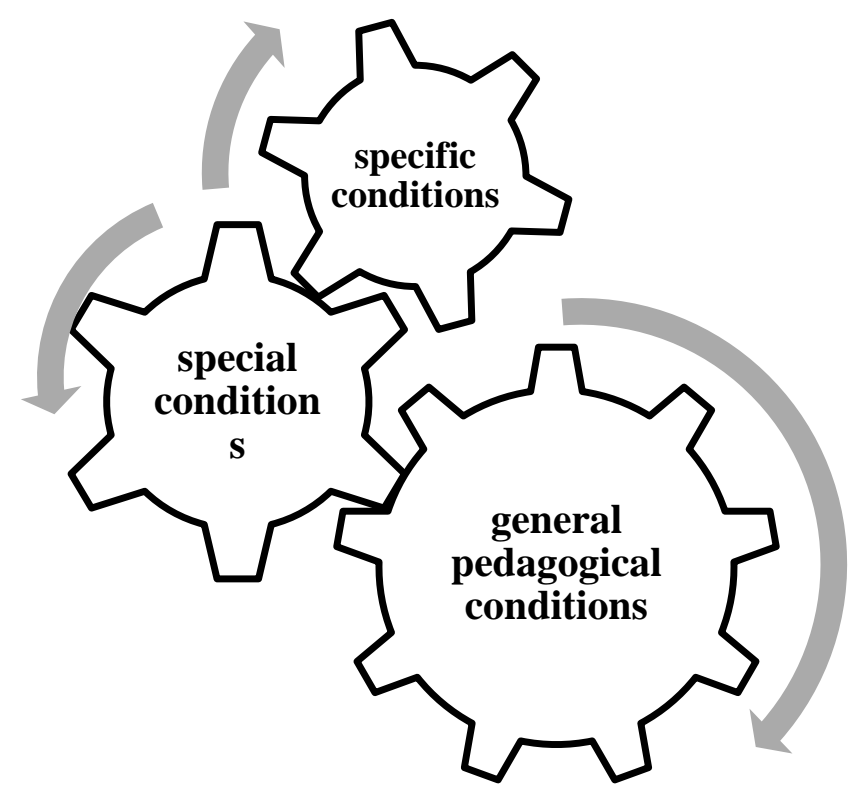

Fig 1. Model conditions for the formation of speech communication of children with hearing impairment

As can be seen in their Fig. 1, the model of conditions for the formation of speech communication of children with hearing impairment is a set of diverse and at the same time functionally and organizationally similar external and internal circumstances that make up a single whole.

The proposed model can be implemented in a special and inclusive education of children with hearing impairments with the active participation of all participants in the educational process (administration, teachers, educators, teachers-defectologists, teachers-psychologists, tutors, parents).

Age and psychophysiological features of formation of speech activity of the child with hearing impairment allow to direct his education and training in the direction of initiative productive cooperation through dialogue communication. The main thing is not to ignore the motives of children's communication, even if expressed with the help of elementary natural gestures and, perhaps, sign language, but to use the child's readiness to enter into dialogue as the initial form of speech communication, to feel the initiative coming from children. At the same time, it is important to follow a certain sequence: first of all, to teach dialogue and the ability to conduct dialogue, then monologue as the highest form of speech activity. This keeps and develops the motivation of communication, improves the quality of speech activity of children. The dialogue itself should be based on clarification and understanding of different points of view (№What do you think ...»), «you agree with me or with Olya»), finding a common way of action in joint activities (E.G. Rechitskaya, 2017, etc.).

Implementation of the model of conditions for the formation of speech communication of children with hearing impairment is achieved by:

- impact on the consciousness, feelings, behavior of the child. This involves the formation of ideas about communication as a special kind of human activity, the development of arbitrary manifestation of communicative skills and communicative qualities of the person, an adequate choice of speech and non-speech means of communication;

- purposeful pedagogical influence on the development of speech communication and activity of the child's personality;

- close interaction of all participants of the educational and correctional process and their continuity in the system of educational and correctional activities;

- formation of personal qualities through the organization and conduct of special correctional, educational and training activities, special forms of joint activities, in which the tasks of social and personal development are solved; 
- taking into account the special educational needs of preschool children with hearing impairment for the optimal implementation of current and potential opportunities, including cognitive and motivational.

1. Belaya N.A. Psihologo-pedagogcheskiye usloviya razvitiya rechevogo obshsceniya slaboslyshashscih doshkolnikov : diss... . kan. ped. nauk. - M.: 2016. - 186 s.

2. Golovchic L.A. Doshkol'naya surdopedagogika: Vospitanie i obuchenie doshkol'nikov s narusheniyami sluha. - M.: VLADOS, 2001. - 319 s.

3. Goncharova E.L., Kukushkina O.I. Rebenok s osobymi obrazovatel'nymi potrebnostyami//Al'manah Instituta korrekcionnoj pedagogiki RAO. - 2002.- Vyp. №5. - URL: http://almanah.ikprao.ru/articles/almanah-5/rebenok-s-osobymi-obrazovatelnymi-potrebnostjami (data obrashcheniya: 01.03.2019 g.).

4. Evtushenko I.N. Predmetno-razvivayushchaya sreda v doshkol'nom uchrezhdenii i ee diagnostika // Nachal'naya shkola plyus do i posle. - 2008. - № 4. - S. 33-36.

5. Kobrina L.M., Himenkova E.S. Formirovanie rechevoj kommunikacii detej s kohlearnymi implantami v usloviyah special'noj shkoly-internata / Special'noe obrazovanie : materialy XIII mezhdunarodnoj nauchnoprakticheskoj konferencii. 2017. - S. 16-26.

6. Lubovskij V.I. Osobye obrazovatel'nye potrebnosti // Psihologicheskaya nauka i obrazovanie psyedu.ru. 2013. - №5. URL: http://psyedu.ru/journal/2013/5/Lubovskiy.phtml (data obrashcheniya: 12.03.2019 g.).

7. Rechickaya E.G. Korrekcionno-pedagogicheskaya rabota po formirovaniyu uchebnoj deyatel'nosti mladshih shkol'nikov s narusheniem sluha. - M.: VLADOS, 2017.

8. Rechickaya E.G., Gajdova YU.V. Special'naya psihologiya i korrekcionnaya pedagogika: mezhlichnostnye otnosheniya mladshih shkol'nikov s narusheniem sluha. - M.: YUrajt, 2018. - 138 s.

9. Rechickaya E.G., Zurob'yan S.A. Uchebnoe sotrudnichestvo v sisteme obucheniya detej s narusheniyami sluha. - M.: MPGU, 2018. - 192 s.

10. Rechickaya E.G., Kulakova E.V. Gotovnost' slaboslyshashchih detej doshkol'nogo vozrasta k obucheniyu v shkole. - M.: VLADOS, 2014. - 199 s.

11. Rechickaya E.G., Troshkina O.V. Model' korrekcionno-razvivayushchej raboty po formirovaniyu kommunikativno-rechevoj kompetentnosti doshkol'nikov $\mathrm{s}$ narusheniem sluha $\mathrm{v}$ usloviyah igrovoj deyatel'nosti // Nauka i shkola. - 2018. - №3. - S.95-100.

12. Turutina M.A., Denisova O.A., Kazanskaya V.L. Pedagogicheskaya ocenka razvitiya rechevoj kommunikacii u shkol'nikov srednej stupeni obrazovaniya s narusheniem sluha / Special'noe obrazovanie: materialy XIV mezhdunarodnoj nauchno-prakticheskoj konferencii. 2018. - S. 21-24.

13. Federal'nyj zakon «Ob obrazovanii v Rossijskoj Federacii» ot 29.12.2012 № 273-FZ (red. ot 25.12.2018).

\section{Kozlova N.G. \\ Sociocultural environment and its modeling in a secondary school}

School Kuzminki

(Russia, Moscow)

doi: 10.18411/scienceconf-05-2019-59

idsp: scienceconf-05-2019-59

\section{Abstract}

In this article numerous approaches to defining the sociocultural environment are studied. The views of the classics of the Russian pedagogy as well as the modern researchers are shown. The definitions of the sociocultural environment from fundamental works and dessertations are being analysed and the author of the article after the deep analysis provides her own definition. The siciocultural environment of a teaching organization and the surroundings of the student are looked at through the prism of personality and qualitative teaching. The relevance of the interest to this issue is underlined. The author provides the personal experience in creating a sociocultural environment in a secondary school.

Key words: sociocultural environment, personality, education quality, operational, competence approach.

The problem of necessity of creating in an educational establishment the sociocultural environment which is aimed at the overall development and upbringing of the student's 
personality is nowadays relevant though rather difficult in the conditions of the educational establishments focusing on the qualitative educational system in which the competence approach is being realized.

The phenomenon of the sociocultural environment became the object of the active scientists' study only at the end of the $20^{\text {th }}$ century and the unified definition of this term by this time has not been formulated. In this respect it is particularly important to comprehend in detail the concept of the environment, the most famous visions and approaches which have predetermined its modern understanding.

In the history of the Russian pedagogical idea development in this direction a significant role has been played by the classics of the Russian pedagogics like V.A. Sukhomlinsky and A.S. Makarenko. So in the works of V.A. Sukhomlinsky the statement about sociocultural environment being the combination of educating the personality means (material and spiritual activity), its conditions (beauty and interaction) and subjects' position (attitude to material and activity spheres and to each other) was concisely formulated [9]. The author of the "Pedagogical Poem" A.S. Makarenko defined the key mechanism of teaching team shaping (sociocultural environment) as the development of responsible dependence relationships. He based his idea on the fact that the establishment of the personality itself is connected with his/her natural ability to perceive the connection with other people and to subordinate his/her life to definite responsibilities. This process in his opinion is the personality's entering into responsible dependence relationships. He wrote: "In order to imagine this problem more clearly, let's look at the team in action. In this team the dependences are rather difficult, each separate personality must coordinate his/her personal intentions with the intentions of the others: first with the aim of the team, second with his/her initial team - the nearest group, must coordinate so that the personal goals do not become antagonistic in relation to the common goals" [6, p. 193].

The general trend in research of sociocultural environment can be traced in the fundamental works, theses and articles in which, first of all, it is noted that the sociocultural environment is multifunctional, multifactored and in its common field it seizes not only professional or everyday, informative or educational space but it penetrates the whole activity of the personality and shapes a definite lifestyle. Herewith, the term "sociocultural environment" itself presupposes two aspects, in the context of which we consider the student's personality establishment: social and cultural [2, p. 44-45].

In terms of this logic the sociocultural environment is being defined as a special socially organized cultural phenomenon in which social and cultural processes are tightly interconnected and interdependent, are developing in the frames of the general idea and influence the activity of the social parties in creation and assimilation of spiritual values and social guidelines [1]. Or it is understood as a particular, directly given to each child social space, by means of which he/she actively incorporates into the cultural relations in the community [8]. Attempts to define sociocultural environment as a specific area are being undertaken [5, p.91.]. However, there is a significant difference between them: in the concept of area unlike in environment, involvement of the person into it is not implied [4, p. 18], meanwhile the environment forms the man and the man forms his/her environment. Moreover, the environment presupposes not only the presence of the person but also mutual influence and interaction of the surroundings with the subject. To add to this, particularly people organize, create the educational environment and affect it in a certain way [7, p.176.]

Significant in the context of the subject matter of sociocultural environment seem the study of pedagogical orientation in which special attention is paid to the possibilities of affecting the personality of the student through teaching particular subjects, creating programs designed in a special way which are connected with shaping the sociocultural environment. In this respect sociocultural educational environment is defined as the area of common vital activity of the teacher and the student which provide the choice of the values, the meaning of life, the environment of the vital activity, ways of cultural self-realisation, and functions on the principles 
of socio-economic determination, cultural causation, information selectiveness and paradigmatics [3], [2, p. 45].

For our research it is also important to note that the modern person is influenced not only by the nearest surroundings (the culture of the family or the social group to which they belong), but also the whole atmosphere of the community life, the way of existence in the world society, its indirect interaction through the books and multimedia meanswith the cultures of different countries and eras. One of the basis of structural analysis can serve the division of all the components of the sociocultural environment into material and spiritual.

Let us look into the specifics of the sociocultural environment of the school which first of all fulfills the teaching and educational functions. In this respect we will note its following characteristics: operational (the presence of mutual activity of the subjects), communicative (appearance of different connections and relations), reflective, value-semantic (vcommon goals, norms, values, meanings of communication and interaction).

So, we can infer that sociocultural environment is a complex of outside conditions of person's stay which with the qualitative work transform into the inner personality's values.

In our school "School Kuzminki" (Moscow, Russia) we have gained substantial experience in sociocultural environment modeling with the help of various work forms and teaching and educational events. In this article we would like to describe our traditional events which create the sociocultural environment of our school. These events have been hold for many years.

Amateur performances - is one of the components of the sociocultural environment and it is being widely developed in "School Kuzminki". Children of different age groups from the kindergarten and school prepare performances, dances, songs both in native and foreign languages, poems timed to various important dates: Teacher's Day, Elderly Person's Day, Mother's Day, New Year, Christmas, Motherland Defender Day, Women's Day, Victory Day, Meeting with the veterans. The concerts are always bright and professionally carried out. Of course the children need an adult help which they get from the teacher-organiser, teacher of music and world cultures, and kindergarten teacher. Moreover, our children prepare the festive programme and perform for the elderly people and children with disabilities. These events teach children to communicate with people of different ages, social position, they teach children to be tolerant, supportive and caring.

In our school we yearly conduct the competition "The Student of the Year". During the year the form teacher sets points in the electronic system created by our system managers specially for our school. The points are for the outward appearance (school uniform), for participation in the Olympiads, for active involvement in the life of the class and the school, for the excellent marks at school during the week. For bad marks during the week the teacher deducts the points. At the end of the school year the points for any 10 weeks are counted and 10 best students in each class are distinguished. Out of these 10 students 2 absolute winners in each class are distinguished. At the end of the school year 10 best students with the greatest number of points are awarded with certificates at the grand meeting and their parents are handed with thank you letters. The absolute winners are invited together with their parents to the festival "The Pride of Our School", where the certificates and the letters are given by the headmaster.

In the year of 2011 in School Kuzminki the student government "Solar System" was started. In this system the students themselves elect the President of the Solar System as well as one representative into the government from each class. Each class is a Solar City and the children are divided into departments: juridical, project, informational, organizational, and statistical - and during the school year each department is responsible for a certain part of the class's life. Every week the meetings are held and the information about the next period is given and the results are announced. For different deeds the students get stars which they stick to their "star sky". At the end of the school year the results are summed up and the best star class is distinguished. The "Solar System" lets unite the children of the whole class and of the whole parallel classes and even of the whole school to become the children of sole planet, sole universe. 
Every February our school conducts Art Festival for which the theme and the regulations are defined at the beginning of the school year. The children prepare a performance on this theme: literary, dancing and singing. This year the theme of the Festival was The Theatrical performances of the world due to the year of the theatre and the previous themes were "May there always be peace" and "How the motherland begins". The performances are assessed in parallels (e.g. all the $7^{\text {th }}$ forms). This festival helps not only nurture a sense of beauty but also active civic stand and the feeling of patriotism.

The competition Historical Reading also helps develop the feeling of patriotism. The representatives from each class prepare a presentation about the war heroes and deliver it in certain costumes to the judges. The judges are the teachers of art and culture, music, teachersorganizers. The best school representations then go to district and municipal level.

The Days of Health and Sport Festivals organized at the school during weekends also contribute to nurturing the active civic stand. The children come for these events with pleasure and bring their parents and take part in relay race, marathons, contests and competitions.

A special attention at our school is paid to the school leavers homecoming night. The school leavers of different years are invited for the meeting with the headmaster and the teachers. It is always pleasant for the students that they are remembered and waited in the walls of their native school. The teachers always listen with interest to the stories about the life of the school leavers and tell them the news from the school life.

At the end of the school year we arrange the last bell ringing event for the school leavers of Year 9 and Year 11. The school leavers prepare a festive programme for the teachers, the teachers make farewell speeches on the eve of the exams. It is notable that in School Kuzminki not only the teachers who have been working with these students from Year 1 to Year 11 (secondary school teachers and primary school teachers) are invited to this festival, but also the teachers who already do not work at the school for some reason.

Participation in public events: our students actively participate in different public events like Collect plastic lids, or Make a postcard for the New Year for the elderly people from the retirement homes, or Present veterans and elderly people with flowers and postcards for the Victory Day, or Make a souvenir ffor elderly people for Elderly Person's Day.

It is important to point out that at our school children of different social levels as well as children of different nationalities study. The teachers nurture in the children the feeling of tolerance and create the atmosphere of amicability and comfortable psychological climate.

All the events in creating the sociocultural environment in School Kuzminki described provide the children with great social experience, teach communicating with people of different professions, age groups and rules of conduct and serve as a powerful upbringing factor.

As we can see from the events described in School Kuzminki the most favorable conditions for nurturing patriotism, active civic stand, tolerance and patience are created. The children are attached to the sense of beauty and the cultural life of the school as well as of the city and the country.

$$
* * *
$$

1. Arnoldov A.I. Введение в культурологию. - М.: Народная академия культуры и общечеловеческих ценностей, 1993. - $352 \mathrm{pp}$.

2. Burdukovskaya Е.А. Социокультурная среда вуза как педагогический фактор личностного становления студента. Дисс.Канд.пед.наук. Благовещенск, 2004. - 201 pp., p. 44-45.

3. Ignatova V.V. Педагогические факторы духовно-творческого становления личности в процессе социализации и условия их реализации: Дис... д-ра пед. наук / Челябинский государственный университет (ЧелГУ), 2001.- 365 рр.

4. Krivykh S.V. Соотношение понятий «Среда» и «Пространство» в социокультурном и образовательном аспектах // Известия АлтГУ. 2010. №1-2. - Р. 18.

5. Krylova N.B. Социокультурная среда // Новые ценности образования: Тезаурус... -Вып. 1. - М., 1995.- p.91.

6. Makarenko A.S. Педагогические сочинения. В 8-ми томах. Т.4. - М.: Педагогика, 1986. - 399 рр., p. 193. 
7. Nenakhova E.N. Теоретико-методологические подходы к формированию социокультурного пространства образовательного учреждения // Известия РГПУ им. А.И. Герцена. 2010. №128. p.176.

8. Nitssche F. Сочинения: В 2 т. / Ф. Ницше. - М., 1990. - Т.2 - 830 pp.

9. Sukhomlinskiy V.A. Избранные педагогические сочинения: В 3-х т. Т.З/Сост.О.С.Богданова, В.3.Смаль.-М.: Педагогика, 1981.-640 pp. 


\section{РАЗДЕЛ ХVІІ. ПСИХОЛОГИЯ}

\section{Магомедова А.Н., Бутаев Р.P. \\ Изучение своеобразия эмоциональной сферы детей с интеллектуальной недостаточностью}

ФСДО ДГПУ

doi: $10.18411 /$ scienceconf-05-2019-60

idsp: scienceconf-05-2019-60

Необходимость изучения эмоциональной сферы детей с интеллектуальной обусловлена тем, что ее нарушение является одной из основных причин, по которой дети с нарушениями интеллекта неуживчивы в семье и не могут приспособиться к требованиям детских учреждений.

Длительное проявление неадекватных по характеру и силе эмоций, сопровождающиеся иногда аффективными вспышками или психотическими эпизодами, часто приводит к формиравованию девиантного поведения ((Ковалев В.В. 1995, Григоренко Е.Л. 996 и др.). Когнитивные и поведенческие отклонения продолжают сохранять у $85 \%$ подростков и почти у $70 \%$ взрослых с интеллектуальной недостаточностью. В подростковом возрасте у этих детей в силу преобладания ситуативных эмоций развивается тяга к алкоголю и другим психоактивным веществам, что становится причиной аддиктивного и девиантного поведения.

Однако все исследования, посвященные детям с интеллектуальной недостаточностью, позволяют сделать следующие выводы, касающиеся когнитивной и эмоциональной сферы данной формы дизонтогенеза:

1. Никакие, даже самые грубые нарушения психической деятельности не меняют ее отражательной функции. Отражение объективной реальности может быть неточным, недостаточно глубоким, но оно остается адекватным.

2. Несмотря на то, что интеллектуальная недостаточность может рассматриваться как «особый способ генеза психики»ей свойственно все то же самое, что свойственно для развития вообще, т. е. формирование новообразований, направленность, необратимость и т.д.

Это позволило сделать вывод о том, что подбор максимально соответствующих форм, методов и правильная организация деятельности по формированию эмоциональной сферы у детей с интеллектуальной недостаточностью, дает стойкий положительный результат.

Главное направление развития эмоциональной сферы у детей с интеллектуальной недостаточностью - это способность управлять эмоциями, т.е. произвольность поведения. Эта способность является ключевой в процессе социальной адаптации умственно отсталых детей.

Этим и была обусловлена проблема нашей работы -выявить особенности эмоциональной сферы детей с интеллектуальной недостаточностью, а так же пути и условия ее коррекции.

Решение данной проблемы имеет важное значение для психологопедагогической практики. Поиск путей формирования эмоциональной сферы наиболее ценен именно для детского возраста. Раннее выявление проблем в эмоциональной сфере и их коррекция должны быть ориентированы на детский возраст, когда достаточно велики компенсаторные возможности психики, и есть возможность не допустить формирования стойких эмоциональных проблем, затрудняющих социальную адаптацию детей с интеллектуальной недостаточностью.

Исходя из проблемы, мы поставили следующие задачи:

1) рассмотреть особенности эмоциональной сферы у детей с нарушениями интеллекта; 
2) проанализировать особенности коррекции эмоциональной сферы у детей с нарушениями интеллекта;

3) разработать систему психолого-педагогических методов коррекции эмоциональной сферы у детей с нарушениями интеллекта.

Экспериментальное исследование по проблеме проводилось с учащимися школы IIX вида г.Махачкалы. Они составили основную (экспериментальную) группу. Контрольная выборка участников эксперимента сформирована из детей с нормальным интеллектом, никогда не обращавшихся за психологической помощью, и не имеющих жалоб на неадекватное поведение со стороны педагогов и родителей.

Для решения выдвинутой нами проблемы, нами была уточнена диагностика детей с интеллектуальной недостаточностью (медицинская, педагогическая, психологическая). С помощью клинико-биографического метода нами изучены анамнестические данные: семейные психосоциальные условия, влияние вертикальных и горизонтальных стрессов.

В психодиагностическом исследовании использованы следующие методики:

- Опросник J.Swanson, диагностирующий особенности поведения.

- Проективная методика «Рисунок семьи» ( ВолковБ.С., ВолковаН.В., 1997) и «Оценочная шкала эмоциональных проявлений ребенка» (Головей Л.А., Рыбалко Е.Ф., 2001), позволившая исследовать особенности личности, уровень самооценки и межличностных коммуникаций у детей с интеллектуальной недостаточностью.

На основе данных медицинского, психологического и педагогического обследования нами выявлены особенности эмоциональной сферы у детей с нарушениями интеллекта и особенности их проявлений. Здесь полученные нами данные совпали с представленными в литературе данными. Всех детей можно разделить на три основные группы. Для детей первой групnы характерны вялые, заторможенные стереотипные эмоциональные реакции. Дети оказываются как бы безразличными к воздействующим на них раздражителям.

У детей, относящихся ко второй группе реакции чрезмерно бурные, по своей силе не соответствующие вызвавшим причинам, а в ряде случаев просто неадекватные.

У детей третьей груnпы не прослеживаются грубые нарушения эмоциональной сферы, хотя в отдельных случаях наблюдается отклонения и не всегда объяснимые поступки.

В ходе эксперимента мы отметили, что немаловажную роль в неблагополучии эмоциональной сферы детей с нарушениями интеллекта играют социальные условия. Внешнее социальное окружение часто выступает причиной патогенных эмоциональноповеденческих особенностей, которые провоцируют сложности в эмоциональном развитии детей с нарушениями интеллекта и выступают как фактор риска нарушения эмоциональных процессов.

Результаты исследования влияния внешнего социального окружения на эмоциональную сферу детей с нарушениями интеллекта мы представляем в табл. 1

Таблий 1

Распространенность сочиальных факторов, неблагоприятно влияющих на эмочиональную сферу у детей с нарушениями интеллекта

\begin{tabular}{|c|c|c|c|c|}
\hline Социальные факторы риска & \multicolumn{2}{|c|}{ Основная группа } & \multicolumn{2}{|c|}{ Контрольная группа } \\
\hline & $\begin{array}{c}\text { Абсолютное } \\
\text { число }\end{array}$ & $\%$ & $\begin{array}{c}\text { Абсолютное } \\
\text { число }\end{array}$ & $\%$ \\
\hline 1. Неполная семья & 30 & 54,5 & & \\
2.Развод родителей & 8 & 14,5 & 4 & 8,1 \\
3.Низкий материальный уровень & 17 & 31,4 & 1 & 1,8 \\
\hline Итого: & 55 & 100 & 5 & 9,9 \\
\hline Уровень взаимоотношений в семье: & 15 & 27,3 & 31 & 56,4 \\
1. «Положительный» & 30 & 54,5 & 24 & 43,6 \\
\hline
\end{tabular}




\begin{tabular}{|c|c|c|c|c|}
\hline 3. «Отрицательный» & 10 & 18,2 & & \\
\hline Итого: & 55 & 100 & 55 & 100 \\
\hline
\end{tabular}

Как видно из таблицы, семейный микроклимат, внутрисемейные конфликты, сверхавторитет родителей крайне негативно сказываются на эмоциональном состоянии детей с нарушениями интеллекта.

Проведенный нами анализ коррекции эмоциональной сферы у детей $\mathrm{c}$ нарушениями интеллекта позволил нам сделать следующий вывод: работа по данному направлению строится, прежде всего, через развитие основных врожденных эмоций, которые у этой категории детей относительно сохранны.

Выбор методов психолого-педагогической коррекции эмоциональной сферы у детей с нарушениями интеллекта зависит от степени тяжести и спектра этих нарушений. Предложенные нами направления деятельности достаточно универсальны, на наш взгляд, и могут варьироваться в зависимости от индивидуальных потребностей ребенка:

- коррекция тревожности и формирование уверенности в себе;

- коррекция положительных эмоций

- коррекция страхов

- коррекция поведенческих дефектов.

Учитывая возраст детей, основными средствами коррекции в нашей системе являются: детская игра, элементы психогимнастики, специальные приемы неигрового типа.

Подобная работа не только способствует улучшению эмоционального состояния у детей с нарушениями интеллекта, но и способствует их общему жизненному благополучию.

$$
* * *
$$

1. Забранная С.Д. Психолого-педагогическая диагностика умственного развития детей. / С.Д. Забранная - М., 1993.

2. Кулагина И.Ю. Возрастная психология (Развитие ребенка от рождения до 17 лет) - Учебное пособие. -5-е изд/ И.Ю. Кулагина - М.: Изд-во УРАО, 1999.

3. Основы специальной психологии [Текст] / Л. В. Кузнецов Л.И. Переслени, Л. И. Солнцева и др.; Под ред. Л. В. Кузнецовой. - М., 2002.

4. Кто они, дети с отклонениями в развитии? [Текст] / В.Г. Петрова, И.В. Белякова - М., 1998.

5. С.Я. Рубинштейн Психология умственно отсталого школьника.[Текст] / С.Я. Рубинштейн - М., 1986.

\title{
Торебаев Б.П., Бектурсунова А.К., Ботабаев Н.Е., Ханазарова К.О. Функциональное значение цвета
}

\author{
Южно-Казахстанский государственный \\ университет имени М. Ауэзова \\ (Казахстан, Шымкент)
}

doi: 10.18411/scienceconf-05-2019-61

idsp: scienceconf-05-2019-61

Нас окружает огромное количество цветов, но, ни один из них по силе эмоционального воздействия не сравнится красным. Этот цвет является согревающего огня, а потому многие древние культуры наделяли красный цвет магическими свойствами. Восточные мудрецы считали красный цвет символом Солнца. Они были уверены, что красный способен растопить снег, даже и лед, так как этот цвет обладает уникальным свойством, которое может аккумулировать тепло внутри себя. И у казахов красный цвет соотносили с огнем, культ которого существовал в Великой степи с древности повсеместно. 
Многие японцы и в наше время верят, что красные ткани, особенно алые согревают и несут положительную энергию. Поэтому ХидеджиКудо, владелец магазина одежды в Токио начал производить хлопчатобумажное нижнее белье красного цвета. «Люди вырывали у нас его из рук» - говорит он. А в Аргентине покупатели внимательно рассматривает упаковки с пищевыми продуктами в поисках разноцветных точек. Если на упаковке стоит зеленая точка, значит, безупречна во всех отношениях: в нем нет ни ГМО, ни транс-жиров, ни пальмовых масел. Если хотя бы один неоднозначный компонент присутствует, то на упаковке ставится желтая точка. А красная точка означает сигнал тревоги. Таким образом, сигналы может выражаться не только звуком или жестом, но и цветом. Языком вспомогательного общения являются знаки дорожного движения. По международному соглашению красный цвет служит предвестником опасности, красный сигнал у светофора - знак запрета: этот цвет закроет нам дорогу. Открывает дорогу зеленый цвет светофора.

У животных есть свои средства общения, но упустынного хамелеона Африки не такая каку приматов и стадных, у него особый «язык»- цветовой.Всем известно, когда возникает необходимость, они меняет цвет кожи, например холодное время, темнеет, чтобы поглощать тепло, а жаркое время дня светлеет, чтобы отражать свет, но не каждый знает, что с помощью цвета хамелеоныи общаются между собой. Оказывается, эти экзотические ящерицы, чтобы спросить, где можно хорошо обедать, или объясниться даме в любви, или сделать вызов своему сопернику каждый раз меняет свой цвет. Однако нет сомнений в том, что переработка сигналов человеком и животными не просто резко различается, но она принципиально иная. Каждое мышление есть переработка сигналов, но не каждая переработка сигналов есть мышление.

Спортивная форма красного цвета ассоциируется с силой, страстью и агрессией. Согласно исследованиям ученых, красный цвет может повысить шанс на победу в спортивных состязаниях, а фиолетовый цвет увеличивает выносливость, поэтому спортсмены ценят этих цветов, Есть и другие интересные факты: цвет формы спортсменов влияет на решения судей; цвет текста может влиять на принятие решений; утверждения зеленого цвета может вызывать согласие.

Синяя лампа в комнате или стен подобных цветов повышает трудовой энтузиазм. Воздействие этих цветов положительно сказывается увеличению концентрации внимания и остроте зрения. Особенно благоприятными для глаз являются зеленый цвет и его оттенки - они помогают на длительный период сохранять высокую работоспособность и хороши для использования их там, где работа человека связана с умственным трудом или зрительным напряжением. Неслучайно в библиотеках раньше часто ставили лампы с зелеными абажурами, считая что, для рабочего кабинета или мастерской творческого человека может подойти зеленая гамма[2].

Английский бригадный генерал сэр Гарри БернеттЛимсден который командовал корпусом разведчиков во время подавления индийского восстания заметил, что покрытая глиной пылью военная форма совершенно сливается с местностью, делая воинов невидимыми. Он приказал ослепительно-белую униформу, которую не выдерживало условий Индии покрасить в цвет хаки. Эффект превзошел все ожидания. Его солдаты в такой форме буквально растворялись в окружающем пейзаже. К тому же на такой расцветке грязь была совсем не видна [3].

Таким образом, каждый цвет вызывает у человека цепь ассоциаций. Они влияют не только на его психологическое и эмоциональное состояние, но и на физиологическое. Еще древние знахари подметили этот феномен и с успехом применяли на практике цветолечение. Удалось восстановить часть сведений о функциональных значениях цветов в народной медицине: у народов Центральной Азии, в частности у таджиков самым распространенным цветом в старину были черный и белый, действующий против сглаза. Желтый цвет защищал от желтухи, синий цвет спасал от коклюша. 
Итак, при изучении проблемы цвета представляют большой интерес его эмоциональное свойство. Эмоциональная активность цвета и ее влияние на людей подмечены еще в древности, но природа этого явления до сих пор до конца не выяснена. Цвет - это сильнодействующее средство. По крайней мере, так считают врачи. «Доказано, что одно лишь созерцание насыщенного цвета учащает пульс и повышает кровяное давление», - говорит доктор Пенни Стэнвей, автор книги «Свет жизни: цвет лечения». В последнее время на Западе увлеклись новой психологической практикой умиротворяющим наблюдением за пернатыми. Орнитотерапия уже доказала свою эффективность не только лечений птичьим пением, но и цветом. По мнению психологов, наиболее благоприятное воздействие на человеческую психику оказывает созерцание розового фламинго. Таким образом, в изучении этих непростых проблем цвета могут оказать существенную помощь его психологические особенности.

$$
* * *
$$

1. Расул Шыбынтай. Меж бандой и сарабандой. Газета «ЭК» №33 от 22 февраля 2019 г.

2. Борижан Торебаев. Орнамент и цвет в дизайне текстиля, Монография. Изд.: LAP LAMBERT Academic Publishing - 2017/ Германия /.

3. Найденова Н., Трубецкова И. «Мода, цвет, стиль» М.: «Эксмо» 2012. 


\section{Dля заметок}




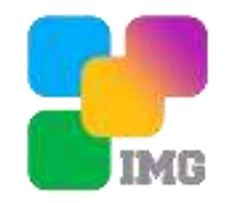

Scientific publication

Scientific achievements of the third millennium

The collection of scientific papers of the materials IX International scientific conference "Scientific achievements of the third millennium"

\section{Part 4}

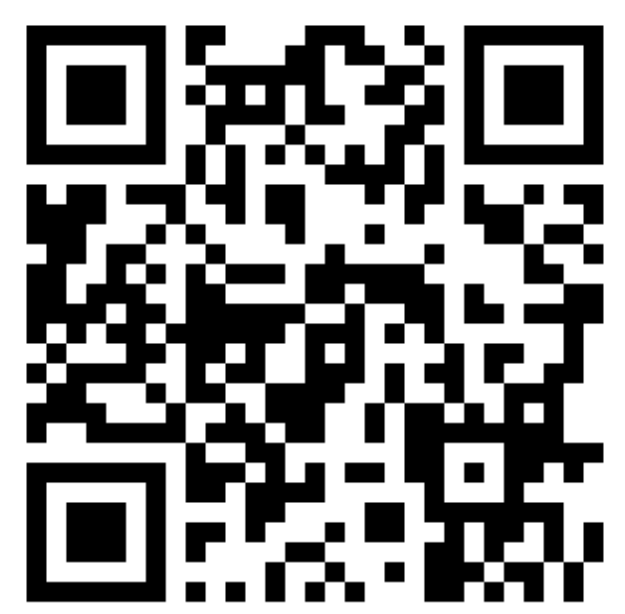

SPLN 001-000001-0467-SA

Signed print 13.07.2019. Circulation 400 copies.

Format.60x841/16.

Paper, offset. Printing operative.

Printed by SIC "LJournal"

Editor Chief: Ivanov Vladislav 